\title{
CORROSION STUDIES FOR A FUSED SALT-LIQUID METAL EXTRACTION PROCESS FOR THE LIQUID METAL FUEL REACTOR
}

\author{
H. Susskind, F.B. Hill, L. Green, S. Kalish, L.E. Kukacka, \\ W.E. MCNULTY, AND E. WIRSING, JR.
}

June 30, 1960

\footnotetext{
BROOKHAVEN NATIONAL LABORATORY Associated Universities, Inc. under contract with the United States Atomic Energy Commission
} 


\title{
CORROSION STUDIES FOR A FUSED SALT-LIQUID METAL EXTRACTION PROCESS FOR THE LIQUID METAL FUEL REACTOR*
}

\author{
H. Susskind, F.B. Hill, L. Green, S. Kalish, L.E. Kukacka, \\ W.E. MCNULTY, AND E. WIRSING, JR.
}

June 30, 1960

*A condensed version of this report appeared in Chemical Engineering Progress 56, 57-63 (1960).

$$
\begin{aligned}
& \text { BROOKHAVEN NATIONAL LABORATORY } \\
& \text { Upton, N.Y. }
\end{aligned}
$$




\section{E G A L N O T I C E}

This report was prepared as an account of Government sponsored work. Neither the United States, nor the Commission, nor any person acting on behalf of the Commission:

A. Makes any warranty or representation, expressed or implied, with respect to the accuracy, completeness, or usefulness of the information contained in this report, or that the use of any information, apparatus, method, or process disclosed in this report may not infringe privately owned rights; or

B. Assumes any liabilities with respect to the use of, or for damages resulting from the use of any information, apparatus, method, or process disclosed in this report.

As used in the above, "person acting on behalf of the Commission" includes any employee or contractor of the Commission, or employee of such contractor, to the extent that such employee or contractor of the Commission, or employee of such contractor prepares, disseminates, or provides access to, any information pursuant to his employment or contract with the Commission, or his employment with such contractor.

\section{PRINTED IN USA}

\section{PRICE $\$ 1.00$}

Available from the Office of Technical Services, Department of Commerce Washington 25, D.C. 


\begin{abstract}
Corrosion screening tests have been carried out on potential materials of construction for use in a fused salt - liquid metal extraction process plant. The work was done in support of the Liquid Metal Fuel Reactor fuel processing project. The corrodents of interest were $\mathrm{NaCl}-\mathrm{KCl}-\mathrm{MgCl}_{2}$ eutectic, $\mathrm{LiCl}-\mathrm{KCl}$ eutectic, Bi-U fuel, and $\mathrm{BiCl}_{3}$, either separately or in various combinations. Screening tests to determine the resistance of a wide range of commercial alloys to these corrodents were performed in static and tilting-furnace capsules. Some ceramic materials were also tested in static capsules. Larger-scale tests of metallic materials were conducted in thermal convection loops and in a forced circulation loop. Some of these tests were conducted isothermally at $500^{\circ} \mathrm{C}$, and others were performed under $40^{\circ}$ to $50^{\circ} \mathrm{C}$ temperature differences at roughly the same temperature level. On the basis of metallographic examination of exposed test tabs and chemical analyses of corrodents, it was found that the binary and ternary eutectics by themselves produced little attack on any of the materials tested. A wide variety of materials including 1020 mild steel, $2^{1 / 4} \mathrm{Cr}-1 \mathrm{Mo}$ alloy steel, types 304 (ELC), 310, 316, 347, 430, and 446 stainless steel, 16-1 Croloy, Inconel, Hastelloy $\mathrm{C}$, Inor-8, Mo, and $\mathrm{Ta}$ is, therefore, available for further study. Corrosion by the ternary salt - fuel system was characteristic of that produced by the fuel alone. Alloys such as 1020 mild steel, and $1 \frac{1 / 4}{\mathrm{Cr}}-1 / 2 \mathrm{Mo}$ and $2^{1 / 4} \mathrm{Cr}-1$ Mo alloy steel, which are resistant to fuel, therefore, would be likely choices at present for container materials. $\mathrm{BiCl}_{3}$ produced extensive attack on ternary salt - fuel containers when the fuel contained insufficient concentrations of oxidizable solutes. Au and $\mathrm{Al}_{2} \mathrm{O}_{3}$ were the only materials not attacked by $\mathrm{BiCl}_{3}$ in ternary salt alone.
\end{abstract}




\section{CONTENTS}

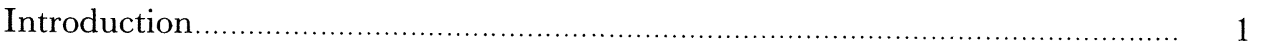

Experimental Program...................................................................... 2

Preparation and Handling of Corrodents.......................................... 3

Test Specimen Preparation ............................................................. 3

Specimen Examination and Corrodent Analysis................................ 3

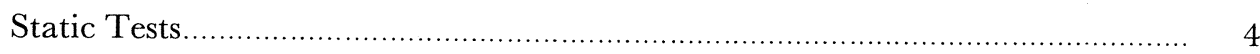

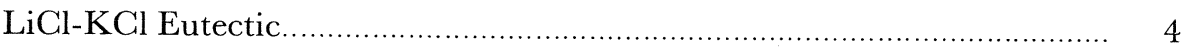

$\mathrm{NaCl}-\mathrm{KCl}-\mathrm{MgCl}_{2}$ Eutectic ....................................................... 4

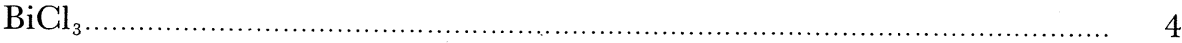

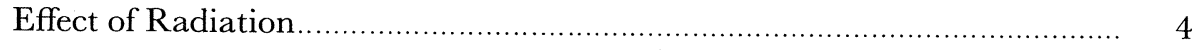

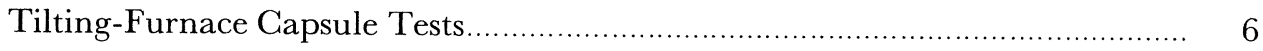

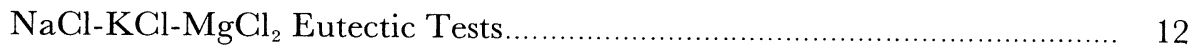

Bi-U Fuel/Ternary Eutectic Tests................................................. 13

Ternary Eutectic/ $\mathrm{BiCl}_{3}$ and $\mathrm{Bi}-\mathrm{U}$ Fuel/Ternary Eutectic/BiCl ${ }_{3}$ Tests...... 16

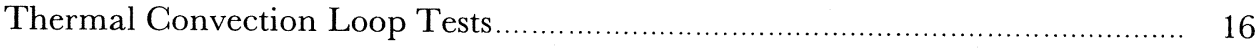

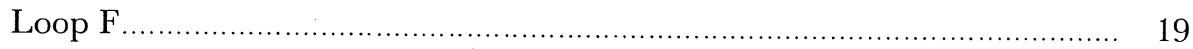

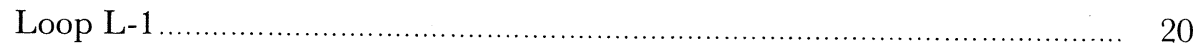

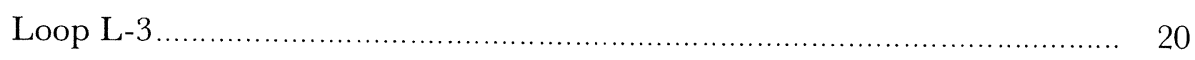

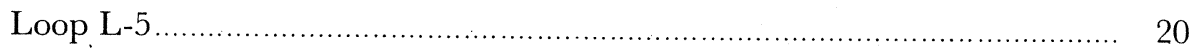




\section{CONTENTS}

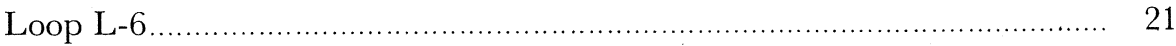

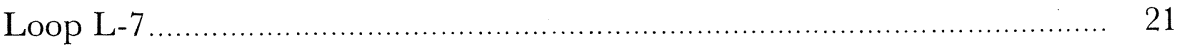

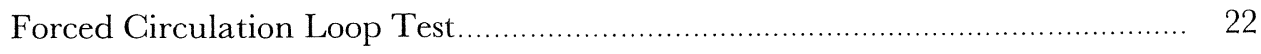

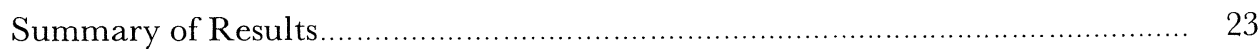

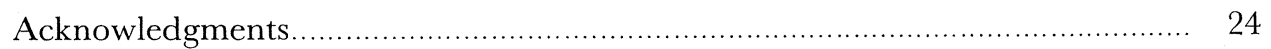

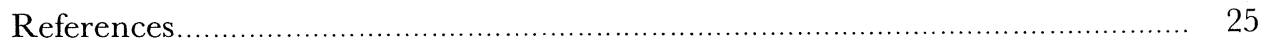

Appendix A. Mill Test Reports of Metallic Materials Tested............................ 27

Appendix B. Chemical Analysis of Bi-U Fuel and Fused Salt Solutions............ 28

Appendix C. Axial Temperature Profile of Tilting-Furnace Capsule ……........ 29

Appendix D. Crimping Forces Used in Tilting-Furnace Capsule Preparation.... 30

Appendix E. Test Data and Results

for Tilting-Furnace Capsule Screening Tests............................................. 31

Corrodent: NaCl-KGl- $\mathrm{MgCl}_{2}$ Eutectic ...................................... 31

Welded Tab Specimens; Corrodent: NaCl-KCl-MgCl${ }_{2}$ Eutectic.... 33

Corrodent: Bi-U Fuel and Ternary Eutectic.................................. 34

Corrodent: $\mathrm{NaCl}-\mathrm{KCl}-\mathrm{MgCl}_{2}$ Eutectic Plus 4.76\% $\mathrm{BiCl}_{3} \ldots \ldots \ldots \ldots \ldots . \quad 38$

Corrodent: Bi-U Fuel/Ternary Eutectic Plus 4.76\% $\mathrm{BiCl}_{3} \ldots \ldots \ldots \ldots . .39$

Appendix F. Results of Thermal Convection and

Forced Convection Loop Corrosion Product Analyses 


\section{CORROSION STUDIES FOR A FUSED SALT-LIQUID METAL EXTRACTION PROCESS FOR THE LIQUID METAL FUEL REACTOR}

\section{INTRODUCTION}

A typical fuel for use in a Liquid Metal Fuel Reactor (LMFR) is a dilute solution of $\mathrm{U}, \mathrm{Mg}$, and $\mathrm{Zr}$ in $\mathrm{Bi}$. By means of a process which has been under development at Brookhaven National Laboratory, ${ }^{1}$ an important group of fission products may be continuously removed from the fuel by contacting it with a mixture of fused chlorides at $450^{\circ}$ to $500^{\circ} \mathrm{C}$. A small portion of the fuel stream is continuously fed to an extraction column (No. 1 in Figure 1) in which it is contacted with the fused eutectic mixture of $\mathrm{NaCl}, \mathrm{KCl}$, and $\mathrm{MgCl}_{2}$ (30, 20, and 50 mole \%, respectively; m.p. $396^{\circ} \mathrm{C}$ ). A small amount of the strong oxidant $\mathrm{BiCl}_{3}$ is added to the influent salt. Those fission products (identified as FPS in Figure 1) whose chlorides are more stable than $\mathrm{MgCl}_{2}$ and some $\mathrm{U}$ are oxidized into the salt in this column. Make-up $\mathrm{Mg}$ is added to the fuel before it is returned to the reactor. $\mathrm{U}$ in the salt leaving column 1 is recovered first by reduction into a solution of $\mathrm{Mg}$ in $\mathrm{Bi}$ in column 2. It is then oxidized into the incoming salt by $\mathrm{BiCl}_{3}$ in column 3 .

It is apparent that the corrosion environment in such a processing plant would vary considerably from one point to another. Certain vessels and piping would be exposed to highly oxidizing $\mathrm{BiCl}_{3}$ solutions, and others would be exposed only to the relatively inert $\mathrm{NaCl}-\mathrm{KCl}-\mathrm{MgCl}_{2}$ eutectic. Some components would be exposed to the molten fuel alone and others to the ternary salt alone. Con-

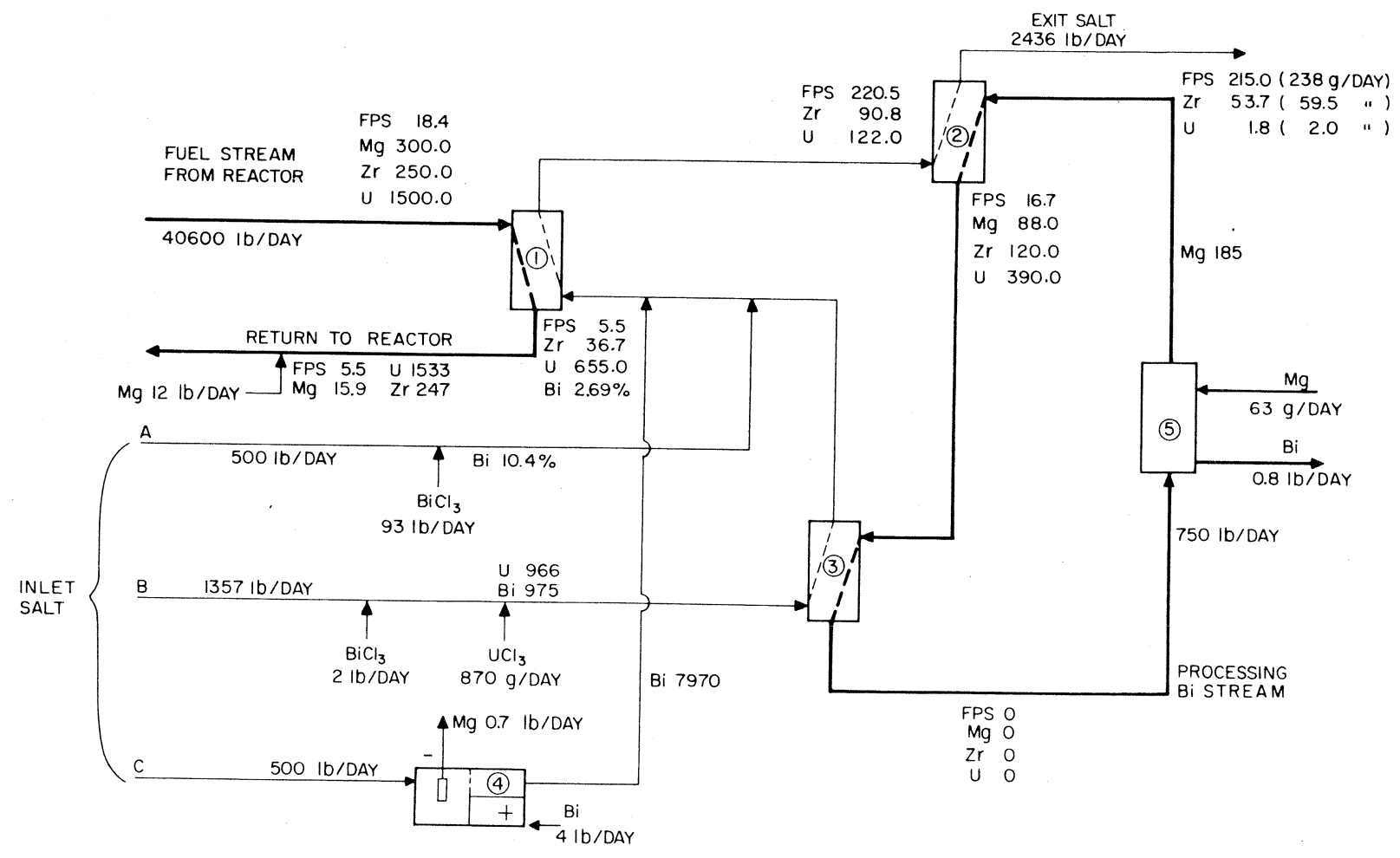

Figure 1. Process flow sheet for LMFR fused salt extraction of fission products from Bi-U fuel. ${ }^{1}$ FPS denotes fission products. Concentrations are in ppm unless otherwise indicated. 
tacting vessels would contain both fuel and salt in two-phase flow. Fission product decay heat might give rise to temperature gradients resulting in mass transfer corrosion.

The purpose of the work described in this paper was to perform corrosion screening tests on materials of construction for an LMFR fuel processing plant. The testing program was not completed because of phase-out of work on fluid-fuel reactor concepts. ${ }^{2}$ The principal results of the program are reported here. Most of the work was in support of a process design based on the NaCl-KCl$\mathrm{MgCl}_{2}$ eutectic. ${ }^{1}$ Some work is reported on the LiCl-KCl eutectic ( 41 mole $\% \mathrm{KCl}$, m.p. $351^{\circ} \mathrm{G}$ ) which was the salt first used in fuel processing studies at BNL. ${ }^{3}$

\section{Previous Work}

Corrosion by the liquid metal fuel itself was the subject of a separate program at BNL, ${ }^{4}$ and hence no fuel corrosion tests per se were performed in the work described here. In the fuel corrosion program, most experience was obtained with a fuel composed of $1000 \mathrm{ppm} \mathrm{U}, 350 \mathrm{ppm} \mathrm{Mg}$, and 250 to $350 \mathrm{ppm} \mathrm{Zr}$ in $\mathrm{Bi}$. $\mathrm{Mg}$ was present as a getter to protect $\mathrm{U}$ from oxidation. $\mathrm{Zr}$ is believed to form a protective film of $\mathrm{ZrN}$ or $\mathrm{ZrC}$ on the container surface by reaction with $\mathrm{N}$ or $\mathrm{C}$ from the container material. This fuel has been circulated for many thousands of hours without causing serious corrosion in thermal convection loops and forced convection loops made of low-chrome alloy steels $\left(1^{1 / 4} \mathrm{Cr}-1 / 2 \mathrm{Mo}\right.$ and $2^{1 / 4} \mathrm{Cr}-1 \mathrm{Mo}$ ) with temperature differences of up to $100^{\circ} \mathrm{C}$ and at maximum temperatures of $550^{\circ} \mathrm{C}$. Although the various aspects of the corrosion resistance of these steels have not yet been fully studied, one of the following would most likely be specified at present as the fuel container material for any proposed reactor experiment: $1 \frac{11 / 4}{\mathrm{Cr}}-1 / 2 \mathrm{Mo}, 2^{1 / 4} \mathrm{Cr}-1 \mathrm{Mo}$, or 1020 mild steel.

Fused salts have been used industrially for many years, in pyrometallurgical refining processes and in heat transfer and metals heat treating applications. Yet few corrosion data have been published, especially on fused chloride systems. One of the few existing pertinent papers describes an extensive investigation of materials for molten chloride heat treating baths. ${ }^{5}$ In this work it was found that intergranular penetration along carbide networks was far more important than general solution of metal. High-nickel, low-chrome alloys were found to offer the most resistance to corrosion in 50-hr static tests at $870^{\circ} \mathrm{C}$.

With few data available for interpretation, theories of fused salt corrosion are largely speculative. Although substantial solubility of metals in their own salts has been noted, ${ }^{6}$ corrosion by salts of metals different from the container material is thought to occur generally as a result of electrochemical action rather than by physical solution. Effects commonly associated with physical solution, such as mass transfer corrosion, are nevertheless possible if, in the corrosion mechanism, a temperature-dependent electrochemical equilibrium is involved.

No previous work seems to have been reported on corrosion by a two-phase liquid metal - fused salt system.

\section{EXPERIMENTAL PROGRAM}

The experimental program was designed to proceed from relatively simple and inexpensive small-scale static and tilting-furnace capsule tests to tests in recirculating thermal and forced convection loops which more closely approximate the conditions of flow and temperature distribution that might arise in a processing plant. Materials which showed promise in capsule-scale tests and were also practical from the point of view of availability, high temperature strength, ease of fabrication, or compatibility with fuel were tested in recirculating loops.

A list of the materials tested is given in Table 1. Mill test reports for the tests involving the ternary eutectic are given in Appendix A. The metallic materials tested included mild steel, ferritic and austenitic stainless steels, high-nickel alloys, Ta, and Mo. This wide range was selected because of the general lack of corrosion information on which to base a narrower one. Mo, Ta, and the ceramic materials were of special interest as potential container materials for $\mathrm{BiCl}_{3}$ solutions.

The following corrodents were used: the $\mathrm{NaCl}$ $\mathrm{KCl}-\mathrm{MgCl}_{2}$ eutectic, the same with $5 \% \mathrm{BiCl}_{3}$ added, and each of these in the presence of the liquid metal fuel. Pure $\mathrm{BiCl}_{3}$ was used in one test, and $\mathrm{LiCl}-\mathrm{KCl}$ eutectic was used by itself in an early series of tests. Generally, the fuel and eutectic salt differed from what might be found in a processing plant principally in the absence of radiation and fission products. The effect of gamma radiation was determined in one experiment, but the effect 
of fission products had not been examined before the corrosion study was terminated.

Before discussion of the tests, a description is given below of certain experimental procedures used in most of them.

\section{Preparation and Handling of Corrodents}

It was essential that all purification and handling of purified corrodents in the liquid state be performed in an inert atmosphere, since both the liquid metal fuel and the fused salts are subject to rapid attack by atmospheric moisture. Inert atmospheres were essential in the tests themselves for the same reason. In addition, corrosion by fused salts is greatly enhanced by the presence of oxidizing impurities. Consequently, all apparatus for corrodent preparation or testing was thoroughly cleaned and tested for leak tightness (e.g., with a He mass spectrometer detector) before use. The inert atmospheres used were either $\mathrm{He}$ or $\mathrm{Ar}$, purified by passage over $\mathrm{Ti}$ chips at $850^{\circ} \mathrm{C}$.

Fuel that had been exposed to air in the solid state was slowly heated and melted under vacuum before use. Handling of purified solid salts was done in a dry box insofar as possible. Periods of handling in air outside a dry box were no longer than a few seconds and were immediately followed by evacuation and purging with $\mathrm{He}$.

The eutectic salts were prepared by vacuummelting the constituent salts in the proper proportions and outgassing at $500^{\circ} \mathrm{C}$ to a pressure of $<20 \mu \mathrm{Hg}$. Reagent grade Baker LiCl, $\mathrm{NaCl}$, and $\mathrm{KCl}$, General Chemical $\mathrm{BiCl}_{3}$, and Carborundum Metals Co. anhydrous $\mathrm{MgCl}_{2}$ were used. Small

Table 1

Materials Tested

\begin{tabular}{|c|c|c|}
\hline \multicolumn{3}{|c|}{ Metals and Alloys } \\
\hline 1020 Mild steel & 347 S.S. & Inor-8 \\
\hline $11 / 4 \mathrm{Cr}-1 / 2 \mathrm{Mo}$ steel & 410 S.S. & Hastelloy C \\
\hline 21/4 Cr - 1 Mo steel & 430 S.S. & Tantalum \\
\hline $5 \mathrm{Cr}$ steel & 16-1 Groloy & Molybdenum \\
\hline 304 (ELC) S.S. & 446 S.S. & Gold \\
\hline 310 S.S. & Inconel & Stellite 90 \\
\hline
\end{tabular}

\section{Ceramics}

$\mathrm{Al}_{2} \mathrm{O}_{3}$ (Norton Co. Mix A-402)

$\mathrm{MgO}$ (Norton Co. Mix M-202)

$\mathrm{ZrO}_{2}$ (Norton Co. Mix Z-301)

$\mathrm{SiC}$ (nitride bonded) batches of salt for the static tests were prepared in Pyrex, and 100-ib batches for the other experiments in 347 stainless steel tanks. In the latter case, the binary and ternary salts were contacted with $\mathrm{Bi}$ containing $0.5 \% \mathrm{Mg}, 0.5 \% \mathrm{U}$, and $0.025 \% \mathrm{Zr}$ before use in order to reduce any oxides present into the $\mathrm{Bi}$ phase. The $\mathrm{BiCl}_{3}$ was purified by vacuum sublimation at $225^{\circ} \mathrm{C}$. Prior to use, the salts were filtered through fine Pyrex or stainless steel frits.

The $\mathrm{Bi}, 99.999 \%$ pure, was degreased with acetone and dried. Spectrographically pure Johnson, Matthey $\mathrm{Mg}$ and reactor grade Zr from Zirconium Metals Co. were degreased with acetone, and natural $U$ was cleaned with nitric acid to remove surface oxides and also degreased with acetone. The Bi fuel, containing 1000 ppm U, 350 ppm $\mathrm{Mg}$, and $350 \mathrm{ppm} \mathrm{Zr}$, was prepared by dissolving weighed quantities of these additives in the $\mathrm{Bi}$ at $500^{\circ} \mathrm{C}$ with light vibration of the container.

\section{Test Specimen Preparation}

Flat metal tab specimens were used in the static and tilting-furnace experiments. One face was mechanically polished and the other electropolished or sandblasted to simulate possible surface cleaning treatments. Each specimen was weighed before testing. The loop test specimens were polished lengths of pipe welded directly into the flow circuit. A short section of each such specimen was set aside for reference. Specimens for the tiltingfurnace and loop tests were prepared from the same stock as that used in fabrication of the container. Ceramic tabs were dried to constant weight at $200^{\circ} \mathrm{C}$ before use.

\section{Specimen Examination and Corrodent Analysis}

On completion of the tests, each tilting-furnace capsule and thermal convection loop was radiographed to determine the location and extent of gross corrosion and deposition. Then, for all tests, test specimens were recovered and washed with distilled water to remove all traces of adhering salt. Ceramic specimens were refluxed with distilled water and dried to constant weight at $200^{\circ} \mathrm{C}$. Adhering $\mathrm{Bi}$ was removed from tab surfaces by dissolution in $\mathrm{Hg}$ at $200^{\circ} \mathrm{C}$. All capsule specimens were then weighed. Metallic specimens were examined metallographically to determine the type and extent of corrosion. Maximum depth of specimen penetration was measured on photomicrographs. Ceramic specimens were examined 
visually. Whenever possible, the corrodent solution and any plug material were analyzed chemically (Appendix B).

Capsule-scale experiments involved two to four replicate capsules for a given material. Although there was considerable scatter within groups of measured weight changes and depths of penetration for a given material, cases of substantial corrosion were clearly evident.

In the following sections, the tests are described and the results given in order of increasing size of the test apparatus used.

\section{STATIC TESTS}

Fifteen-gram batches of salt were weighed out in a dry box and placed in Pyrex capsules with $3 / 8 \times 3 / 8 \times 0.030$-in. test specimens. The capsules were sealed under vacuum and placed in a furnace maintained at $500^{\circ} \mathrm{C}$. The tests were performed in quadruplicate for $1000 \mathrm{hr}$.

\section{$\mathrm{LiCl}-\mathrm{KCl}$ Eutectic}

The results are shown in Table 2. Types 347 and 410 stainless steel offered the best corrosion resistance to the salt. $\mathrm{Cr}-5 \mathrm{Si}$ steel, $\mathrm{W}$, and Mo suffered such slight attack that it could not be measured at a magnification of $250 \times$. The $2 \frac{1}{4}$ $\mathrm{Cr}-1$ Mo steel showed intergranular attack of 0.3 mil; 5 Cr steel suffered from local transgranular

Table 2

Results of Static Screening Tests

Test duration: $\quad 1000 \mathrm{hr}$

Test temperature: $500^{\circ} \mathrm{C}$

Corrodent: $\quad \mathrm{LiCl}-\mathrm{KCl}$ eutectic

\begin{tabular}{llc}
\hline \multicolumn{1}{c}{ Material } & Type of corrosion & $\begin{array}{c}\text { Max. } \\
\text { penetration, } \\
\text { mils/yr }\end{array}$ \\
\hline 21/4 Cr -1 Mo steel $^{\text {I } \mathrm{Cr} \text { steel }}$ & $\begin{array}{l}\text { Intergranular } \\
\text { Local intergranular } \\
\text { and transgranular }\end{array}$ & 2.6 \\
$\mathrm{Cr}-5 \mathrm{Si}$ steel & Intergranular & 4.4 \\
347 S.S. & None & $<0.44$ \\
410 S.S. & None & 0 \\
Tungsten & Intergranular & $<0.44$ \\
Molybdenum & Intergranular & $<0.44$ \\
Tantalum & Pitting & 7.9 \\
\hline
\end{tabular}

*Average of 2 tests. and intergranular attack of $0.5 \mathrm{mil}$; and Ta pitted to a maximum depth of $0.9 \mathrm{mil}$.

In addition to undergoing the capsule test, type 410 stainless steel was also statically exposed to the binary salt in the surge tank of a thermal convection loop (L-2) in which U-Bi solution was circulated. ${ }^{7}$ No corrosion was observed after $3810 \mathrm{hr}$ of exposure at $550^{\circ} \mathrm{C}$

\section{$\mathrm{NaCl}-\mathrm{KCl}-\mathrm{MgCl}_{2}$ Eutectic}

Twelve metallic and four ceramic materials were exposed to the eutectic and to a solution of $5 \%$ $\mathrm{BiCl}_{3}$ in the eutectic in static corrosion tests.

The results are presented in Tables 3 and 4 . 5 Cr steel pitted, and Ta suffered embrittlement. None of the other metals was seriously attacked by the eutectic. On the other hand, with the $\mathrm{BiCl}_{3}$ solution, all the metallic specimens were severely corroded intergranularly and in some cases transgranularly as well (Figure 2). The 21/4 Cr - 1 Mo steel was pitted. All cases of attack were accompanied by significant weight losses and almost complete reduction of the $\mathrm{BiCl}_{3}$. The original surfaces of the metallic specimens were completely dissolved.

$\mathrm{Al}_{2} \mathrm{O}_{3}$ was the only ceramic tested which was not attacked by either the eutectic or a solution of $\mathrm{BiCl}_{3}$ in the eutectic. In both cases, $\mathrm{MgO}$ and $\mathrm{ZrO}_{2}$ cracked and spalled to some extent, while the nitride-bonded SiC crumbled completely. Although there was some loss of $\mathrm{BiCl}_{3}$, particularly with $\mathrm{MgO}$, no metallic $\mathrm{Bi}$ was found.

\section{$\mathrm{BiCl}_{3}$}

Several 1000-hr static tests were performed in $\mathrm{Py}$ rex capsules at $300^{\circ} \mathrm{C}$ to determine the resistance of Mo to a solution of pure $\mathrm{BiCl}_{3}$. No attack or weight change was observed on any of the specimens.

\section{Effect of Radiation}

One experiment was performed to determine the effect of gamma radiation on ternary salt corrosion. An evacuated, glass-lined, stainless steel capsule (Figure 3) was filled with ternary eutectic, and three polished and weighed type 347 stainless steel test tabs were immersed in it. Temperature was measured with a thermocouple inserted in a stainless steel thermowell. The thermowell was covered with a glass liner with attached hooks on which the test tabs were hung. The capsule was filled with salt charged directly from the purification 
Table 3

Results of Static Screening Tests* of Metals and Alloys

Test duration: $\quad 1000 \mathrm{hr}$

Test temperature: $500^{\circ} \mathrm{C}$

Corrodent

\begin{tabular}{|c|c|c|c|c|c|c|}
\hline \multirow[b]{2}{*}{ Material } & \multicolumn{3}{|c|}{$\mathrm{NaCl}-\mathrm{KCl}-\mathrm{MgCl}_{2}$ eutectic } & \multicolumn{3}{|c|}{$\mathrm{NaCl}-\mathrm{KCl}-\mathrm{MgCl}_{2}$ eutectic plus $5 \% \mathrm{BiCl}_{3}$} \\
\hline & Type of corrosion & $\begin{array}{c}\text { Max. } \\
\text { penetration, } \\
\text { mils/yr }\end{array}$ & $\begin{array}{c}\text { Approx. } \\
\text { weight } \\
\text { change, } \%\end{array}$ & Type of corrosion & $\begin{array}{l}\text { Approx. } \\
\text { weight } \\
\text { change, } \%\end{array}$ & $\begin{array}{l}\text { Residual } \\
\% \mathrm{BiCl}_{3} \\
\text { in salt }\end{array}$ \\
\hline 1020 Mild steel & None & 0 & -0.4 & Intergranular & -8 & 0.61 \\
\hline $1 \frac{1 / 4}{C r}-1 / 2$ Mo steel & & $\dagger$ & & Intergranular & -20 & 0.30 \\
\hline 5 Cr steel & Pitting & 17.5 & $\ddagger$ & & $\dagger$ & \\
\hline 21/4 Cr - 1 Mo steel & Intergranular & $<1$ & -2.6 & Pitting & -14 & 0 \\
\hline 347 S.S. & Intergranular & 1 & -0.6 & Intergranular & -30 & 0 \\
\hline 430 S.S. & & $\dagger$ & & " & -21 & 0.33 \\
\hline 16-1 Croloy & & $\dagger$ & & " & -22 & 0.30 \\
\hline 446 S.S. & Intergranular & $<1$ & -4.2 & " & -27 & 0 \\
\hline Inor-8 & & $\dagger$ & & $"$ & -20 & 0.25 \\
\hline Stellite-90 & $\begin{array}{l}\text { Intergranular } \\
\text { and transgranular }\end{array}$ & $<1$ & -0.2 & $\begin{array}{l}\text { Intergranular } \\
\text { and transgranular }\end{array}$ & -17.5 & 0 \\
\hline Molybdenum & None & 0 & 0 & & $\dagger$ & \\
\hline Tantalum & None** & 0 & 0 & & $\dagger$ & \\
\hline
\end{tabular}

* Results are averages of 2 to 4 tests.

**Tab showed embrittlement.

$\dagger$ Not tested.

$\ddagger$ Not measured.

Table 4

Results of Static Screening Tests* of Ceramics

Test duration: $\quad 1000 \mathrm{hr}$

Test temperature: $\quad 500^{\circ} \mathrm{C}$

\begin{tabular}{|c|c|c|c|c|c|}
\hline \multirow[b]{3}{*}{ Material } & \multicolumn{5}{|c|}{ Corrodent } \\
\hline & \multicolumn{2}{|c|}{$\mathrm{NaCl}-\mathrm{KCl}-\mathrm{MgCl}_{2}$ eutectic } & \multicolumn{3}{|c|}{$\mathrm{NaCl}-\mathrm{KCl}-\mathrm{MgCl}_{2}$ eutectic plus $5 \% \mathrm{BiCl}_{3}$} \\
\hline & $\begin{array}{c}\text { Condition of } \\
\text { specimen after test }\end{array}$ & $\begin{array}{c}\text { Approx. } \\
\text { weight } \\
\text { change, } \%\end{array}$ & $\begin{array}{c}\text { Condition of } \\
\text { specimen after test }\end{array}$ & $\begin{array}{c}\text { Approx. } \\
\text { weight } \\
\text { change, } \%\end{array}$ & $\begin{array}{c}\text { Residual } \\
\% \mathrm{BiCl}_{3} \\
\text { in salt }\end{array}$ \\
\hline $\mathrm{Al}_{2} \mathrm{O}_{3}$ (Norton Mix A-402) & $\begin{array}{l}\text { No spalling } \\
\text { or cracking }\end{array}$ & -0.14 & $\begin{array}{l}\text { No spalling } \\
\text { or cracking }\end{array}$ & +0.3 & 4.5 \\
\hline $\mathrm{MgO}$ (Norton Mix M-202) & $\begin{array}{l}\text { All specimens } \\
\text { cracked and spalled }\end{array}$ & +6 & $\begin{array}{l}\text { All specimens } \\
\text { cracked and spalled }\end{array}$ & +10 & 2.1 \\
\hline $\mathrm{ZrO}_{2}$ (Norton Mix Z-301) & Moderately spalled & -1.6 & Slight attack & +0.1 & 4.4 \\
\hline $\mathrm{SiC}$ (nitride bonded) & $\begin{array}{l}\text { All specimens } \\
\text { crumbled completely }\end{array}$ & - & $\begin{array}{l}\text { All specimens } \\
\text { crumbled completely }\end{array}$ & - & 3.5 \\
\hline
\end{tabular}

*Results are averages of 2 to 4 tests. 

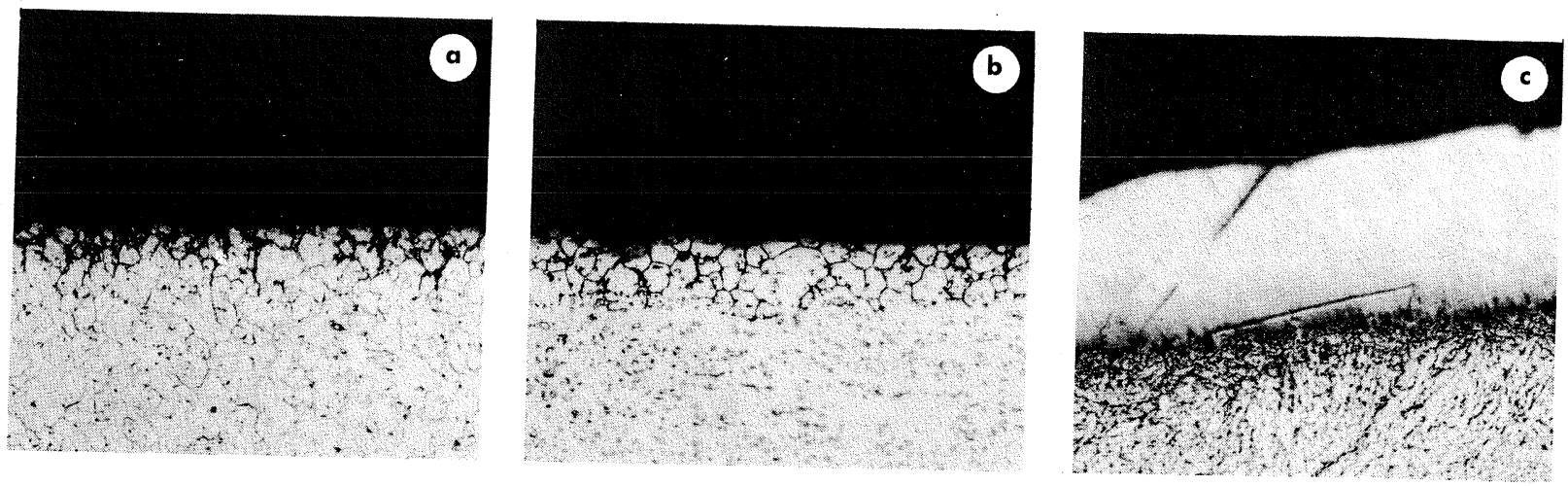

Figure 2. Photomicrographs $(250 \times)$ of specimens exposed to static $\mathrm{NaCl}-\mathrm{KCl}-\mathrm{MgCl}_{2}$ eutectic containing $5 \% \mathrm{BiCl}_{3}$ for $1000 \mathrm{hr}$ at $500^{\circ} \mathrm{C}$. Surfaces shown are polished sides of tabs. (a) Type 347 stainless steel; Marbles etch. (b) Type 446 stainless steel; HCl, picric acid, alcohol etch. (c) $2 \frac{1 / 4}{\mathrm{Cr}}-1$ Mo alloy steel showing Bi deposit; nital etch.

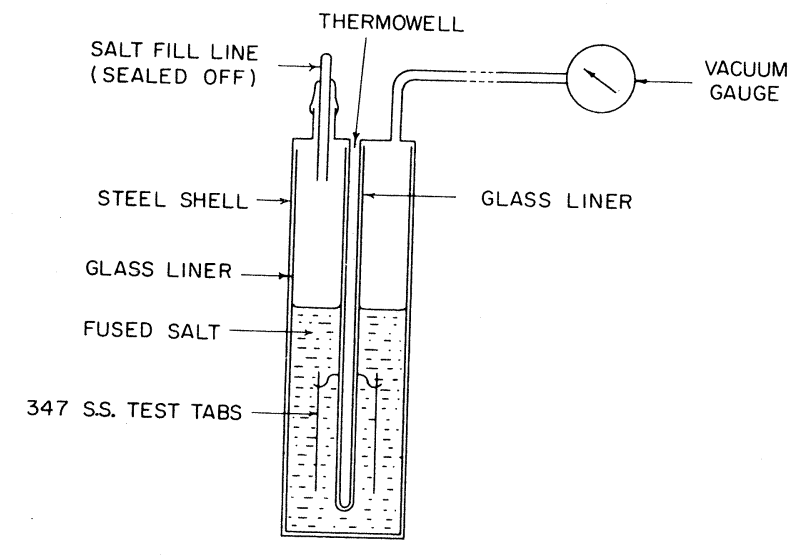

Figure 3. Schematic diagram of apparatus for salt corrosion test in a $\mathrm{Co}^{60}$ gamma radiation field.

apparatus through a glass fill connection which was then sealed. A Calrod heater was wrapped around the outside of the capsule, and the whole unit insulated. A vacuum gauge was connected to the capsule. The capsule was exposed to a $\mathrm{Co}^{60}$ gamma radiation field for $1050 \mathrm{hr}$ at $500^{\circ} \mathrm{C}$. The salt was exposed to an average intensity of 183,000 $\mathrm{r} / \mathrm{hr}$ and the steel tabs to $157,000 \mathrm{r} / \mathrm{hr}$.

The lack of any measurable gas build-up within the capsule during the test indicated the absence of substantial salt decomposition. No corrosion was observed on the steel tabs, which still retained their metallographic polish at the end of the run.

A very thin film of a nonmetallic nature was observed on the lower part of the tabs (Figure 4). An unsuccessful attempt was made to identify this

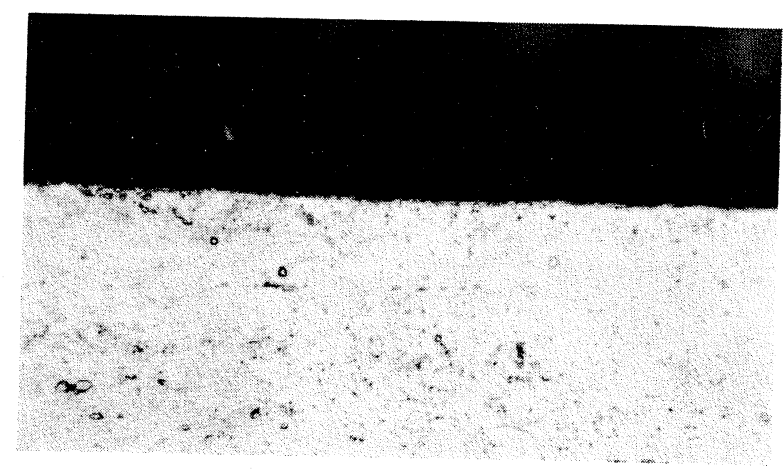

Figure 4. Photomicrograph $(500 \times)$ of type 347 stainless steel specimen exposed to $\mathrm{NaCl}-\mathrm{KCl}-\mathrm{MgCl}_{2}$ eutectic for $1050 \mathrm{hr}$ at $500^{\circ} \mathrm{C}$ in a $\mathrm{Co}^{60}$ gamma radiation field. Salt dose rate: 183,000 r/hr. Specimen dose rate: $157,000 \mathrm{r} / \mathrm{hr}$. Note deposit on polished surface. Marbles etch.

film by $\mathrm{x}$-ray analysis. It is believed to be an oxide, and probably came from the salt.

\section{TILTING-FURNACE CAPSULE TESTS}

The tilting-furnace is a relatively simple apparatus for initial screening tests of materials for resistance to corrosion in the presence of flow and temperature differences. Because of its simplicity and the fact that both one- and two-phase corrodents could be accommodated, it was widely used in the present investigation.

The apparatus consisted of six furnaces mounted on a motor-driven tilting angle-iron framework (Figure 5). The furnaces were made from 18-in.-long, 13/4-in.-i.d. Mullite tubes (Figure 6) 


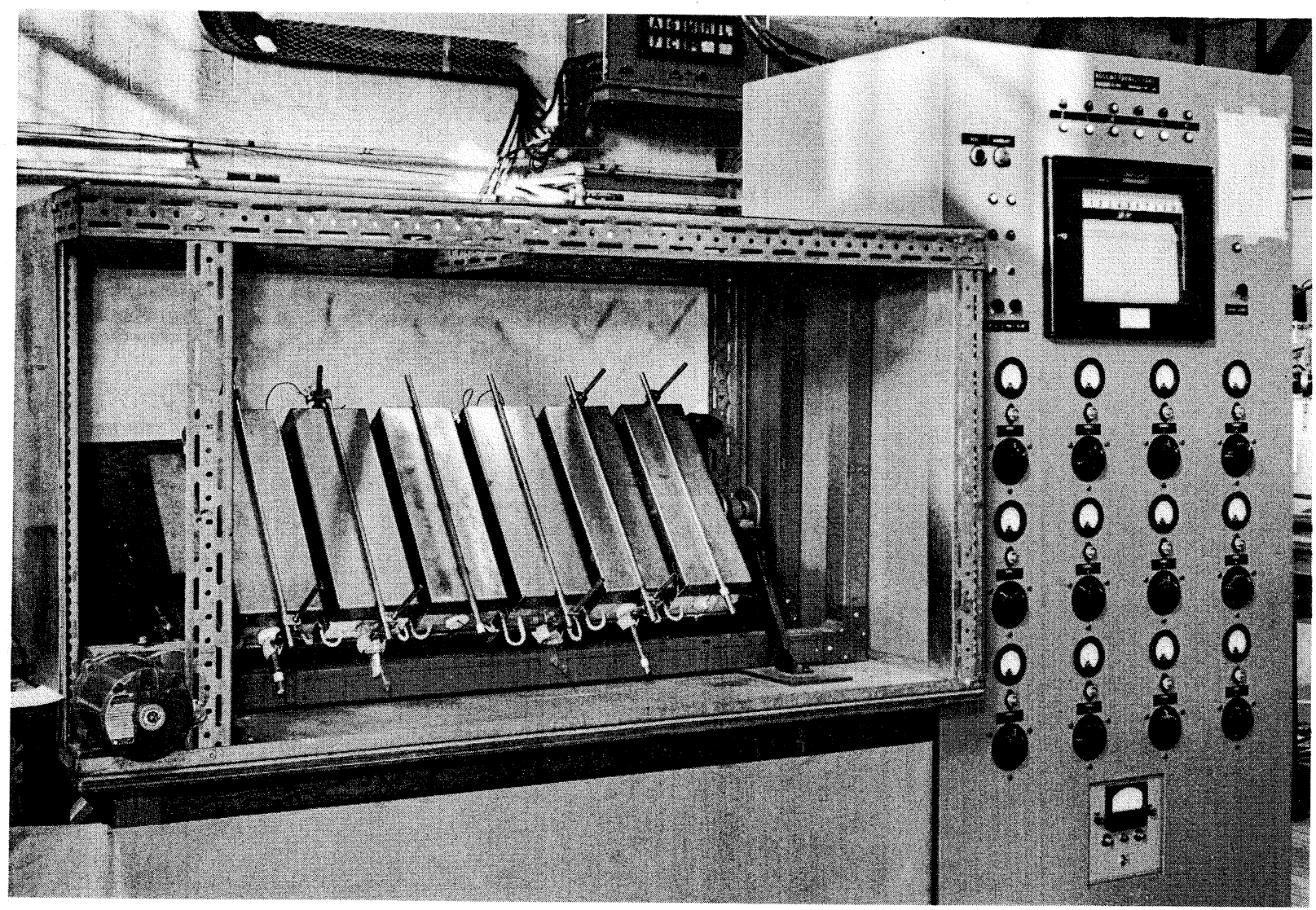

Figure 5. Tilting-furnace apparatus.

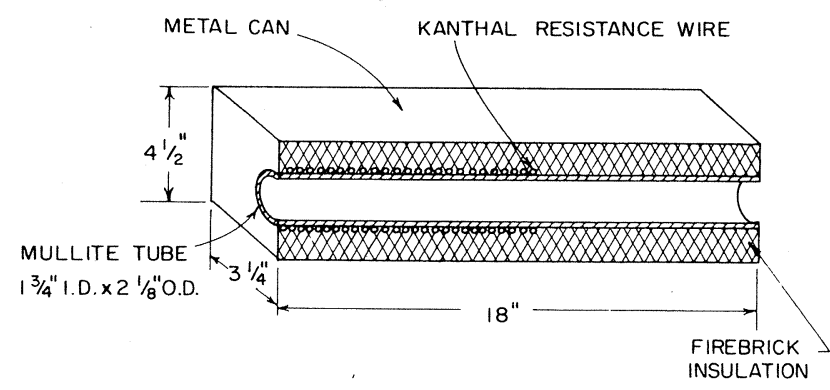

Figure 6. Schematic diagram of a tilting-furnace.

wound with Kanthal A resistance heater wire. One end of each tube was not wound with heater wire in order to promote an axial temperature gradient in capsules placed in the furnaces. Flow of corrodents within the capsules was obtained by slowly tilting the furnaces back and forth. The tilting cycle was $125 \mathrm{sec}$ with a 37 -sec delay at each extreme position to allow equilibration of the corrodent temperatures. To achieve this operation,

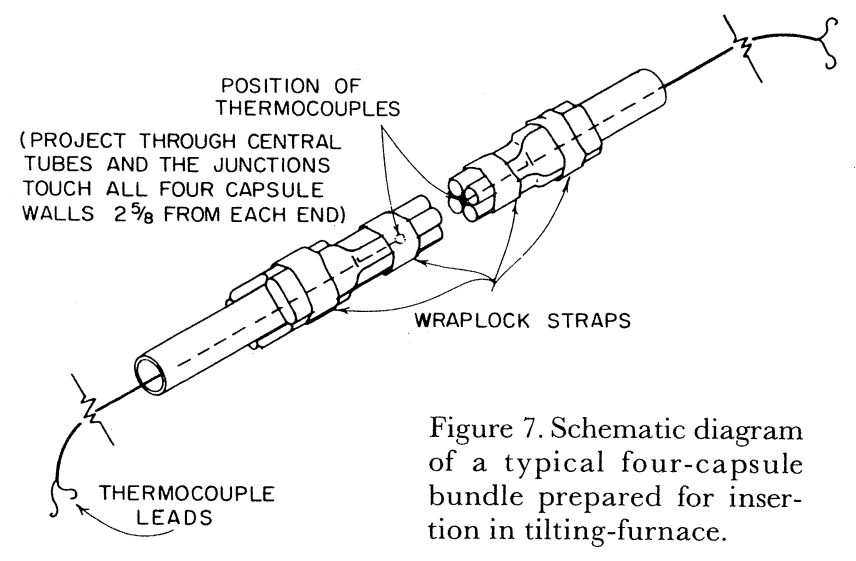

the driving motor was interrupted and restarted by an air-operated time-delay, which was in turn actuated by a cam and microswitch arrangement on the angle-iron framework. The axial position of the capsules within the furnaces was adjusted so that the cold ends were maintained at $450^{\circ} \mathrm{C}$ while the hot ends were controlled at $500^{\circ} \mathrm{C}$ by a thermocouple and temperature recorder controller. Tests were carried out in duplicate for 1000 
A. INITIAL LENGTH OF TUBE OR PIPE

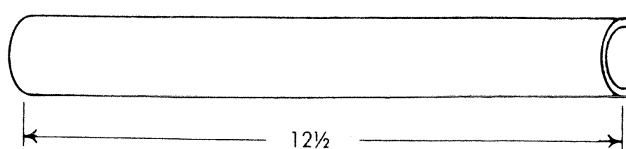

B. DETAIL OF CAPSULE HOT END CRIMPS

*PRESSURE VARIES WITH CAPSULE MATERIAL

C. DETAIL OF POLISHED TAB CRIMPS

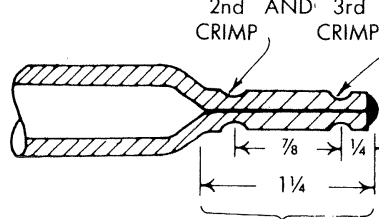

1st CRIMP POLISHED TAB

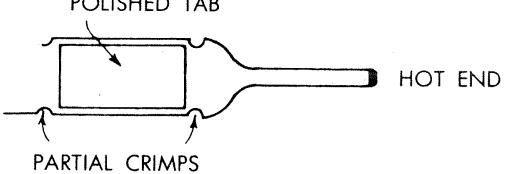

(USING SHARP TOOL 5000 - 12,000 LBS* WITH $1.544^{\prime \prime}$ DIA. RAM)

PARTIAL CRIMPS

D. TECHNIQUE FOR CRIMPING COLD END (AFTER FILLING CAPSULE WITH CORRODENT)

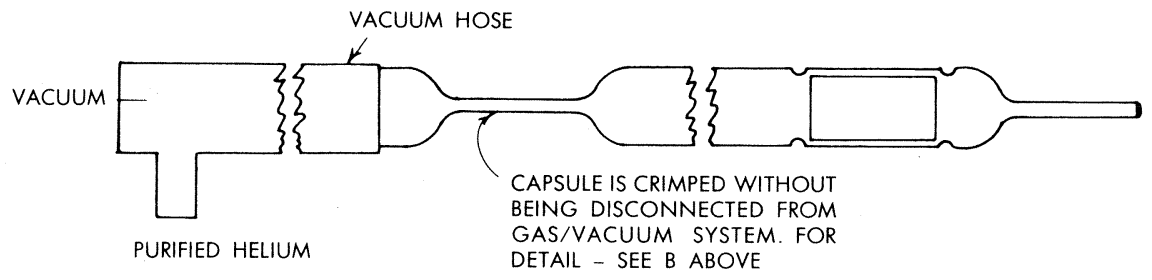

E. FINAL CAPSULE

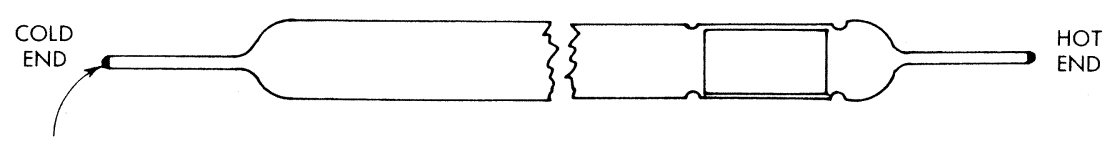

AFTER CUTTING CRIMP IS SEAL WELDED WHILE STILL HELD IN THE JAWS OF THE HYDRAULIC RAM

or $2500 \mathrm{hr}$ in capsules made from fully annealed tubing or pipe. Test tabs were formed from the same stock and mounted in the hot end of the capsules. A group of two or four capsules was bundled together with two thermocouples and tested in a single furnace. The two thermocouple measuring junctions were located on the axis of the capsule bundle in contact with each capsule, as shown in Figure 7. One thermocouple measured and controlled the temperature at the hotter ends of the capsules, and the other measured the temperature at the colder ends.

With the particular capsule and furnace design used, it was found that the maximum temperature existed near the middle of the capsule rather than at the hot end where the test tab was located (see Appendix C). Corrosion product content of corrodent and corrosion product deposition could
Figure 8. Steps in preparation of tilting-furnace capsule.

not, therefore, be principally associated with attack on test tabs. In spite of this limitation, the design was thought to be adequate for screening purposes.

A capsule was prepared as follows. A 12.5-in. length of pipe or tubing (Figure 8a) was sandblasted internally to remove any residual surface deposits. One end was then sealed by crimping in a hydraulic ram (Appendix D) followed by inertarc fusion welding (Figure 8b). A test tab was then inserted into the tube and properly positioned and restrained in the sealed tube end by partial crimping (Figure 8c). After the first crimp was leak tested with a $\mathrm{He}$ mass spectrometer, the capsule was outgassed in a quartz tube at $550^{\circ}$ to a pressure $<2 \mu \mathrm{Hg}$.

The capsule was then transferred to a glass filling apparatus (Figure 9). The purified ternary 


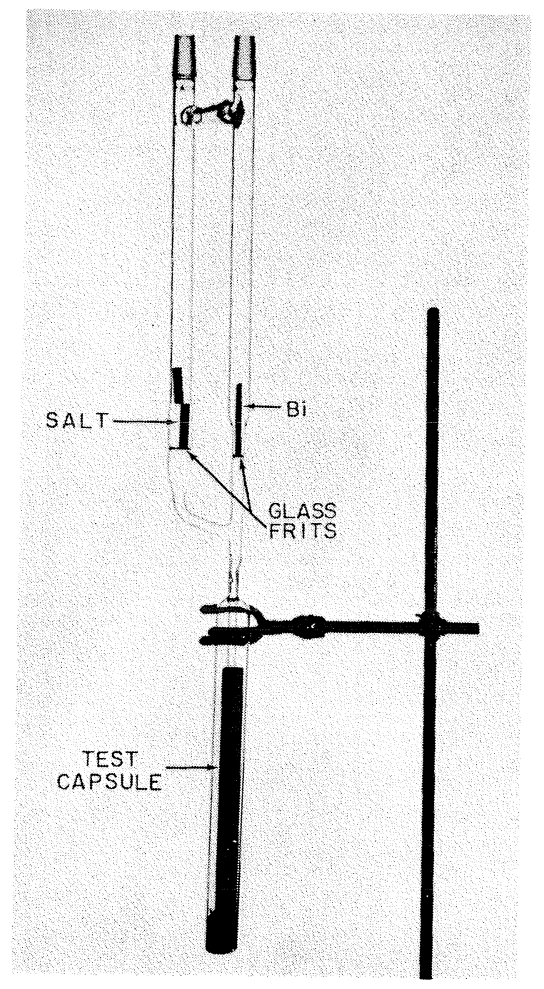

Figure 9. Apparatus in which tilting-furnace capsules were filled.

eutectic was charged into the left arm. For experiments involving both phases, Bi containing 1000 ppm U, $350 \mathrm{ppm} \mathrm{Mg}$, and $350 \mathrm{ppm} \mathrm{Zr}$ was prepared by charging weighed quantities of $\mathrm{Bi}, \mathrm{U}$, $\mathrm{Mg}$, and $\mathrm{Zr}$ into the right arm. In the single-phase experiments, just sufficient salt was used to immerse the test tab completely when it was in its lowest position in the tilting cycle. In the twophase experiments, the test tab was again just fully immersed in this position with the Bi-salt interface at its center. The corrodents were vacuum-melted, and the fuel additives were dissolved by lightly vibrating the glass apparatus for about $2 \mathrm{hr}$. The corrodents were then filtered through Pyrex frits into the capsules below by use of Ar pressure. While the capsule was still blanketed with Ar, the lower section of the glass apparatus containing the capsule was sealed off.

Then, after the capsule cooled to room temperature, it was removed from the glass envelope, and its open end was quickly connected to a vacuum and purified He system. After the capsule was purged several times, it was filled with $\mathrm{He}$ to a pressure of 3 psig, and the open end was crimped

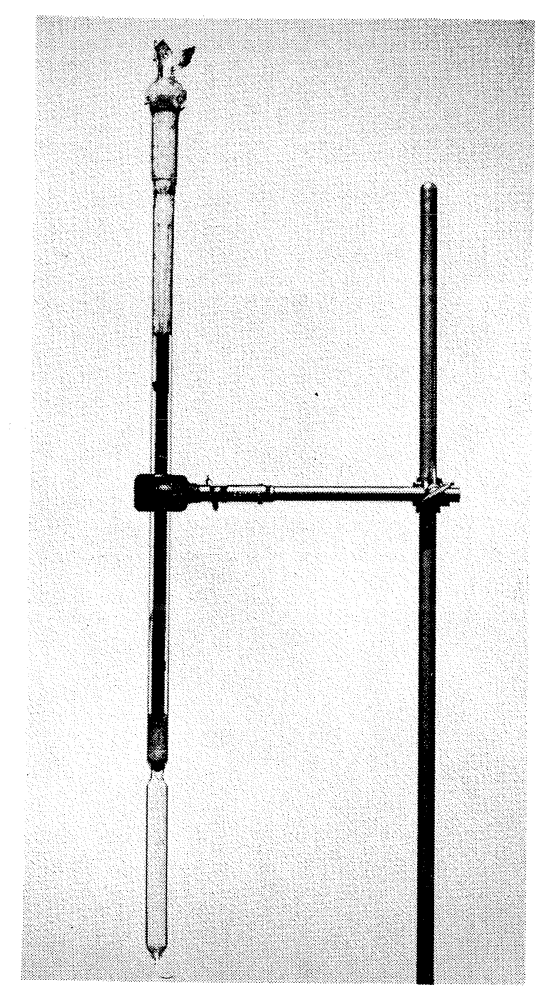

Figure 10. Glass-enclosed tilting-furnace capsule.

(Figure 8d). While the tube was still held in the jaws of the hydraulic ram, its end was cut and seal-welded (Figure 8e). The integrity of this last seal-weld was checked by placing the capsule in a glass tube at $500^{\circ} \mathrm{C}$ and evacuating it to a mass spectrometer leak detector.

Most capsules were prepared as described above, but in certain cases it was necessary to modify the procedure. Mo, which is very brittle, and 1020 mild steel capsules, which had thick walls, could not be crimped, and both Mo and Ta, which are susceptible to air oxidation at high temperatures, had to be tested in the absence of air. The Mo and 1020 mild steel closures were made by inserting plugs into the capsule ends and then sealwelding them. The hot ends of the 1020 mild steel capsules were sealed in the open by inert-arc welding. After the capsule was filled, the second tube end (and both Mo tube ends) was sealwelded in a dry box. The atmosphere of Ar in the dry box had a dew point of $-70^{\circ} \mathrm{C}$.

The sealed Ta and Mo capsules were then enclosed in glass capsules under Ar in order to protect them from external air oxidation. Figure 10 

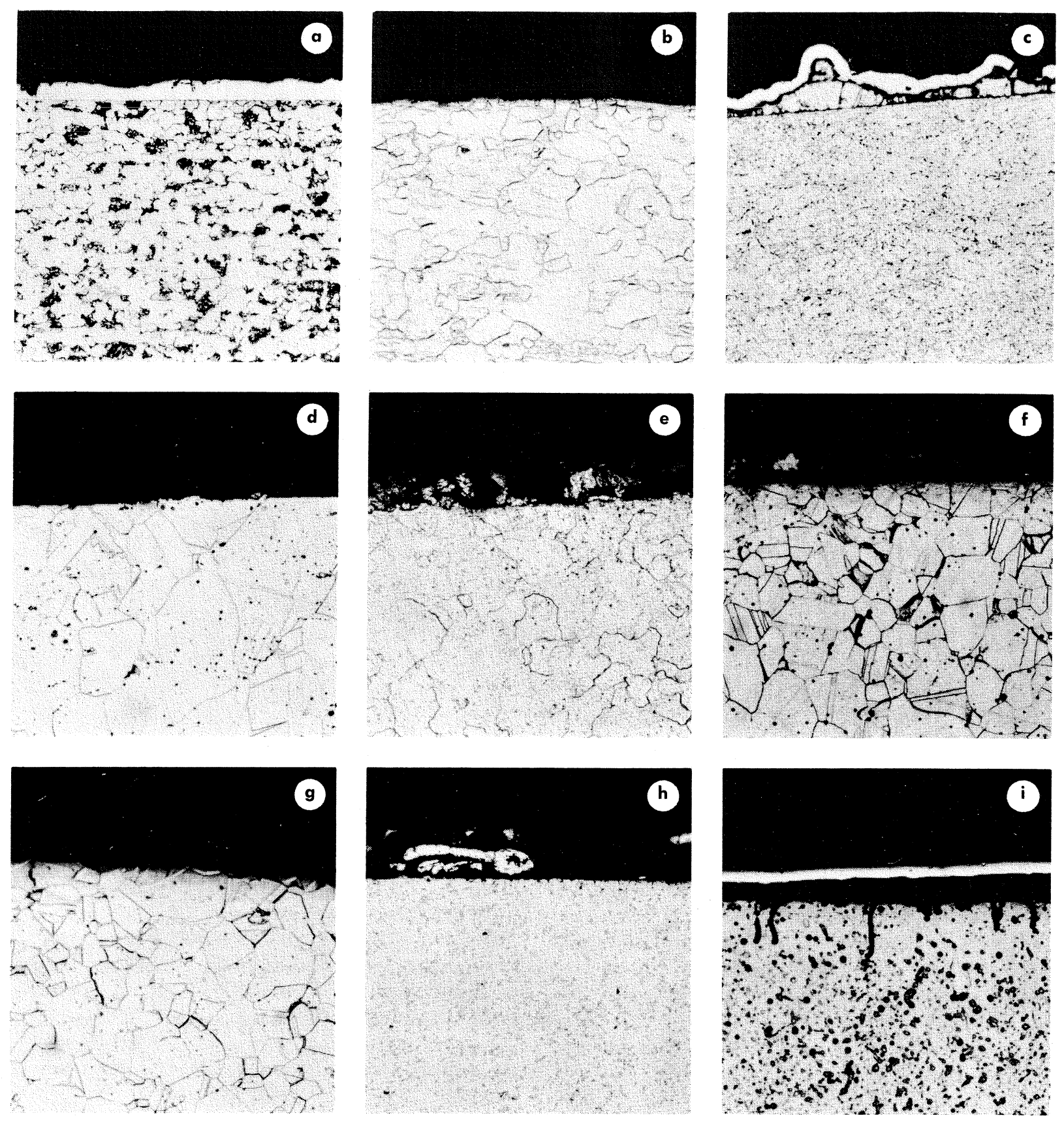

Figure 11. Photomicrographs $(250 \times)$ of specimens exposed to $\mathrm{NaCl}-\mathrm{KCl}-\mathrm{MgCl}_{2}$ in the tiltingfurnace apparatus for $1000 \mathrm{hr}$ (except as noted otherwise). Specimens were located in hot ends of capsules with hot end at $500^{\circ} \mathrm{C}$ and cold end at $450^{\circ} \mathrm{C}$. Capsule designation is given in parentheses. (a) 1020 mild steel (T-12). Section through polished surface; nital etch. (b) Mo (K-12). Section through polished surface; etch: $\mathrm{K}_{3} \mathrm{Fe}(\mathrm{CN})_{6}, \mathrm{KOH}$ in $\mathrm{H}_{2} \mathrm{O}$. (c) $2^{1 / 4} \mathrm{Cr}-1$ Mo alloy steel ( J-16). Section through cold end of polished side of specimen after 2500-hr exposure; nital etch. Note mass transfer deposit. (d) Inor-8 (P-13). Section through polished surface; aqua regia etch. (e) Type 410 stainless steel (E-13). Section through polished surface; etch: HCl, picric acid, alcohol. (f) Type 316 stainless steel (C-12). Section through polished surface; Marbles etch. (g) Inconel (G-13). Section through polished surface; etch: $\mathrm{HCl}, \mathrm{HNO}_{3}$. (h) Type 446 stainless steel (F-12). Section through polished surface; etch: HCl, picric acid, alcohol. (i) Ta (L-14). Section through polished surface; etch: $\mathrm{HF}, \mathrm{HNO}_{3}$. 
Table 5

Results of Tilting-Furnace Screening Tests* Without $\mathrm{BiCl}_{3}$

Test temperature difference: $50^{\circ} \mathrm{C}\left(500^{\circ}-450^{\circ}\right)$

Test duration:

$1000 \mathrm{hr}$ (except where noted)

\begin{tabular}{|c|c|c|c|c|c|c|}
\hline \multirow[b]{3}{*}{ Material } & \multicolumn{6}{|c|}{ Corrodent } \\
\hline & \multicolumn{3}{|c|}{$\mathrm{NaCl}-\mathrm{KCl}-\mathrm{MgCl}_{2}$ eutectic } & \multicolumn{3}{|c|}{$\mathrm{Bi}-\mathrm{U}$ fuel/ternary eutectic } \\
\hline & $\begin{array}{c}\text { Type of } \\
\text { corrosion on } \\
\text { polished side }\end{array}$ & $\begin{array}{l}\text { Maximum } \\
\text { penetration, } \\
\text { mils/yr }\end{array}$ & $\begin{array}{l}\text { Weight } \\
\text { change of tab, } \\
\mathrm{mg} / \mathrm{cm}^{2}-\mathrm{yr}\end{array}$ & $\begin{array}{c}\text { Type of } \\
\text { corrosion on } \\
\text { polished side }\end{array}$ & $\begin{array}{l}\text { Maximum } \\
\text { penetration, } \\
\text { mils/yr }\end{array}$ & $\begin{array}{c}\text { Weight } \\
\text { change of tab, } \\
\mathrm{mg} / \mathrm{cm}^{2}-\mathrm{yr}\end{array}$ \\
\hline 1020 Mild steel & None & 0 & -22 & None & 0 & +3.3 \\
\hline $2^{1 / 4} \mathrm{Cr}-1$ Mo steel & $\begin{array}{l}\text { Intergranular and } \\
\text { transgranular }\end{array}$ & $d$ & +12.2 & None & 0 & +3.8 \\
\hline $21 / 4 \mathrm{Cr}-1$ Mo steel $* *$ & None & 0 & 32 & None & 0 & +0.6 \\
\hline 304 (ELG) S.S. & Intergranular & $<0.4$ & -12.1 & $\begin{array}{l}\text { Intergranular and } \\
\text { transgranular }\end{array}$ & 15 & -9.8 \\
\hline 310 S.S. & None & 0 & -2.8 & $\begin{array}{l}\text { Intergranular and } \\
\text { transgranular }\end{array}$ & 6.4 & -102 \\
\hline $\begin{array}{l}316 \text { S.S. } \\
347 \text { S.S. }\end{array}$ & $\begin{array}{l}\text { Intergranular } \\
\text { Intergranular and }\end{array}$ & $<0.4$ & -2.9 & Intergranular & 6.0 & -7.1 \\
\hline & transgranular & 4.7 & -4.6 & " & 10 & -7.2 \\
\hline 410 S.S. & Intergranular & 1.0 & -4.1 & " & 6 & -57 \\
\hline 430 S.S. & Transgranular & 2 & -0.8 & $"$ & 5.2 & Not measured \\
\hline 16-1 Croloy & Intergranular & $<0.4$ & +10.7 & $" 1$ & 4.4 & -40 \\
\hline 446 S.S. & Intergranular & $<0.4$ & +4.2 & None & 0 & -3 \\
\hline Inconel & Intergranular & 1.8 & -3.2 & $\begin{array}{l}\text { Intergranular and } \\
\text { transgranular }\end{array}$ & $\begin{array}{l}\text { Too extensive } \\
\text { to measure }\end{array}$ & -525 \\
\hline Hastelloy $\mathrm{C}$ & Not tested & & & $\begin{array}{l}\text { Intergranular and } \\
\text { transgranular }\end{array}$ & 32 & -162 \\
\hline Inor-8 & Transgranular & 2 & Not measured & $\begin{array}{l}\text { Intergranular and } \\
\text { transgranular }\end{array}$ & $\begin{array}{l}\text { Too extensive } \\
\text { to measure }\end{array}$ & -1000 \\
\hline Molybdenum & None & 0 & -2.8 & None & 0 & +0.4 \\
\hline Tantalum & Intergranular & 2.9 & -1.0 & Transgranular & 4.1 & -8.3 \\
\hline
\end{tabular}

* Results are averages of 2 tests.

$* *$ Test duration $=2500 \mathrm{hr}$.

Table 6

Results of Tilting-Furnace Screening Tests* (Welded Tabs)

Test temperature differences: $50^{\circ} \mathrm{C}\left(500^{\circ}-450^{\circ}\right)$

Test duration: $\quad 2500 \mathrm{hr}$

Corrodent: $\quad \mathrm{NaCl}-\mathrm{KCl}-\mathrm{MgCl}_{2}$ eutectic

\begin{tabular}{|c|c|c|c|c|c|}
\hline \multirow[b]{2}{*}{ Material } & \multicolumn{2}{|c|}{ Polished side of tab } & \multirow[b]{2}{*}{$\begin{array}{l}\text { Weight } \\
\text { change of } \mathrm{tab} \\
\mathrm{mg} / \mathrm{cm}^{2}-\mathrm{yr}\end{array}$} & \multicolumn{2}{|l|}{ Weld } \\
\hline & $\begin{array}{l}\text { Type of } \\
\text { corrosion }\end{array}$ & $\begin{array}{c}\text { Max. } \\
\text { penetration, } \\
\text { mils/yr }\end{array}$ & & Type of corrosion & $\begin{array}{c}\text { Max. } \\
\text { penetration, } \\
\text { mils/yr }\end{array}$ \\
\hline $2^{1 / 4} \mathrm{Cr}-1$ Mo steel & Transgranular & $<0.15$ & +34.0 & Intergranular and transgranular & $<0.15$ \\
\hline 347 S.S. & $" 1$ & 0.7 & -1.2 & Transgranular & 0.2 \\
\hline 446 S.S. & $"$ & 0.25 & -14 & Intergranular and transgranular & $<0.15$ \\
\hline Inconel & $"$ & 0.5 & +0.16 & Transgranular & 0.7 \\
\hline
\end{tabular}

*Results are averages of 2 tests. Welds were stress relieved. 

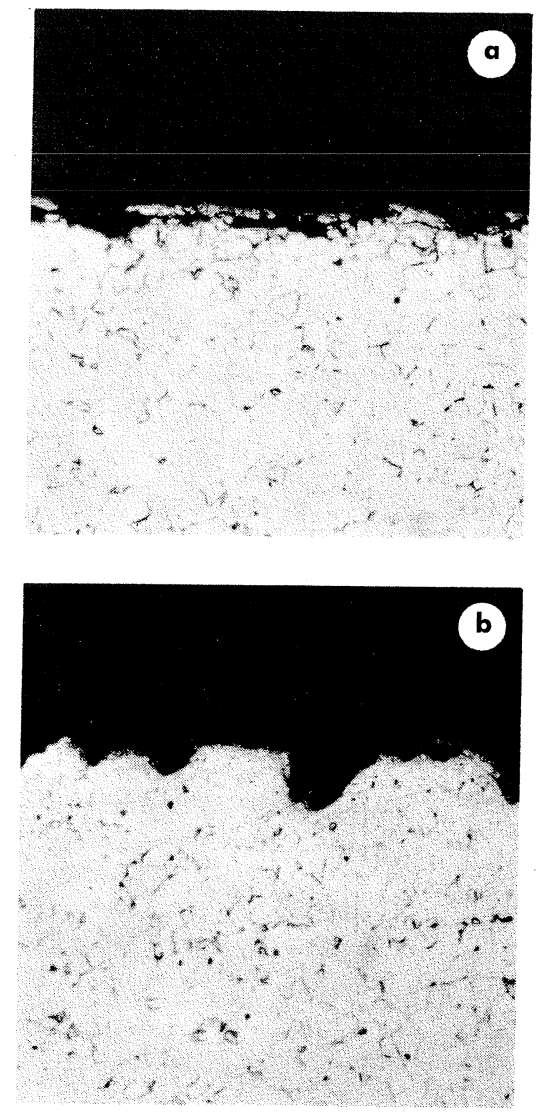

Figure 12. Photomicrographs $(250 \times)$ of specimen of type 347 stainless steel (capsule D-12) exposed to NaCl-KGl$\mathrm{MgCl}_{2}$ eutectic for $1000 \mathrm{hr}$ in the tilting-furnace apparatus. Specimen located in hot end of capsule with hot end at $500^{\circ} \mathrm{C}$ and cold end at $450^{\circ} \mathrm{C}$. Marbles etch. (a) Section through polished surface. (b) Section through sandblasted surface.

shows a typical glass-enclosed Mo capsule. Four glass-to-metal seals for thermocouple leads are located at the upper end of the glass envelope.

The procedure followed for preparing those metallic capsules which contained $\mathrm{BiCl}_{3}$ was identical to that described above except that in all cases both the $\mathrm{BiCl}_{3}$ additions and the final closures were made in the dry box.

The filling procedure for the glass capsules containing long Au tabs running their entire length was considerably simplified. The purified salt was charged into the glass filling apparatus, vacuummelted, and filtered with He pressure into the glass test capsule containing the test tab and $\mathrm{BiCl}_{3}$. While still under the $\mathrm{He}$ blanket, the glass capsule was sealed off. In these runs, the $\mathrm{BiCl}_{3}$ was not added in a dry box, but the weighings and ad-
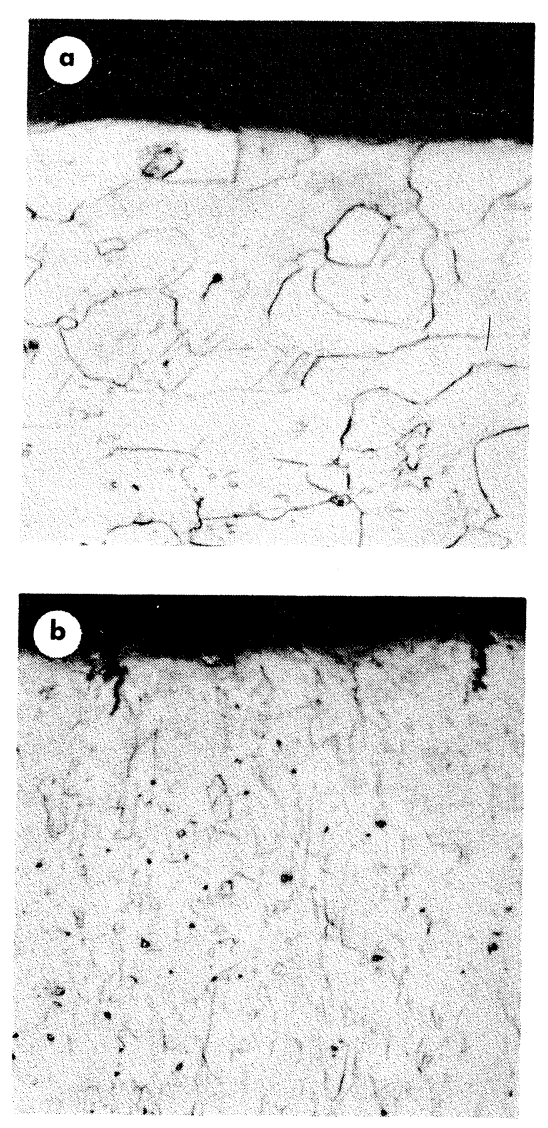

Figure 13. Photomicrographs $(250 \times)$ of Ta (capsule L19) exposed to $\mathrm{NaCl}-\mathrm{KCl}-\mathrm{MgCl}_{2}$ eutectic for $1000 \mathrm{hr}$ in the tilting-furnace apparatus. Polished specimen located in hot end of apparatus with hot end at $500^{\circ} \mathrm{C}$ and cold end at $450^{\circ} \mathrm{C}$. Etch: $\mathrm{HF}, \mathrm{NH}_{4} \mathrm{~F}$. (a) Section through polished specimen surface. (b) Section through inner surface of capsule wall.

ditions were done as rapidly as possible to minimize exposure to air.

All corrodent combinations except LiCl-KCl eutectic were used in the tilting-furnace tests. Typical photomicrographs showing a specimen from each group of similar materials (e.g., 300 series stainless steels, 400 series stainless steels, etc.) are shown in Figures 11 to 18. Data for individual capsules including corrodent chemical analyses are given in Appendix E. The results follow.

\section{$\mathrm{NaCl}-\mathrm{KCl}-\mathrm{MgCl}_{2}$ Eutectic Tests}

Type 310 stainless steel, 1020 mild steel (Figure 11a), and Mo (Figure 11b) were not attacked after 1000-hr exposure to eutectic salt (Table 5). No corrosion was found in a 2500 -hr test of $2 \frac{1 / 4}{4}$ $\mathrm{Cr}-1 \mathrm{Mo}$ steel (Figure 11c). Slight intergranular 

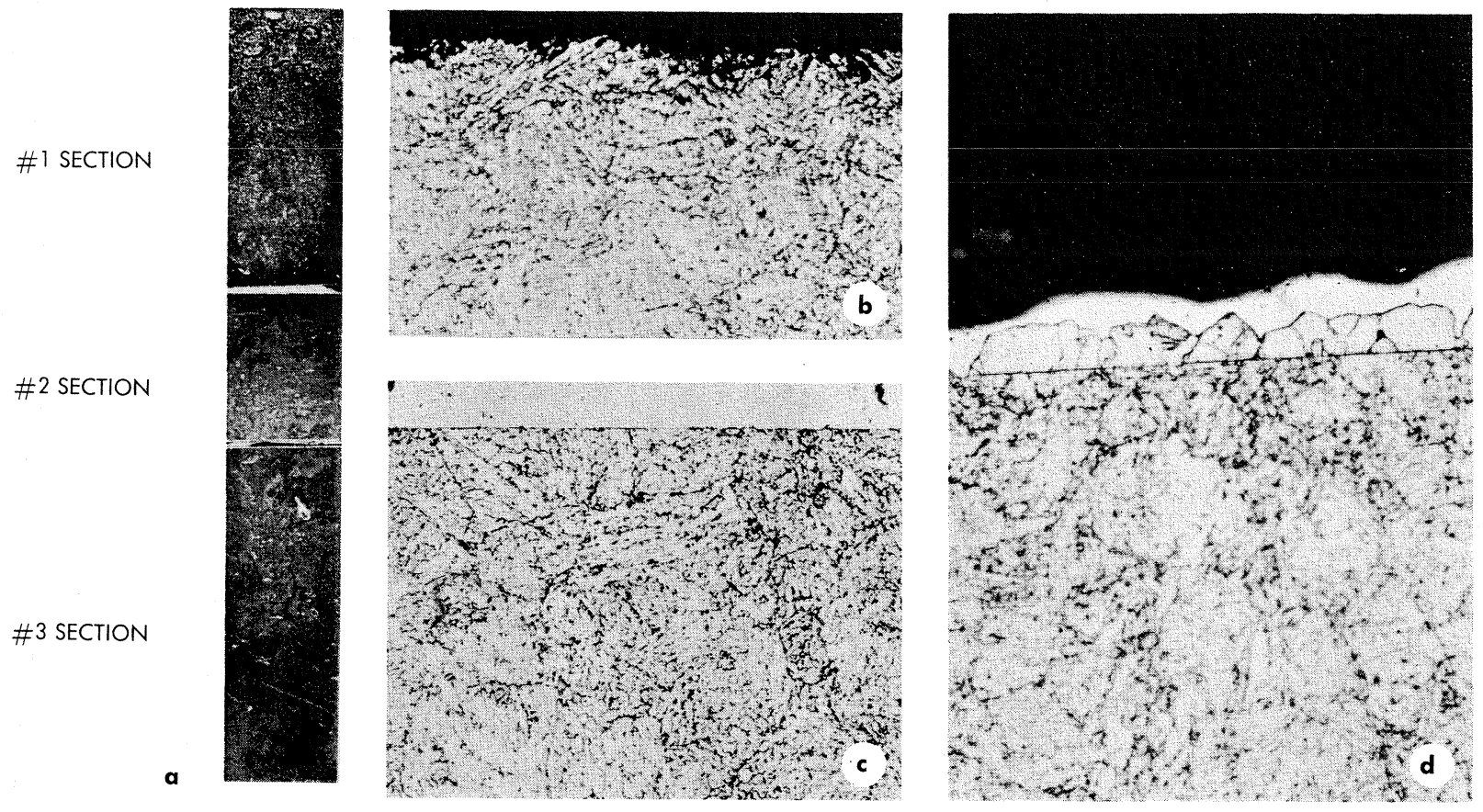

Figure 14. 21/4 $\mathrm{Cr}-1$ Mo alloy steel specimen (capsule J-12) exposed to NaCl- $\mathrm{KCl}-\mathrm{MgCl}_{2}$ eutectic for $1000 \mathrm{hr}$ in the tilting-furnace apparatus. Specimen located in hot end of capsule with hot end at $500^{\circ} \mathrm{C}$ and cold end at $450^{\circ} \mathrm{C}$. Nital etch. (a) Photograph of assembled specimen. Photomicrographs $(250 \times)$ : (b) Section through polished surface at hot end (\#3 section). (c) Section through polished surface of central portion (\#2 section). (d) Section through polished surface of cold end (\#1 section).

corrosion of most of the other materials was found. Type 347 stainless steel (Figure 12a) and 21/4 Cr 1 Mo steel (1000-hr test) were attacked transgranularly also. Inor-8 (Figure 11d) and type 430 stainless steel showed slight transgranular attack only. Traces of magnetic deposition were present in the cold ends of several capsules, but in amounts too small for analysis.

Figures $12 \mathrm{a}$ and $12 \mathrm{~b}$ illustrate the difference in the attack found on sandblasted and mechanically polished surfaces of a single tab. Figures 13a and $13 \mathrm{~b}$ illustrate the results obtained in two of the 1000-hr exposures of Ta to the ternary salt, when no attack was found on the test tab, but intergranular corrosion was found on the capsule wall. Evidence for mass transfer from one end of a test tab to the other was found in one $21 / 4 \mathrm{Cr}-1 \mathrm{Mo}, 1000$ hr test (Figure 14). A photograph of the assembled tab is shown in Figure 14a. Attack is indicated at the hotter end (Figure 14b); no attack is seen in the central portion (Figure 14c); and deposition of material (which was magnetic) is found at the colder end (Figure 14d).
Similar results (Table 6 ) were obtained when stress-relieved weld specimens of $2^{1 / 4} \mathrm{Cr}-1 \mathrm{Mo}$ steel, types 347 and 446 stainless steel, and Inconel were tested for $2500 \mathrm{hr}$ (Figure 15). Negligible corrosion was observed at each weld.

Chemical analyses (see Appendix E) of the corrodents from the steel and $\mathrm{Ni}$ alloy capsules showed that $\mathrm{Cr}$ was present in the largest concentration ( 75 to $>1000 \mathrm{ppm}$ ), followed by Fe (20 to $190 \mathrm{ppm}$ ) and $\mathrm{Mn}$ (20 to $320 \mathrm{ppm}$ ). Very little Ni (40 ppm maximum) was found. Up to $100 \mathrm{ppm}$ Ta and $600 \mathrm{ppm}$ Mo were found in their respective tests.

\section{Bi-U Fuel/Ternary Eutectic Tests}

Mo, 1020 mild steel, 21/4 Cr - 1 Mo steel, and type 446 stainless steel were not attacked after 1000-hr exposures to $\mathrm{Bi}-\mathrm{U} /$ ternary salt (Table 5 and Figures 16a, b, c). No corrosion was found after a 2500-hr test of 21/4 Cr - 1 Mo steel (Figure 16d).

Ta (Figure 16e) was transgranularly attacked. Previous tests at Ames Laboratory ${ }^{8}$ with $\mathrm{Bi}$ alone did not produce any significant attack at $1000^{\circ} \mathrm{C}$. 

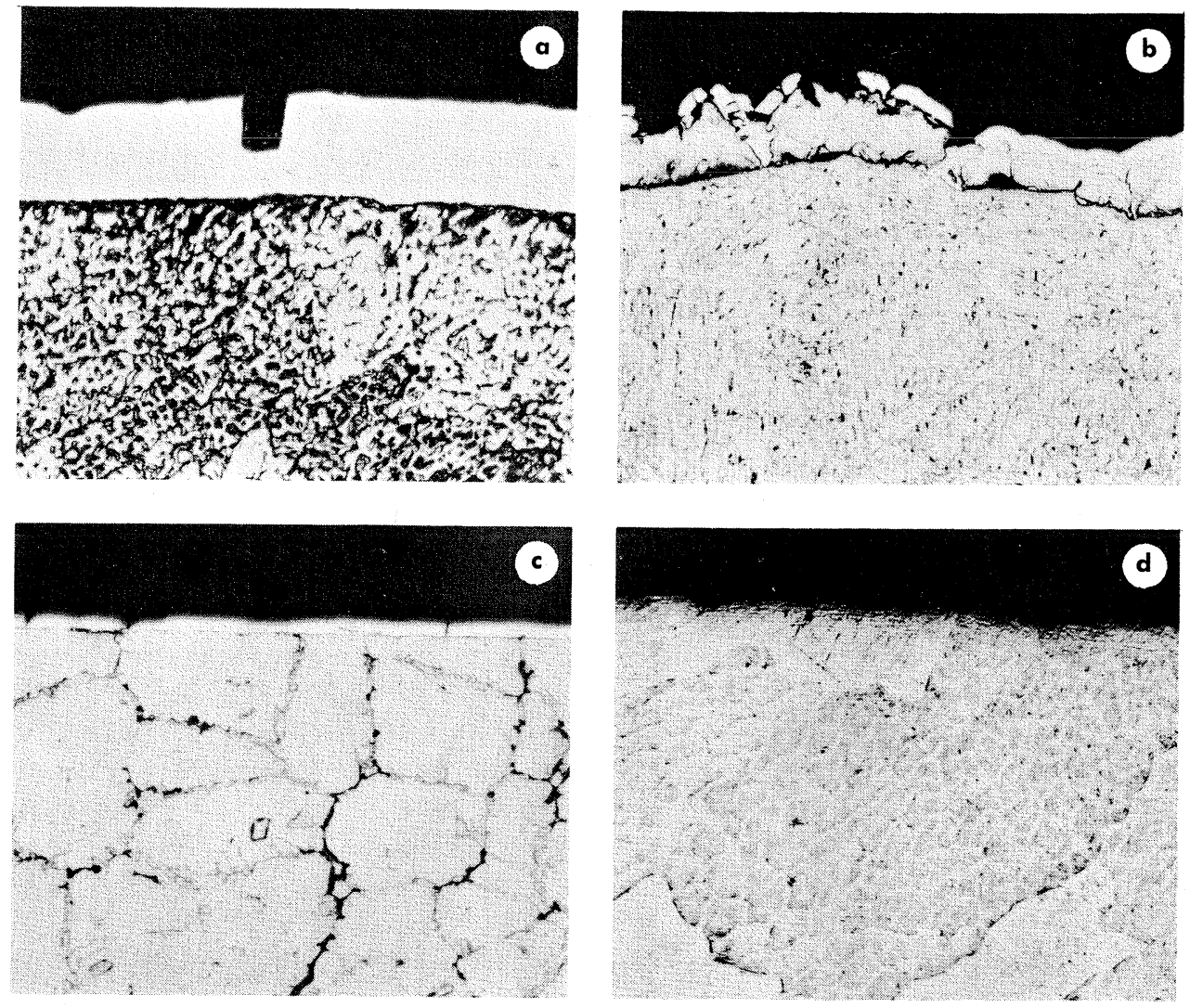

Figure 15. Photomicrographs $(250 \times)$ of fusion-welded specimens exposed to $\mathrm{NaCl}-\mathrm{KCl}-\mathrm{MgCl}_{2}$ eutectic for $1000 \mathrm{hr}$ in the tilting-furnace apparatus. Specimens located in hot ends of capsules with hot end at $500^{\circ} \mathrm{C}$ and cold end at $450^{\circ} \mathrm{C}$. (a) Section through surface of type 347 stainless steel weld (capsule D-20); Marbles etch. (b) Section through surface of $2^{1 / 4} \mathrm{Cr}-1$ Mo alloy steel weld (capsule J-23); nital etch. (c) Section through surface of type 446 stainless steel weld (capsule F-18); picric acid etch. (d) Section through surface of Inconel weld (capsule G-14); picric acid etch.

Type 446 (Figure 16c) was the only 400 series stainless steel that was not attacked. The corrosion resistance of type 430 stainless steel was like that of 16-1 Croloy [similar to type 431 (ELG) stainless steel]. Type 410 stainless steel (Figure 16f) was the least resistant in this series.

Figures $16 \mathrm{~g}, \mathrm{~h}$, and i show the appearance of type 347 stainless steel specimens as a function of surface treatment: mechanical polishing, electropolishing, and sandblasting.

Corrosion of the other materials was primarily intergranular. In most cases corrosion was accompanied by metallic deposition at the cold end, the deposition generally being greater with greater tab weight loss. The capsule and tab surfaces were generally found to be wetted by the Bi. No salt was found at the $\mathrm{Bi}$-capsule wall interface, which indicates that the salt may not creep into the $\mathrm{Bi}$ fuel system in a processing plant.

The corrosion occurring in the tilting-furnace tests with $\mathrm{Bi}-\mathrm{U} /$ ternary salt corrodents was similar in type and extent to that caused by Bi-U fuel in the absence of salt. Alloys containing Ni suffered severe attack, accompanied by significant weight losses and extensive mass transfer (Figures 16j, k). $\mathrm{Ni}$ is soluble in $\mathrm{Bi}$, and the corrosion was generally by intergranular attack. In the cases of types 304 (ELC) and 310 stainless steel and the high $\mathrm{Ni}$ alloys (Inconel, Inor-8, and Hastelloy C, this dissolution was so great that extensive transgranular attack also occurred.

$\mathrm{Fe}$ and $\mathrm{Ni}$ were the principal corrosion products found upon analysis of the corrodents from steel and $\mathrm{Ni}$ alloy capsules (see Appendix E). The Ni 

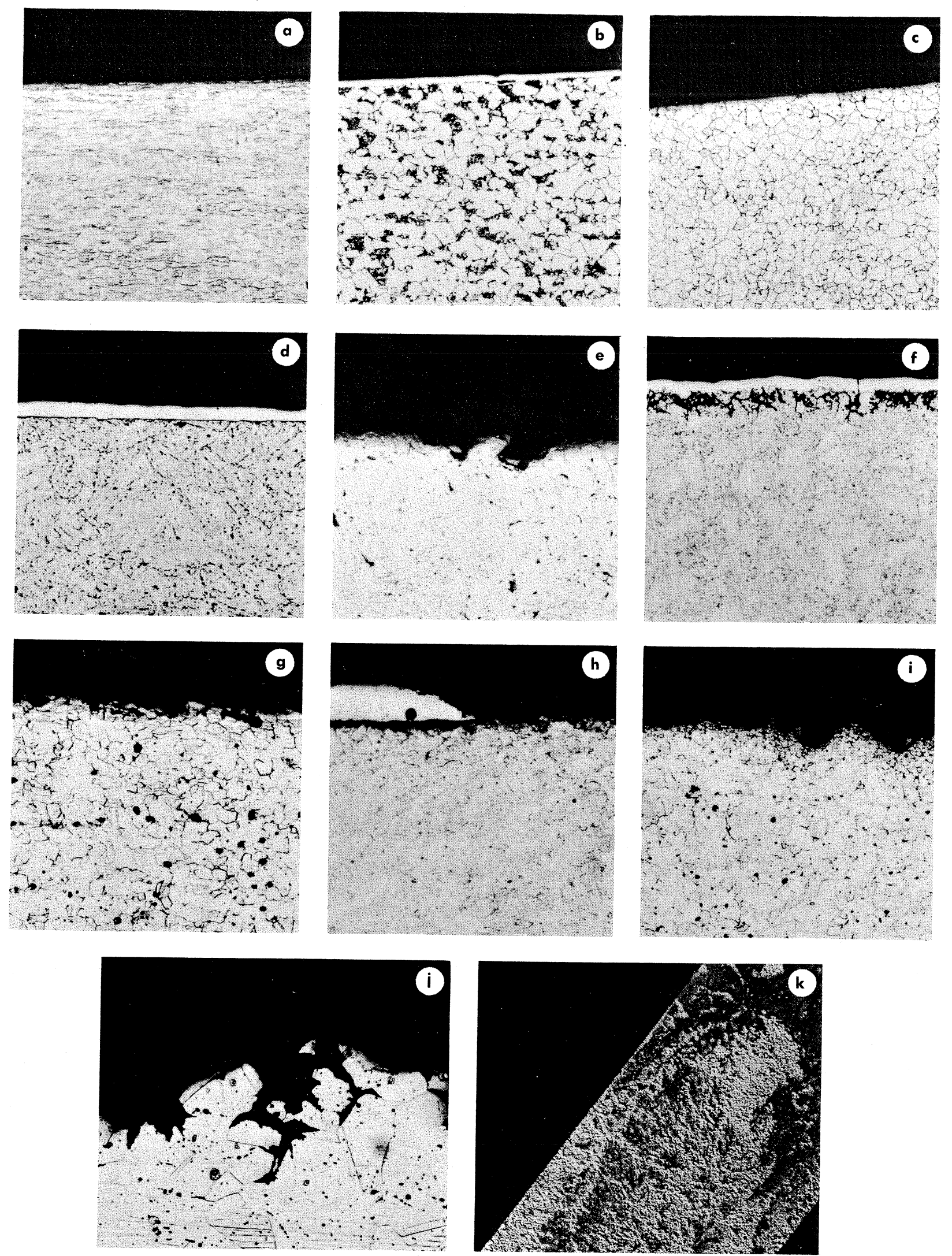

Figure 16. Photomicrographs $(250 \times)$ of specimens exposed to $\mathrm{NaCl}-\mathrm{KCl}-\mathrm{MgCl}_{2}$ and $\mathrm{Bi}-\mathrm{U}$ fuel in the tilting-furnace apparatus for $1000 \mathrm{hr}$ (except as noted otherwise). Capsule designation is given in parentheses. (a) Mo (K-11). Section through polished surface; etch: $\mathrm{K}_{3} \mathrm{Fe}(\mathrm{CN})_{6}, \mathrm{KOH}$ in $\mathrm{H}_{2} \mathrm{O}$. (b) 1020 mild steel (T-10). Section through polished surface; nital etch. (c) Type 446 stainless steel (F-10). Section through polished surface; etch: modified Carapella's reagent. (d) 21/4 Cr - 1 Mo alloy steel (J-15); 2500-hr exposure. Section through polished side of tab; nital etch. (e) Ta (L-12). Section through polished side of tab; etch: $\mathrm{HF}, \mathrm{HNO}_{3}$. (f) Type 410 stainless steel (E-11). Section through polished side of tab; etch: HCl, picric acid, alcohol. (g) Type 347 stainless steel (D-10). Section through polished side of tab; Marbles etch. (h) Type 347 stainless steel (D13). Section through electropolished tab; Marbles etch. (i) Type 347 stainless steel (D-10). Section through sandblasted side of tab; Marbles etch. (j) Inor-8 (P-10). Section through polished side of tab; aqua regia etch. (k) Hastelloy $\mathrm{C}(\mathrm{H}-11)$. Section through polished side of tab, $2.5 \times$. 
concentrated principally in the Bi phase (up to $1.65 \%$ ), while $\mathrm{Fe}$ was found primarily in the salt (up to $575 \mathrm{ppm}$ ). No Mo was found in the Bi and $<100 \mathrm{ppm}$ in the salt, while $30 \mathrm{ppm} \mathrm{Ta}$ was found in the $\mathrm{Bi}$ and $45 \mathrm{ppm}$ in the salt.

\section{Ternary Eutectic/ $\mathrm{BiCl}_{3}$ and $\mathrm{Bi}-\mathrm{U}$ Fuel/Ternary Eutectic/ $\mathrm{BiCl}_{3}$ Tests}

Mo and Ta were tested with a $4.76 \%$ solution of $\mathrm{BiCl}_{3}$ in ternary eutectic alone and in the presence of $\mathrm{Bi}-\mathrm{U}$ fuel. Au was tested with a $4.76 \%$ solution of $\mathrm{BiCl}_{3}$ in ternary eutectic alone. Because of experimental difficulties, not all the tests were of the same duration. The Mo and Ta were only slightly pitted or corroded transgranularly, although the $\mathrm{BiCl}_{3}$ was almost completely reduced. Only $\mathrm{Au}$ did not corrode significantly or reduce $\mathrm{BiCl}_{3}$ during these tests. See Figures 17 and 18 and Table 7 for details.

\section{THERMAL CONVECTION LOOP TESTS}

Mass transfer corrosion tests were performed in six thermal convection loops made of types 347 and 410 stainless steel and 21/4 Cr -1 Mo steel. Besides being larger than tilting-furnace capsules, these loops have the advantage that they may be sampled during the course of an experiment. Salt velocities comparable to those expected in a processing plant ( 0.2 to $0.3 \mathrm{ft} / \mathrm{sec})$ may be obtained.
All loops except F and L-1 were fabricated in the shape shown in Figure 19 from a 40-in. length of $1 / 2$-in. pipe. An 8 -in. length of 4 -in. pipe was placed at the top of the harp to serve as a surge tank. Loops F and L-1 were made from 72-in. lengths of $1 / 2$-in. pipe bent in a semicircular shape at the bottom. The surge tanks were made from 7 -in. lengths of 3- and 4-in. pipe, respectively. A 5 -in. test section was inserted in the upper portion of the hot leg. The test section, originally 6 in. long, was machined and polished on the inside. The dimensions of the section were recorded, and a 1-in. length was removed for use as a standard for comparison at the end of the run. An air lock with a sliding Teflon compression seal assembly and a $1 \frac{1}{2}$-in. ball valve was mounted on the surge tank. This chamber provided a means of taking samples from the loop during operation. Prior to construction, all materials were sandblasted except that in Loops F and L-1, which was electropolished. After fabrication, each loop was thoroughly cleaned with acetone and alcohol to remove moisture and grease. In addition, Loop L-7, which was constructed of $2^{1 / 4} \mathrm{Cr}-1$ Mo steel, was hydrogen-fired to remove oxides and moisture from the pipe walls. Hydrogen flow was stopped when a dew point of $-40^{\circ} \mathrm{C}$ was obtained at an average loop temperature of $550^{\circ} \mathrm{C}$. The loop was then purged with He.

A He mass spectrometer leak test was performed on each loop and its associated gas and

Table 7

Results of Tilting-Furnace Screening Tests* With $\mathrm{BiCl}_{3}$

Test temperature difference: $50^{\circ} \mathrm{C}\left(500^{\circ}-450^{\circ}\right)$

Corrodent: $\mathrm{NaCl}-\mathrm{KCl}-\mathrm{MgCl}_{2}$ eutectic plus $4.76 \% \mathrm{BiCl}_{3}$

\begin{tabular}{|c|c|c|c|c|c|}
\hline Material & $\begin{array}{l}\text { Length } \\
\text { of test, hr }\end{array}$ & $\begin{array}{l}\text { Type of corrosion } \\
\text { on polished side of tab }\end{array}$ & $\begin{array}{c}\text { Maximum } \\
\text { penetration, } \\
\text { mils/yr }\end{array}$ & $\begin{array}{l}\text { Weight change } \\
\text { of tab, } \mathrm{mg} / \mathrm{cm}^{2}-\mathrm{yr}\end{array}$ & $\begin{array}{l}\text { Residual \% } \\
\mathrm{BiCl}_{3} \text { in salt }\end{array}$ \\
\hline Molybdenum & 600 & Pitting & 2.2 & Not measured & $<0.05$ \\
\hline Tantalum & 1600 & Pitting & 1.4 & -45 & $<0.05$ \\
\hline \multirow[t]{2}{*}{ Gold } & 1000 & Intergranular & 1.0 & -1.1 & 4.92 \\
\hline & \multicolumn{5}{|c|}{ Corrodent: $\mathrm{Bi}-\mathrm{U}$ fuel/ternary eutectic plus $4.76 \% \mathrm{BiCl}_{3}$} \\
\hline Molybdenum & 2500 & Transgranular & 1.8 & -1.1 & 0.24 \\
\hline Tantalum & 2500 & Transgranular & 1.8 & -7.9 & 0.15 \\
\hline
\end{tabular}

${ }^{*}$ Results are averages of 2 tests. 

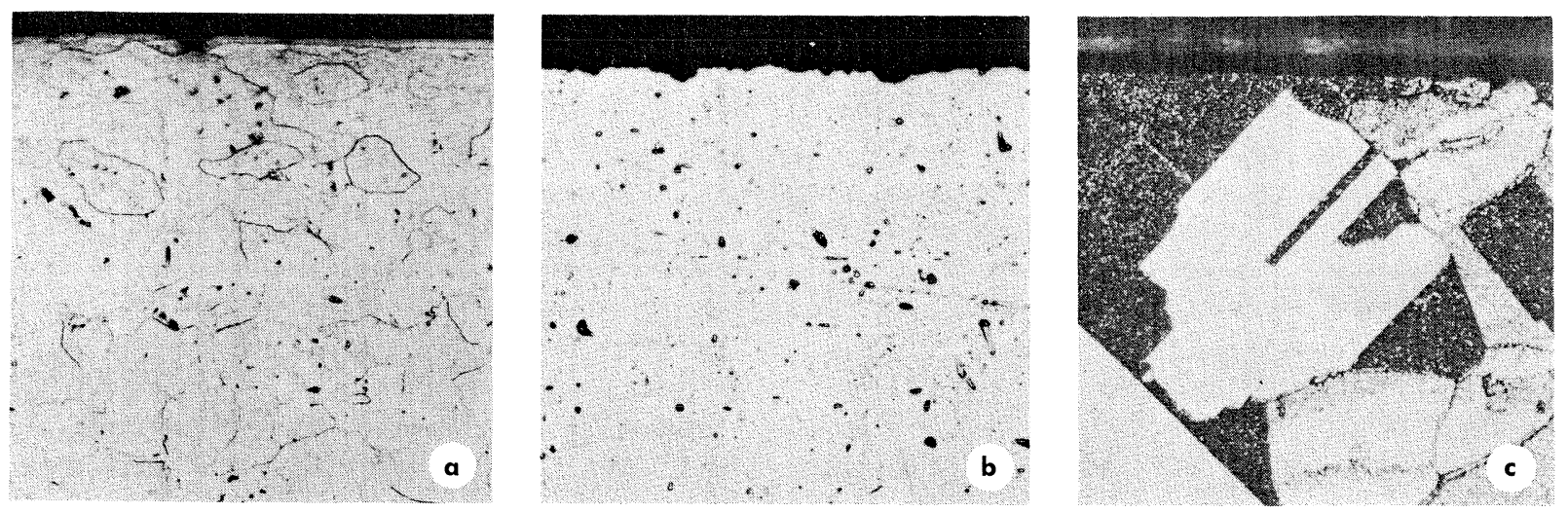

Figure 17. Photomicrographs $(250 \times)$ of tabs exposed to $\mathrm{NaCl}-\mathrm{KCl}-\mathrm{MgCl}_{2}$ eutectic containing $5 \% \mathrm{BiCl}_{3}$ in the tilting-furnace apparatus. (a) Mo (capsule $\mathrm{K}-17$ ). Section through polished side of tab; 600-hr exposure; etch: $\mathrm{K}_{3} \mathrm{Fe}(\mathrm{CN})_{6}, \mathrm{NaOH}$ in $\mathrm{H}_{2} \mathrm{O}$. (b) Ta (capsule L-23). Tab cleaned prior to exposure by degreasing only; 1600-hr exposure; etch: $\mathrm{HF}, \mathrm{NH}_{4} \mathrm{~F}$. (c) Au (capsule Au-1). Hot end of tab running full length of (glass) capsule; 1000-hr exposure; aqua regia etch.
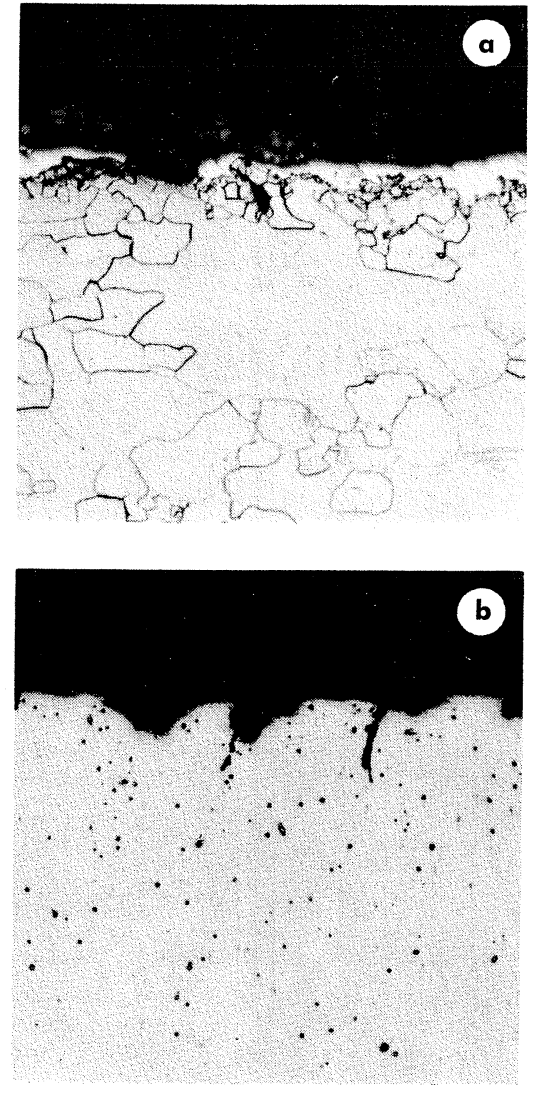

Figure 18. Photomicrographs $(250 \times)$ of tabs exposed to $\mathrm{Bi}-\mathrm{U}$ fuel and $\mathrm{NaCl}-\mathrm{KCl}-\mathrm{MgCl}_{2}$ eutectic containing $5 \%$ $\mathrm{BiCl}_{3}$ for $2500 \mathrm{hr}$ in the tilting-furnace apparatus. (a) Mo (capsule K-14). Section through polished side of tab; etch: $\mathrm{K}_{3} \mathrm{Fe}(\mathrm{CN})_{6}, \mathrm{NaOH}$ in $\mathrm{H}_{2} \mathrm{O}$. (b) Ta (capsule L-20). Tab cleaned prior to exposure by degreasing only; no etch.

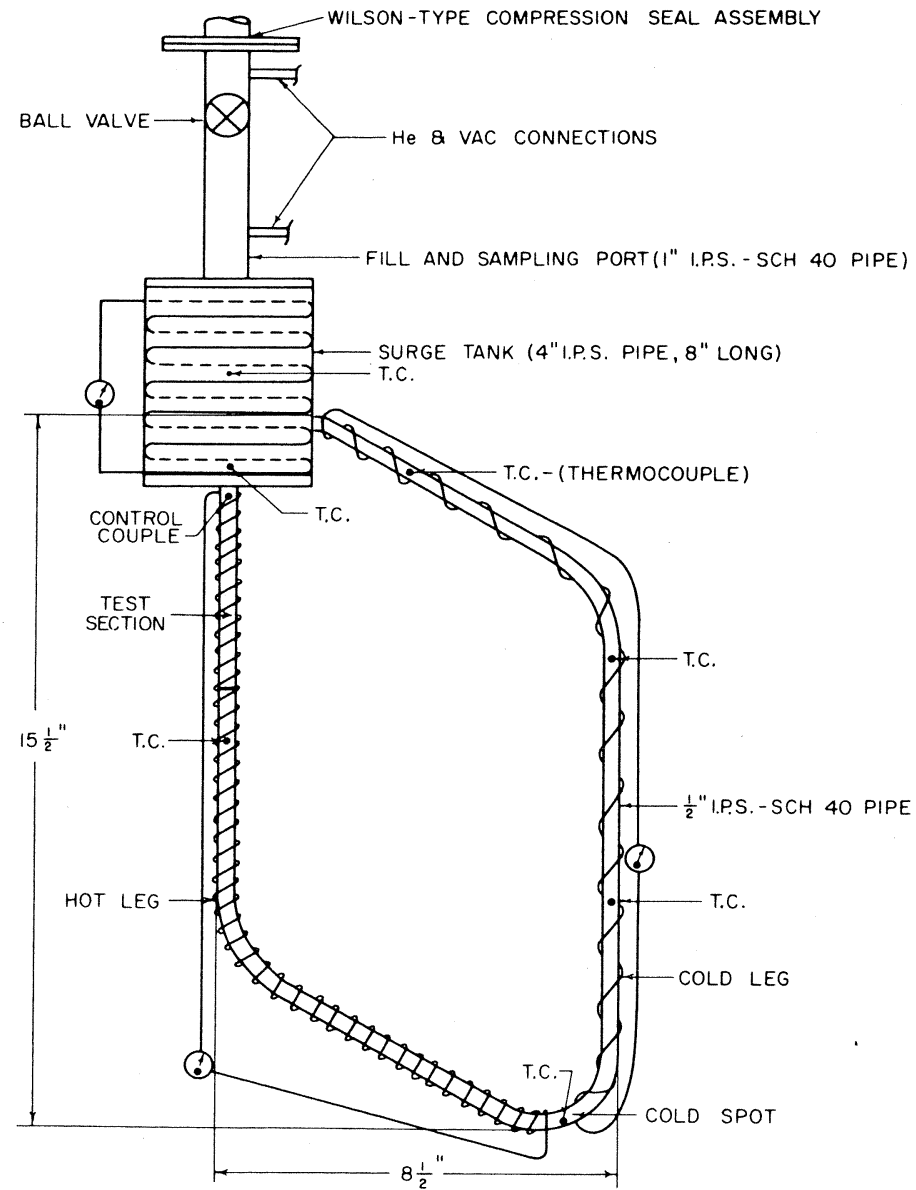

Figure 19. Schematic diagram of typical ternary salt thermal convection loop showing heater circuit windings and thermocouple measuring junction locations. 
vacuum piping before the installation of electric heating elements.

Three circuits of 20 gauge nichrome heater wire were used to heat each loop. The hot leg was wound with $25.2 \mathrm{ft}$ of wire in closely spaced turns and the surge tank with $23.3 \mathrm{ft}$ of wire. A 1-in. space containing no heater wire provided a cold spot on the cold leg. The 15-ft length of wire used on the remainder of the cold leg was applied in widely spaced turns. Loops F and L-1 were each wrapped with $41 \mathrm{ft}$ of wire on the hot legs, $8 \mathrm{ft}$ on the cold legs, and three 200-w strip heaters on the surge tank.

Eight thermocouples were used to determine pipe surface temperatures on each loop; 18 were used on Loops F and L-1. The maximum loop temperature was monitored by a thermocouple located on the hot leg just below the surge tank, and the minimum by one at the cold spot. The other thermocouples were placed around the rest of the loop.

All portions of the loop were insulated with 21/2 in. of Owens-Corning Kaylo. A separate block of insulation was used on the cold leg to permit easy removal during operation.

Each loop was degassed before charging with salt by heating under vacuum at a rate such that the pressure remained below $5 \mu \mathrm{Hg}$. A final pressure of $<1 \mu \mathrm{Hg}$ was obtained at $550^{\circ} \mathrm{C}$. The temperature was then lowered to $500^{\circ} \mathrm{C}$ and the loop pressurized to 5 psig with He.

Each ternary salt loop was charged with 2550 $\mathrm{g}$ of the eutectic. The salt was introduced into a loop by inserting a salt-filled glass tube (open at

Table 8

Results of Thermal Convection and Forced Convection Loop Corrosion Tests

\begin{tabular}{|c|c|c|c|}
\hline & \multicolumn{3}{|c|}{$\begin{array}{l}\text { Corrodent: LiCl-KCl Eutectic } \\
\text { Thermal convection loops }\end{array}$} \\
\hline & Loop F & Loop L-1 & Loop L-3 \\
\hline Material & 347 S.S. & 410 S.S. & $2^{1 / 4} \mathrm{Cr}-1 \mathrm{Mo}$ \\
\hline Operating time, hr & 5500 & 2200 & 697 \\
\hline Max. salt temperature, ${ }^{\circ} \mathrm{C}$ & 575 & 570 & 550 \\
\hline Salt $\Delta T,{ }^{\circ} \mathrm{C}$ & 155 & 160 & 150 \\
\hline Calculated velocity, $\mathrm{ft} / \mathrm{sec}$ & 0.68 & 0.75 & 0.48 \\
\hline Type of corrosion & Intergranular & Transgranular & $*$ \\
\hline Max. attack, mils/yr & 0.5 & 2.1 & $*$ \\
\hline $\begin{array}{l}\text { Composition of deposited } \\
\text { material }\end{array}$ & None & $62 \% \mathrm{Fe}-38 \% \mathrm{Cr}$ & $*$ \\
\hline
\end{tabular}

Corrodent: $\mathrm{NaCl}-\mathrm{KCl}-\mathrm{MgCl}_{2}$ Eutectic

\begin{tabular}{|c|c|c|c|c|c|}
\hline \multirow{8}{*}{$\begin{array}{l}\text { Material } \\
\text { Operating time, } \mathrm{hr} \\
\text { Max. salt temperature, }{ }^{\circ} \mathrm{C} \\
\text { Salt } \Delta T,{ }^{\circ} \mathrm{C} \\
\text { Calculated velocity, } \mathrm{ft} / \mathrm{sec} \\
\text { Type of corrosion }\end{array}$} & \multicolumn{3}{|c|}{ Thermal convection loops } & \multirow{2}{*}{\multicolumn{2}{|c|}{$\frac{\text { Forced circulation loop }}{\text { Loop M }}$}} \\
\hline & \multirow{3}{*}{$\begin{array}{c}\text { Loop L-5 } \\
347 \text { S.S. } \\
2467\end{array}$} & \multirow{2}{*}{$\begin{array}{c}\text { Loop L-6 } \\
410 \text { S.S. }\end{array}$} & \multirow{2}{*}{$\frac{\text { Loop L-7 }}{2^{1 / 4} \mathrm{Cr}-1 \mathrm{Mo}}$} & & \\
\hline & & & & 347 & S. \\
\hline & & 3971 & 6281 & 1034 & 656 \\
\hline & 500 & 494 & 501 & 520 & 515 \\
\hline & 45 & 42 & 49 & Isothermal & Isothermal \\
\hline & 0.25 & 0.24 & 0.26 & 13.2 & $1.8-7.9$ \\
\hline & Intergranular & Transgranular & $\begin{array}{l}\text { Transgranular and } \\
\text { intergranular }\end{array}$ & Transgranular & Transgranular \\
\hline $\begin{array}{l}\text { Max. attack, mils/yr } \\
\text { Composition of deposited }\end{array}$ & 3.9 & 3.3 & 3.1 & 1.3 & $10.7 * *$ \\
\hline material & $\mathrm{Fe}-\mathrm{Cr}, 2 \% \mathrm{Ni}$ & $\mathrm{Fe}-10 \% \mathrm{Cr} \dagger$ & $\mathrm{Fe}-2 \% \mathrm{Cr}$ & - & - \\
\hline
\end{tabular}

*The loop could not be examined metallurgically because the pipe ruptured after accidental overheating.

**Pipe specimen surface was sandblasted prior to the test. All others in the table were mechanically polished.

†Loop plugged. 
the bottom) at room temperature into the air lock on the top of the loop. After purging of the lock with $\mathrm{He}$, the inverted glass tube was lowered into the heated surge tank where the salt melted and flowed out of the tube.

The binary salt loops were charged from a portable stainless steel melt tank through a flanged connection on the surge tank. $\mathrm{LiCl}$ and $\mathrm{KCl}$ were charged into the tank, dried, and melted under high vacuum. The molten eutectic was transferred by application of He pressure to the tank. Oxide impurities were removed by a porous $20-\mu$ stainless steel filter located in the transfer line.

$\mathrm{He}$, purified by passage through a silica gel drier and tubes of Ti chips held at $825^{\circ}$ to $850^{\circ} \mathrm{C}$, was used as the cover gas for each loop.

Accurate temperature control was imperative during operation of the loops. Three separate transformers, one for each heater circuit, were used.

After loading, loop temperatures were stabilized at $500^{\circ} \mathrm{C}$. Insulation was then removed from the cold leg. The hot leg temperature of each loop was controlled, and the cold leg and surge tank heaters were adjusted to give the desired temperature difference.

A flexible thermocouple probe was inserted through the sliding Teflon compression seal into the air lock. After purging with $\mathrm{He}$, the probe was inserted into the salt stream to obtain a bulk temperature profile of the loop. The bulk temperature of the hot leg was $\approx 2{ }^{\circ} \mathrm{C}$ lower than the adjacent pipe surface temperature. The surface temperature in the cold leg was $\approx 20^{\circ} \mathrm{C}$ below the corresponding bulk temperature.

Salt velocities obtained for any temperature difference were calculated from the following formula:

$$
V=\left[\frac{\Delta h\left(\rho_{\mathrm{c}}-\rho_{\mathrm{h}}\right) g D}{4 f L \rho_{\mathrm{av}}}\right]^{1 / 2}
$$

where

$$
\begin{aligned}
V= & \text { salt velocity, } \mathrm{ft} / \mathrm{sec} ; \\
\Delta h= & \text { difference in height between points of } \\
& \text { maximum and minimum loop tem- } \\
& \text { perature, } \mathrm{ft} ; \\
\rho_{\mathrm{h}}, \rho_{\mathrm{c}}, \rho_{\mathrm{av}}= & \text { salt densities }{ }^{9} \text { at maximum, minimum, } \\
& \text { and average temperature, } \mathrm{lb} / \mathrm{ft}^{3} ; \\
g= & \text { gravitational constant, } \mathrm{ft} / \mathrm{sec}^{2} ; \\
D= & \text { pipe diameter, } \mathrm{ft} ; \\
L= & \text { equivalent length of pipe, } \mathrm{ft} ; \text { and } \\
f= & \text { Fanning friction factor. }
\end{aligned}
$$

The ternary salt was generally sampled weekly with degassed graphite cups by the thief method ${ }^{10}$ and analyzed for $\mathrm{Fe}, \mathrm{Cr}, \mathrm{Mn}$, and $\mathrm{Ni}$. The binary salt loops were sampled only infrequently.

A radiograph of each ternary salt loop was taken weekly to observe corrosion and deposition changes. A 700 to $900-\mathrm{mC} \operatorname{Ir}^{192}$ source was used.

The results are shown in Table 8 and Appendix $\mathrm{F}$ and described below.

\section{Loop F}

This type 347 stainless steel, binary salt, thermal convection loop was shut down voluntarily after $5500 \mathrm{hr}$ of operation at a surface temperature difference of $155^{\circ} \mathrm{C}$ and a maximum hot leg surface temperature of $575^{\circ} \mathrm{C}$. The calculated velocity through the loop was $0.68 \mathrm{ft} / \mathrm{sec}$.

Metallurgical examination of the loop showed no plugging of the cold leg and a maximum intergranular corrosion of the hot leg of $\approx 0.3 \mathrm{mil}$.
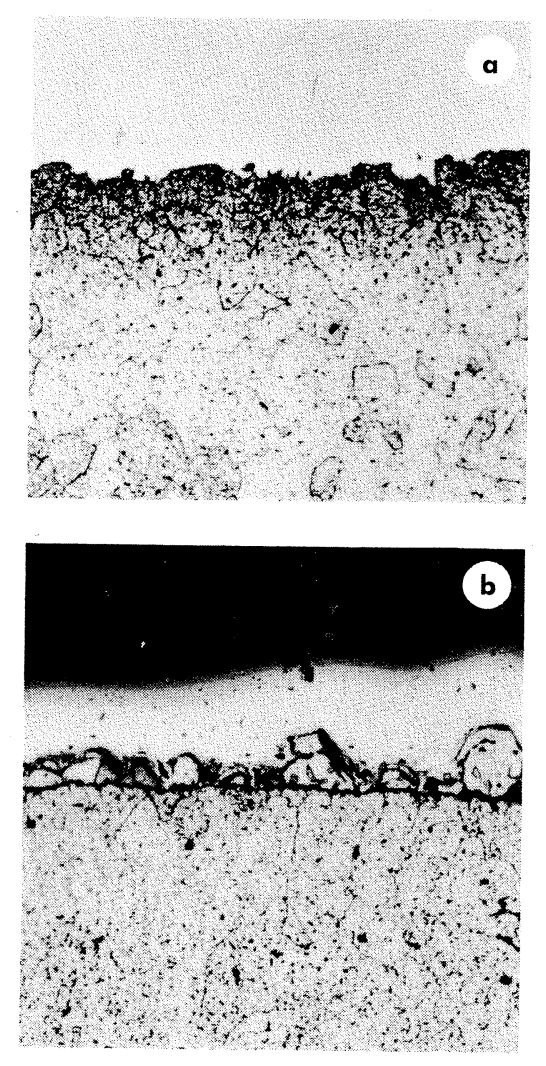

Figure 20. Photomicrographs $(250 \times)$ of portions of thermal convection Loop L-1 (type 410 stainless steel). HCl, picric acid, alcohol etch. (a) Hot leg test specimen showing intergranular attack. (b) Cold leg showing deposition of Fe-Cr particles. 


\section{Loop L-1}

This type 410 stainless steel, binary salt, thermal convection loop was operated for $2200 \mathrm{hr}$ at a surface temperature difference of $160^{\circ} \mathrm{C}$ and a maximum surface temperature of $570^{\circ} \mathrm{C}$. The calculated velocity through the loop was $0.75 \mathrm{ft} / \mathrm{sec}$. The loop was shut down because during start-up after a power failure melting of the salt produced a rupture in the wall of the hot leg.

Samples taken for corrosion product analysis during loop operation showed that the $\mathrm{Fe}$ concentration rose to $150 \mathrm{ppm}$ and $\mathrm{Mn}$ and $\mathrm{Cr}$ remained constant at 65 and $115 \mathrm{ppm}$ respectively. Ni was not detected (limit of detection $10 \mathrm{ppm}$ ). Salt samples taken from various parts of the loop after shutdown showed that the Fe concentration varied between 85 and $290 \mathrm{ppm}$, whereas the $\mathrm{Mn}$ and $\mathrm{Cr}$ concentrations were uniform at 50 and $10 \mathrm{ppm}$, respectively.

Metallographic examination of the loop showed the presence of considerable transgranular corrosion of the hot leg (0.5 mil deep; see Figure 20a), and the start of an Fe-Cr plug in the cold leg (Figure $20 \mathrm{~b}$ ) analyzed as $62 \% \mathrm{Fe}$ and $38 \% \mathrm{Cr}$. Although the loop was shut down because of a mechanical mishap, it would have been only a short time before the cold leg deposition plugged the pipe. On the basis of this experiment, the use of type 410 stainless steel appears to be unsatisfactory for $\mathrm{LiCl}-\mathrm{KCl}$ eutectic service.

\section{Loop L-3}

This $21 / 4 \mathrm{Cr}-1$ Mo steel, binary salt, thermal convection loop was operated with a surface tem-

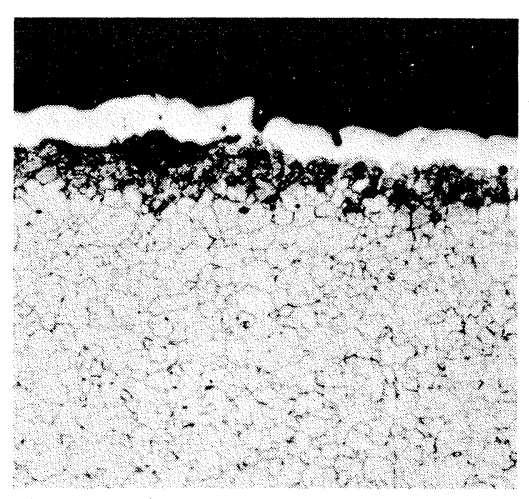

Figure 21. Photomicrograph $(250 \times)$ of portion of hot leg from thermal convection Loop L-5 (type 347 stainless steel) showing intergranular corrosion. Marbles etch. perature difference of $150^{\circ} \mathrm{C}$ and a hot leg surface temperature of $550^{\circ} \mathrm{C}$. The loop was shut down after $697 \mathrm{hr}$ of operation at a calculated velocity of $0.48 \mathrm{ft} / \mathrm{sec}$ when the hot leg temperature had risen sharply because the temperature controller failed to function. In the attempt to restart the loop, the pipe wall was ruptured as a result of uneven expansion of the salt. Because of the rupture, metallurgical examination of the loop was impossible. Radiographic inspection indicated a plug in the cold spot of the loop.

Only one sample was obtained during loop operation. After $210 \mathrm{hr}$ of operation, chemical analysis showed the following concentrations of corrosion products: Fe, 1100 ppm; Mn, 95 ppm; Cr, 20 ppm; and Mo, maximum 50 ppm.

\section{Loop L-5}

This type 347 stainless steel, ternary salt, thermal convection loop was operated for $2467 \mathrm{hr}$ with maximum bulk temperatures of $500^{\circ}$ and $504^{\circ} \mathrm{C}$. The corresponding bulk temperature differences of $41^{\circ}$ and $54^{\circ} \mathrm{C}$ were maintained for 1030 and $1344 \mathrm{hr}$, respectively. Velocities through the loop were 0.22 and $0.27 \mathrm{ft} / \mathrm{sec}$, respectively.

The loop operated satisfactorily until a graphite sampling cup was accidentally dropped into the surge tank, causing the temperature difference to increase to $69^{\circ} \mathrm{C}$ with a maximum temperature of $524^{\circ} \mathrm{C}$. After $93 \mathrm{hr}$ of operation at this temperature, the loop was shut down. Radiographic inspection during operation and after shutdown indicated no apparent corrosion in the hot leg and no deposition in the cold leg.

The results of the chemical analysis for corrosion products in salt samples taken twice weekly are as follows: After an initial increase to $50 \mathrm{ppm}$ within the first $100 \mathrm{hr}$, the $\mathrm{Cr}$ concentration increased at a constant rate to $375 \mathrm{ppm}$ at the conclusion of the test. The Mn concentration increased to $25 \mathrm{ppm}$ at $1300 \mathrm{hr}$ and thereafter remained constant. Ni was not detected (limit of detection $10 \mathrm{ppm}$ ). The Fe concentration was erratic, reaching values as high as $300 \mathrm{ppm}$.

Metallographic examination of the loop showed the presence of a very small amount of intergranular corrosion ( $<1$ mil deep) in the hot leg (Figure 21 ), whereas none was observed on the machined standard hot test specimen. Slight deposition was observed in the cold leg. The deposit was removed and identified by spectrographic analysis as an $\mathrm{Fe}$ Cr alloy containing $\approx 2 \% \mathrm{Ni}$. 

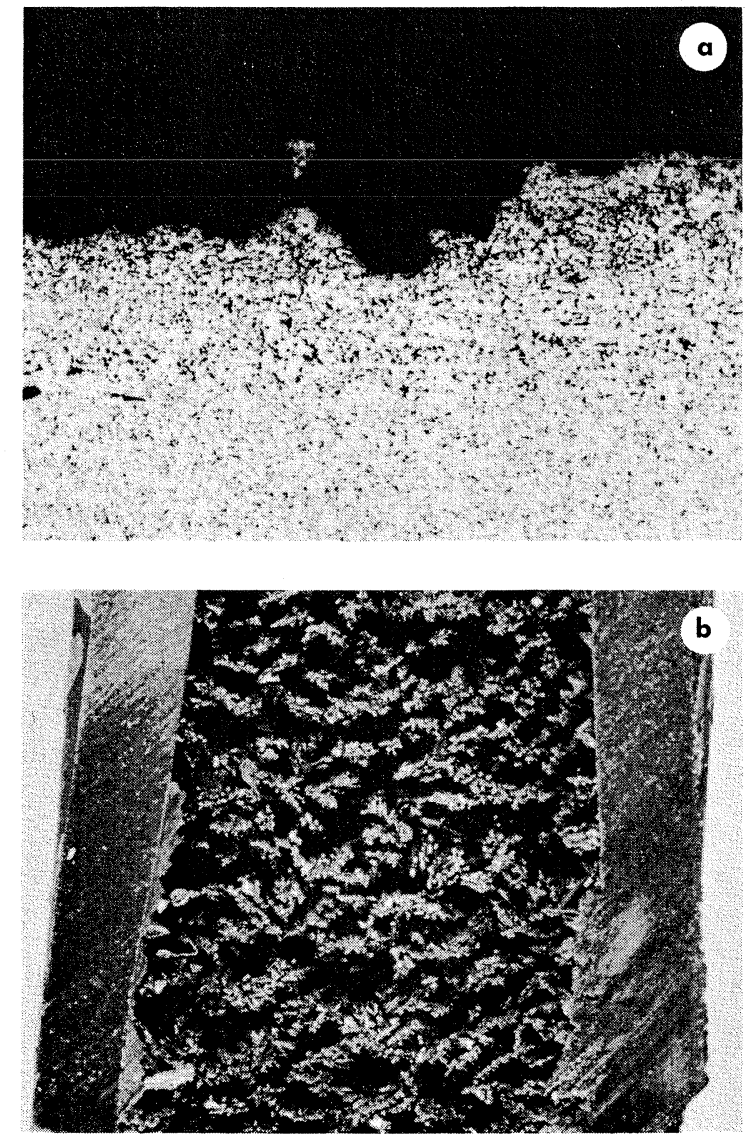

Figure 22. Photomicrographs of portion of thermal convection Loop L-6 (type 410 stainless steel). (a) Hot leg, showing transgranular corrosion; $\mathrm{HCl}$, picric acid, alcohol etch $(250 \times)$. (b) Dense Fe $-10 \%$ Cr deposit in cold leg $(3 \times)$.

\section{Loop L-6}

This type 410 stainless steel, ternary salt, thermal convection loop was shut down after $3971 \mathrm{hr}$ of operation at a bulk temperature difference of $42^{\circ} \mathrm{C}$ and a maximum bulk temperature of $494^{\circ}$ C. The maximum velocity through the loop was $0.24 \mathrm{ft} / \mathrm{sec}$. Radiographic inspection of the loop indicated no corrosion in the hot leg and some deposition in the cold leg. The deposition was first detected after $1400 \mathrm{hr}$ and increased steadily throughout the remainder of the run. The loop was shut down when the deposition restricted the salt flow so that the cold leg froze and the hot leg reached a maximum temperature of $550^{\circ} \mathrm{C}$.

Corrosion product concentrations in the salt were as follows: The Fe content increased from 10 to $700 \mathrm{ppm}$ in the first $1400 \mathrm{hr}$ and then remained constant until $3000 \mathrm{hr}$. At that time, an unex- plained decrease to $450 \mathrm{ppm}$ occurred, and the concentrations remained constant until shutdown. The Gr content increased at a constant rate to a value $>1000 \mathrm{ppm}$. Mn increased to $80 \mathrm{ppm}$, and $\mathrm{Ni}$ was not detected (limit of detection $10 \mathrm{ppm}$ ).

Metallographic inspection of the loop revealed a slight amount of transgranular corrosion in a small area of the hot leg (Figure 22a), the maximum attack being $\approx 1.5$ mils. Welds appeared to be unaffected by the salt. Deposition was found at the bottom of the cold leg extending over an area of $\approx 3$ in. $^{2}$ (Figure 22b). Chemical analysis showed that this material consisted of a dense $\mathrm{Fe}-\mathrm{Cr}$ alloy containing $10 \% \mathrm{Cr}$. Study of the surge tank wall indicated no direct attack; however, the area below the salt level appeared to be free of any scale, whereas above this level scale was evident. At the salt-to-He interface, a 1/4-in. ridge of $\mathrm{Fe}-\mathrm{Cr}$ alloy was found adhering to the wall of the tank, which had the same general structure as the other plug material found in the loop.

\section{Loop L-7}

This $21 / 4 \mathrm{Cr}-1$ Mo steel, ternary salt, thermal convection loop was operated for $6281 \mathrm{hr}$ before it was shut down voluntarily. Bulk temperature differences of $57^{\circ}$ and $49^{\circ} \mathrm{C}$ with maximum bulk temperatures of $511^{\circ}$ and $501^{\circ} \mathrm{C}$ were maintained for 545 and $5736 \mathrm{hr}$, respectively. Calculated velocities through the loop were $0.33 \mathrm{ft} / \mathrm{sec}$ for 545 $\mathrm{hr}$ and $0.26 \mathrm{ft} / \mathrm{sec}$ for $5736 \mathrm{hr}$. Prior to start-up, the loop was cleaned by hydrogen-firing at $550^{\circ} \mathrm{C}$ in addition to sandblasting as in Loops L-5 and L-6. Radiographic inspection during operation and after shutdown indicated no apparent corrosion in the hot leg and steadily increasing deposition in the cold leg after $2600 \mathrm{hr}$ of operation.

The results of the corrosion product analysis are as follows. The Fe concentration increased in stepwise fashion: it went from 10 to $1440 \mathrm{ppm}$ in the first $2100 \mathrm{hr}$ of operation, remaining at $1440 \mathrm{ppm}$ up to $4100 \mathrm{hr}$; it increased to $1750 \mathrm{ppm}$ by 4550 $\mathrm{hr}$, remaining at this value up to $5900 \mathrm{hr}$; and it increased finally to $2100 \mathrm{ppm}$, where it remained until shutdown. Cr, which was not detected for the first $700 \mathrm{hr}$, increased to $210 \mathrm{ppm}$ after $2700 \mathrm{hr}$ of operation; it then increased rapidly to $580 \mathrm{ppm}$, where it remained constant until $3600 \mathrm{hr}$, at which point it decreased unexplainably to 400 $\mathrm{ppm}$ for the remainder of the run. The $\mathrm{Mn}$ increased to $140 \mathrm{ppm}$ after $3150 \mathrm{hr}$ of operation and remained at this value until $3600 \mathrm{hr}$, when it de- 

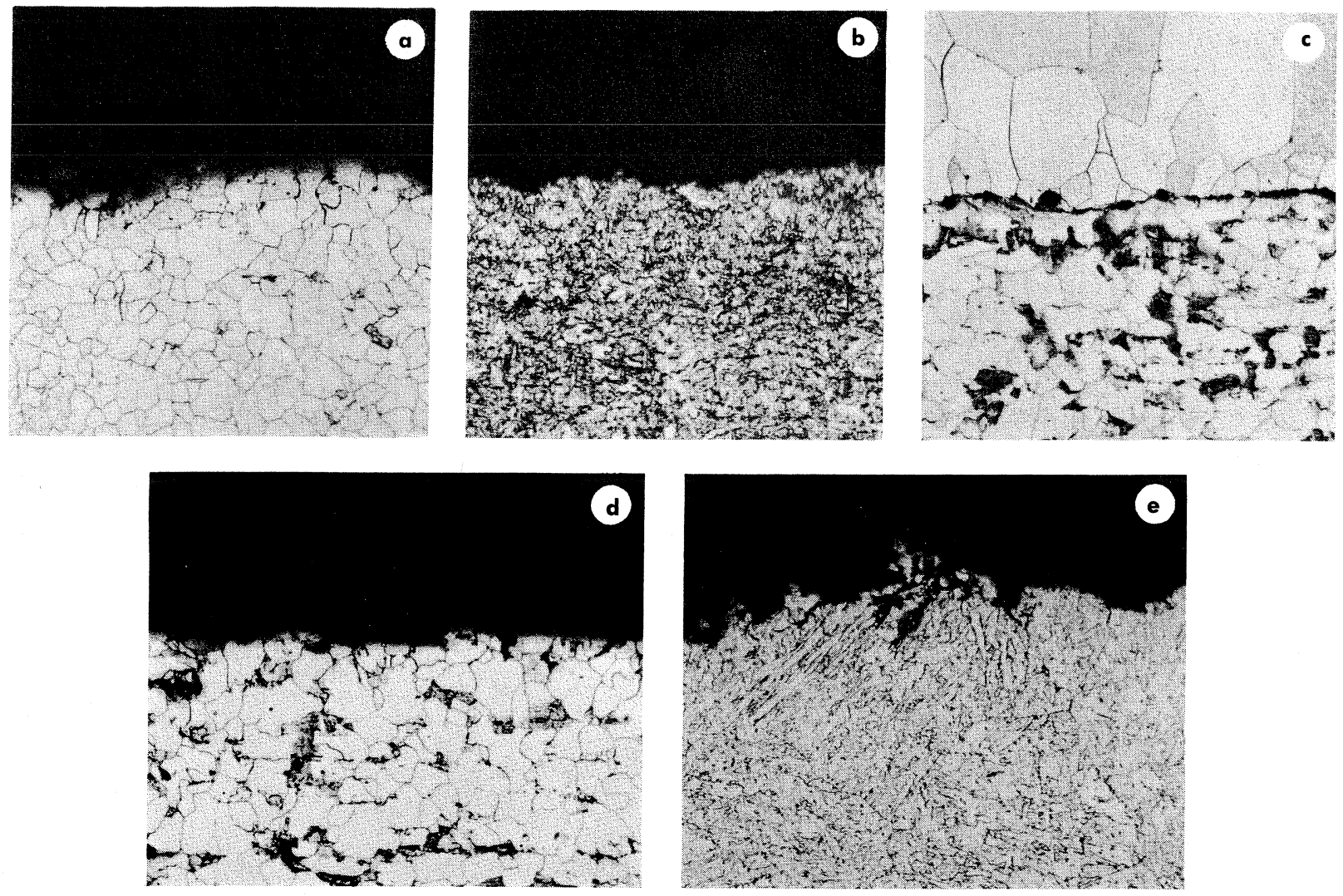

Figure 23. Photomicrographs $(250 \times)$ of portions of thermal convection Loop L-7 (21/4 Cr -1 Mo alloy steel). Nital etch. (a) Corrosion at bottom of surge tank. (b) Polished test specimen showing transgranular and slight intergranular corrosion. (c) Deposition and slight corrosion of section of pipe between surge tank and cold leg. (d) Corrosion at bottom of cold leg. (e) Corrosion of a weld.

creased for an unknown reason to $60 \mathrm{ppm}$; it then increased slowly to its final concentration of 95 ppm. Ni was not detected (limit of detection 10 ppm).

Visual inspection of the loop revealed no extensive corrosion. Microscopic examination showed a general state of transgranular and slight intergranular corrosion throughout the loop and surge tank (Figure 23). Corrosion in the lower section of the hot leg reached a maximum depth of 2.2 mils and an average attack of 1.5 mils. The polished standard section showed corrosion from $0.8 \mathrm{mil}$ average to 1 mil maximum. The pipe leading from the surge tank to the cold leg exhibited an average attack of 0.8 mil and a maximum of 1.9 mils. Corrosion was also evident in the bottom of the cold leg, where attack reached a maximum of 1.5 mils and an average of 1 mil. Deposition was noted in several areas of the cold leg and throughout the hot leg. Chemical analysis showed the plug material to be principally $\mathrm{Fe}$ combined with $\approx 2 \% \mathrm{Cr}$.

The weld corrosion was not significantly greater than that in any other region in the loop. Maximum attack was 2.4 mils.

The corrosion in the loop tests was low, and welds were not preferentially attacked in any of them. The highly polished test specimen surfaces corroded appreciably less than the corresponding pipe surfaces which had been sandblasted prior to assembly. The compositions of the deposits were similar to those of the original steel.

\section{FORCED CIRCULATION LOOP TEST}

Some information on corrosion by the ternary eutectic was obtained from the operation of a mechanical components test loop (Figure 24) made of type 347 stainless steel. The loop was operated iso- 


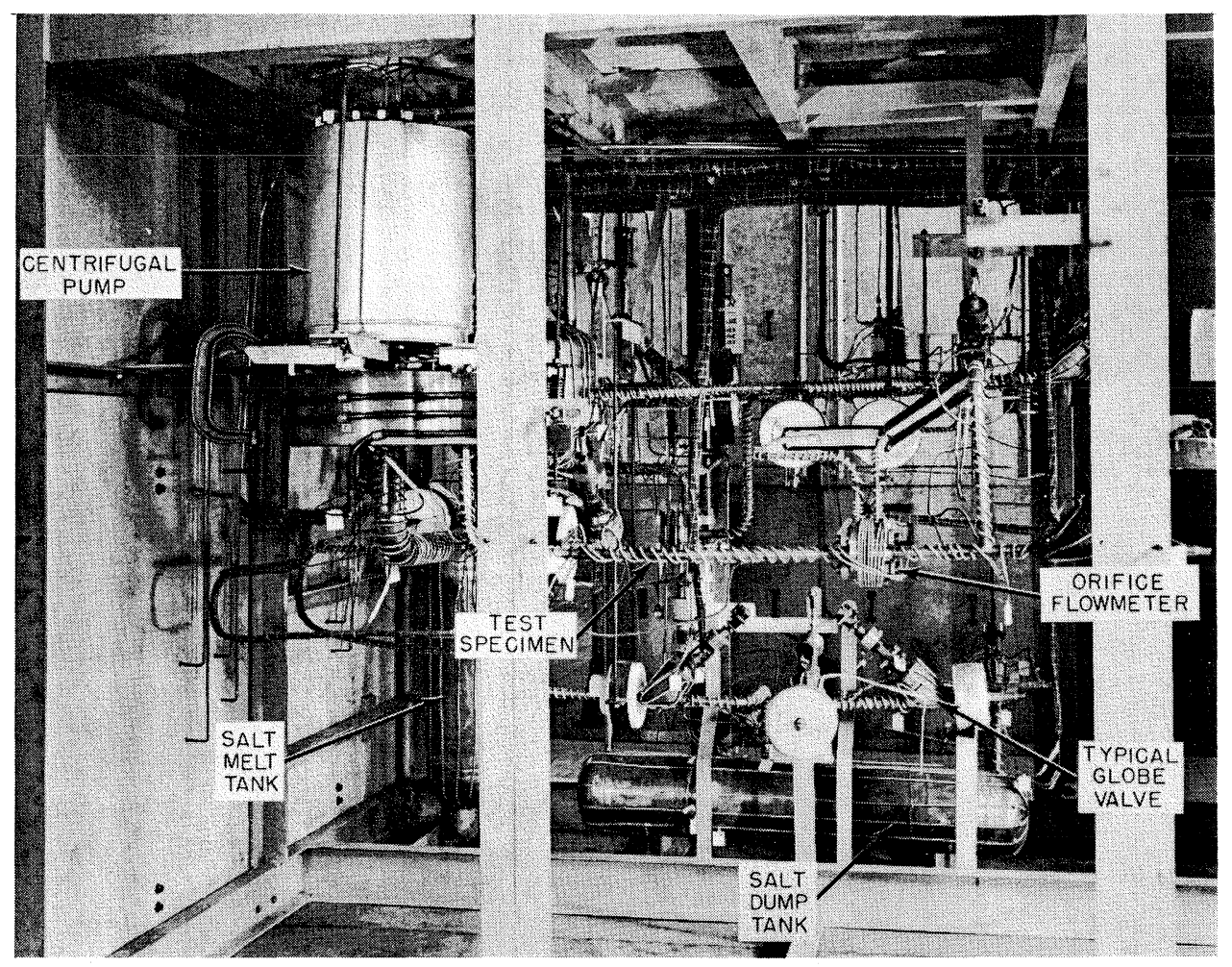

Figure 24. Photograph of fused salt forced circulation

Loop $\mathrm{M}$ taken prior to application of insulation.

thermally at velocities of 2 to $13 \mathrm{ft} / \mathrm{sec}$. In the first of two tests (see Table 8), which were primarily pump tests, the salt was circulated for $1034 \mathrm{hr}$ at $520^{\circ} \mathrm{C}$ and a maximum velocity of $13.2 \mathrm{ft} / \mathrm{sec}$. Upon conclusion of the test, a $1 / 2$-in. IPS polished test specimen was removed from the loop and examined metallographically. Slight transgranular attack ( 1.3 mils/year maximum penetration) was found (Figure 25a).

The loop was sampled periodically during the first run, and the salt was analyzed for corrosion products. The Ni concentration remained constant at $10 \mathrm{ppm}$ for the entire test, and the $\mathrm{Mn}$ concentration increased slightly from 10 to 21 ppm. The $\mathrm{Cr}$ concentration increased rapidly from 23 to $90 \mathrm{ppm}$ in the first $80 \mathrm{hr}$ and then more slowly to $155 \mathrm{ppm}$, and Fe increased from 10 to 800 ppm.

In the second test the salt was circulated for 656 hr at $515^{\circ} \mathrm{C}$ at velocities varying from 1.8 to 7.9 $\mathrm{ft} / \mathrm{sec}$. A section of $1 / 2$-in. pipe, whose surface had been sandblasted during fabrication, was removed and examined. Transgranular attack (10.8 mils/ year maximum penetration) was found (Figure
$25 \mathrm{~b})$. As in the case of the thermal convection loops, the corrosion of highly polished metal surfaces in this loop was appreciably less than that of sandblasted ones.

\section{SUMMARY OF RESULTS}

The $\mathrm{NaCl}-\mathrm{KCl}-\mathrm{MgCl}_{2}$ eutectic by itself was tested in all apparatus types with a wide variety of metallic materials and some ceramics. With few exceptions, it produced little corrosion. Weld areas were not preferentially attacked. The extent of mass transfer attack by the eutectic was negligible in 1000-hr tilting-furnace capsule tests, but plugging did occur in the type 410 stainless steel thermal convection loop after $4000 \mathrm{hr}$ of operation. Little or no $\mathrm{Ni}$ was found in corrodent analyses in any of the tests of Ni-bearing alloys. This suggests that further studies might show high Ni alloys to be superior to all others tested here.

The tests reported here do not clearly show a superior container material or particular range of superior container material compositions for the ternary eutectic. Hence, a wide variety of materi- 

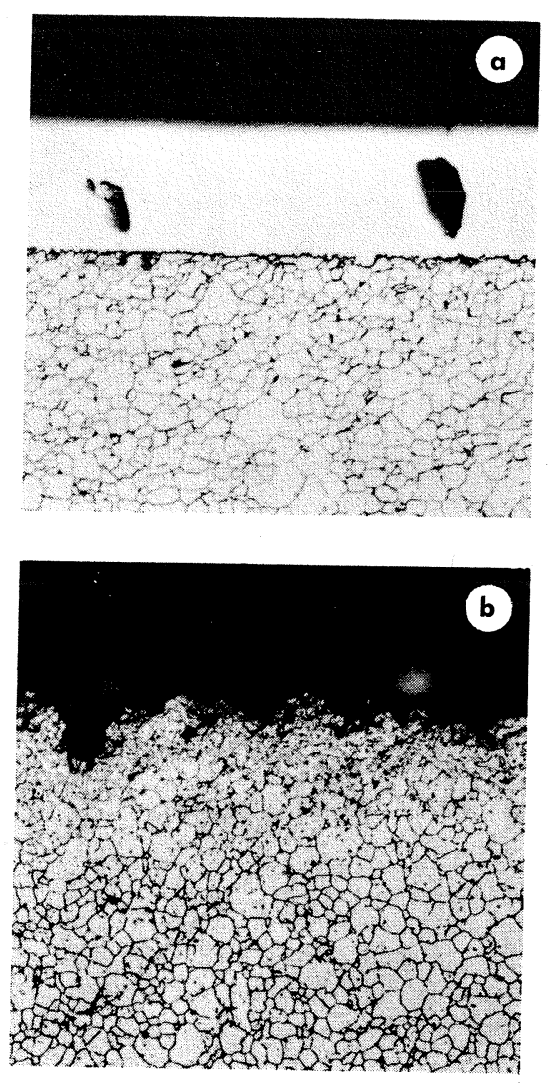

Figure 25. Photomicrographs $(250 \times)$ of portions of forced circulation Loop M (type 347 stainless steel). Marbles etch. (a) Surface of polished test section. (b) Surface of $1 / 2$-in. pipe.

als is available for further study and experimental use.

The fact that the ternary eutectic produced little corrosion, plus the observation that on completion of the tests there was generally no evidence of discoloration due to rust within the test apparatus, indicates that the methods of corrodent purification and handling were effective and that the different types of apparatus were leak tight.

Corrosion by the liquid metal - fused ternary salt system in the absence of $\mathrm{BiCl}_{3}$ resembled that expected in the presence of fuel alone. Alloys resistant to fuel were found to be resistant to fuel in the presence of salt. The selection of a container material for the two-phase system thus appears to hinge on the selection of a container material for fuel. At present, 1020 mild steel, 11/4 Cr - 1/2 Mo, or $21 / 4 \mathrm{Cr}-1 \mathrm{Mo}$ are most likely to be used for this purpose.

The facts that, on completion of the experiments, the container surfaces were found to be wetted by the $\mathrm{Bi}$, and salt was never found at the $\mathrm{Bi}$-container interface, suggest that creep of salt into the fuel system via such interfaces will probably not occur in a processing plant.

In the presence of liquid metal fuel and $5 \%$ $\mathrm{BiCl}_{3}$ in ternary eutectic, both materials tested, Mo and Ta, were subject to transgranular attack, and the $\mathrm{BiCl}_{3}$ was almost completely reduced. However, in these tests $\mathrm{BiCl}_{3}$ was present stoichiometrically in excess of the oxidizable fuel solutes, $\mathrm{U}, \mathrm{Mg}$, and $\mathrm{Zr}$. When $\mathrm{U}, \mathrm{Mg}$, and $\mathrm{Zr}$ are present in stoichiometric excess of $\mathrm{BiCl}_{3}$, it has been found in other work at Brookhaven ${ }^{11}$ that the fuel solutes are oxidized and not the container material. This has been found to be true in repeated experiments involving type 347 stainless steel and Mo containers. Thus it appears that contacting vessels in a processing plant in which $\mathrm{BiCl}_{3}$ will be present may be made of materials selected primarily for resistance to fuel, as long as $\mathrm{BiCl}_{3}$ is not in excess of oxidizable fuel solutes. Such is the case in the process flow sheet (Figure 1).

The principal corrosion problem in the process appears to be that of containing solutions of $\mathrm{BiCl}_{3}$ in eutectic from the point of make-up to the point of consumption. Although $\mathrm{Al}_{2} \mathrm{O}_{3}$ and $\mathrm{Au}$ withstood attack by this corrodent in capsule experiments, further experiments, on a larger scale, would be required before they could be recommended as practical materials of construction.

In all tests, mechanically polished surfaces generally withstood attack better than sandblasted surfaces.

The LiCl-KCl eutectic was tested by itself in a few early experiments involving static capsules and thermal convection loops. Like the ternary eutectic, it proved to be a mild corrodent.

\section{ACKNOWLEDGMENTS}

The authors gratefully acknowledge the contributions of the following Brookhaven National Laboratory staff members and groups: G. Farber and $W$. Hansen in the development of experimental techniques and for conducting experiments; O.E. Dwyer and J.R. Weeks for their helpful suggestions and advice; the Metallography Section for examining the corrosion specimens; and the Hot Laboratory Radiochemical Analysis Section for analyzing the corrodents. The ceramic and Inor-8 test materials were supplied by the Norton Company and Oak Ridge National Laboratory, respectively. 


\section{REFERENCES}

1. O.E. Dwyer, A.M. Eshaya, and F.B. Hill, Continuous removal of fission products from uranium-bismuth reactor fuels, Proc. 2nd UN Intern. Conf. on Peaceful Uses of Atomic Energy, Vol. 17, pp. 428-37, UN, Geneva, 1958.

2. Report of the Fluid Fuel Reactors Task Force to the Division of Reactor Development, US AEC, TID-8507, Feb. 1959.

3. D.W. Bareis, A Continuous Fission Product Separation Process. 1. Removal of the Rare Earths (Lanthanum, Praseodymium and Neodymium) from a Typical Liquid BismuthUranium Reactor Fuel by Contact with Fused LiCl-KCl Mixtures, LFR-3, BNL 125, July 1951, Declassified March 1957.

4. C. J. Klamut, D.G. Schweitzer, J.G.Y. Ghow, R.A. Meyer, O.F. Kammerer, J.R. Weeks, and D.H. Gurinsky, Material and fuel technology for an LMFR, Proc. 2nd UN Intern. Conf. on Peaceful Uses of Atomic Energy, Vol. 7, pp. 173-95, UN, Geneva, 1958.

5. J.H. Jackson and M.H. LAChance, Resistance of cast $\mathrm{Fe}-\mathrm{Ni}$ - $\mathrm{Cr}$ alloys to corrosion in molten neutral heat treating salts, Trans. Am. Soc. Metals 46, 157-83 (1954).

6. M.A. Bredig, J.W. Johnson, And W.T. Smith JR., Miscibility of liquid metals with salts. I. The sodiumsodium halide systems, J. Am. Chem. Soc. 77, 307-12(1955).
7. Brookhaven National Laboratory Nuclear Engineering Department Progress Report, April 16 - November 15, 1955, BNL 380.

8. R.W. Fisher and G.R. Winders, High temperature loop for circulating molten metals, Paper No. 26, A.I. Ch.E. Annual Meeting, Nov. 29, 1955.

9. C. J. Raseman, H. Susskind, G. Farber, W.E. MCNulty, and F. J. Salzano, Engineering Experience at Brookhaven National Laboratory in Handling Fused Chloride Salts, BNL 627 (T-192), June 1960.

10. C. J. Raseman and J. Weisman, Liquid Metal Fuel Reactor Processing Loops, Part I, BNL 322 (T-55), June 1954.

11. F. J. Salzano and F.B. Hill, Unpublished work at BNL, 1958.

12. J. Forrest and H.L. Finston, The spectrochemical analysis of bismuth using a photoelectric spectrometer, Appl. Spectroscopy 14, 127-30 (1960).

13. J. Forrest, BNL, Private communication, 1960.

14. E.B. Sandell, Colorimetric Determination of Traces of Metals, Second Edition, Interscience, New York, 1950.

15. L. Newman, BNL, Private communication, 1960.

16. J.H. Yoe, F. Weill III, and K.A. Block, Anal. Chem. 25, 1200 (1953).

17. R.W. Stoenner, BNL, Private communication, 1960. 
APPENDIX A

Mill Test Reports of Metallic Materials Tested

(Composition in weight \%)

\begin{tabular}{|c|c|c|c|c|c|c|c|c|c|c|}
\hline & $\mathrm{Cr}$ & $\mathrm{Ni}$ & $\mathrm{Fe}$ & Mo & $\mathrm{P}$ & $\mathrm{C}$ & $\mathrm{Cu}$ &. $\mathrm{Si}$ & S & $\mathrm{Mn}$ \\
\hline Inor-8 ${ }^{a}$ & 6.99 & 70.50 & 4.85 & 15.82 & 0.009 & 0.02 & 0.03 & 0.32 & 0.014 & 0.34 \\
\hline Hastelloy $\mathrm{C}^{\mathrm{b}}$ & 15.63 & Balance & 6.57 & 15.43 & 0.012 & 0.05 & - & 0.48 & 0.006 & 0.48 \\
\hline Inconel & 15.76 & 75.91 & 7.34 & - & - & 0.04 & 0.17 & 0.18 & 0.007 & 0.23 \\
\hline S.S. 304 (ELC) & 18.37 & 10.51 & Balance & 0.01 & 0.02 & 0.03 & 0.12 & 0.47 & 0.09 & 1.17 \\
\hline S.S. 310 & 25.19 & 21.52 & $" 1$ & 0.12 & 0.022 & 0.038 & 0.20 & 0.28 & 0.004 & 1.73 \\
\hline S.S. 316 & 16.99 & 13.25 & $"$ & 2.32 & 0.022 & 0.05 & - & 0.68 & 0.015 & 1.86 \\
\hline S.S. $347^{c}$ & 17.49 & 11.4 & " & 0.23 & 0.019 & 0.051 & 0.19 & 0.54 & 0.007 & 1.71 \\
\hline S.S. 410 & 12.39 & 0.21 & $"$ & 0.08 & 0.021 & 0.13 & 0.14 & 0.37 & 0.012 & 0.70 \\
\hline S.S. 430 & 16.79 & 0.31 & $"$ & - & 0.02 & 0.072 & - & 0.18 & 0.01 & 0.35 \\
\hline S.S. 446 & 26.50 & 0.22 & $" 1$ & - & 0.014 & 0.10 & 0.176 & 0.72 & 0.006 & 0.58 \\
\hline 5 Croloy $^{\mathrm{d}}$ & 5.0 & - & $"$ & 0.5 & 0.02 & 0.1 & - & 0.5 & 0.02 & 0.45 \\
\hline 16-1 Croloy & 16.64 & 0.85 & " & 0.02 & 0.016 & 0.02 & 0.13 & 0.20 & 0.02 & 0.57 \\
\hline $21 / 4 \mathrm{Cr}-1 \mathrm{Mo}$ & 2.30 & - & " & 1.03 & 0.016 & 0.11 & - & 0.37 & 0.016 & 0.46 \\
\hline $1 \frac{1}{4} \mathrm{Cr}-1 / 2 \mathrm{Mo}$ & 1.10 & - & " & 0.54 & 0.017 & 0.11 & 0.05 & 0.55 & 0.011 & 0.39 \\
\hline $1020 \mathrm{Mild}^{\text {steel }}{ }^{\mathrm{d}}$ & - & - & 11 & - & $0.04^{\mathrm{m}}$ & 0.20 & - & - & $0.05^{\mathrm{m}}$ & - \\
\hline Gold $^{e}$ & - & - & - & - & - & - & - & - & - & - \\
\hline Molybdenum $^{\mathrm{d}}$ & - & $0.02^{\mathrm{m}}$ & 0.005 & 99.9 & 0.03 & - & - & - & - & - \\
\hline Tantalum $^{\mathrm{f}}$ & - & - & 0.03 & - & - & 0.03 & - & - & - & - \\
\hline Stellite-90 & 27 & - & Balance & - & - & 2.75 & - & $1^{\mathrm{m}}$ & - & $1^{\mathrm{m}}$ \\
\hline
\end{tabular}

${ }^{\mathrm{a} A l s o}$ contains Co, $0.51 ; \mathrm{W}, 0.35 ; \mathrm{B}, 0.04$.

${ }^{\mathrm{b}}$ Also contains $\mathrm{W}, 3.86 ; \mathrm{V}, 0.24$.

'Also contains $\mathrm{Cb}, 0.68$; Te, 0.049 .

${ }^{\mathrm{d}}$ Nominal composition.

${ }^{\mathrm{e}}$ Nominal composition: $\mathrm{Au}, 99.9+$; $\mathrm{Ag}, 0.02$; $\mathrm{Cu}, 0.002$.

${ }^{\mathrm{f}}$ Nominal composition: Ta, 99.9.

${ }^{\mathrm{g}}$ Also contains $3 \%$ trace elements consisting of $\mathrm{Mo}, \mathrm{Ni}$, and $\mathrm{Co}$.

maximum. 


\section{APPENDIX B}

\section{CHEMICAL ANALYSIS OF BI-U FUEL AND FUSED SALT SOLUTIONS}

The following methods were used to measure the concentrations of corrosion products $(\mathrm{Fe}, \mathrm{Cr}$, $\mathrm{Mn}, \mathrm{Ni}, \mathrm{Mo}$, and $\mathrm{Ta}$ ) and additives ( $\mathrm{U}$ and $\mathrm{Zr}$ ) in the $\mathrm{Bi}-\mathrm{U}$ fuel and fused salt solutions, of $\mathrm{Mg}$ in $\mathrm{Bi}$ $\mathrm{U}$ fuel solution, and of $\mathrm{Au}$ and $\mathrm{BiCl}_{3}$ (as $\mathrm{Bi}$ ) in the fused salt.

Procedures were developed at Brookhaven to analyze for $\mathrm{Fe}, \mathrm{Cr}, \mathrm{Mn}$, and $\mathrm{Ni}$ in both $\mathrm{Bi}^{12}$ and fused salt, ${ }^{13}$ for $\mathrm{Mg}$ and $\mathrm{Zr}$ in $\mathrm{Bi},{ }^{12}$ and for $\mathrm{Zr}$ in fused salt ${ }^{13}$ with the emission spectrograph. Solution techniques were used in all cases. The lower limits of detection are $10 \mathrm{ppm}$ for corrosion products, $10 \mathrm{ppm}$ for $\mathrm{Mg}$ in $\mathrm{Bi}, 50 \mathrm{ppm}$ for $\mathrm{Zr}$ in $\mathrm{Bi}$, and $20 \mathrm{ppm}$ for $\mathrm{Zr}$ in fused salt.

The concentration of Mo in the fused salt was determined by the spectrophotometric thiocyanate- $\mathrm{SnCl}_{2}$ method. ${ }^{14}$ The addition of copious quantities of $\mathrm{NH}_{4} \mathrm{Cl}$ permitted the method to be used also for the analysis of $\mathrm{Mo}$ in $\mathrm{Bi}-\mathrm{U}$ fuel solution. The lower limit of detection is 5 ppm.

The Ta concentration in both the fused salt and the $\mathrm{Bi}-\mathrm{U}$ fuel solutions was determined with the emission spectrograph, with $\mathrm{Nb}$ used as a carrier and also as an internal standard. ${ }^{15}$ In the analysis for $\mathrm{Ta}$ in $\mathrm{Bi}-\mathrm{U}$ fuel, the $\mathrm{Bi}$ had to be separated from the combined $\mathrm{Nb}-\mathrm{Bi}(\mathrm{OH})_{3}$ precipitate; this was accomplished by addition of $\mathrm{NH}_{4} \mathrm{Cl}$ and volatilization of the $\mathrm{BiCl}_{3}$ formed. The lower limit of detection is $10 \mathrm{ppm}$.

The Au concentration in the fused salt was measured by the $\mathrm{SnCl}_{2}$ method, ${ }^{14}$ in which a solution of colloidal $\mathrm{Au}$ is obtained and analyzed spectrophotometrically. The lower limit of detection is $0.1 \mathrm{ppm}$.

The concentration of $\mathrm{BiCl}_{3}$ (as $\mathrm{Bi}$ ) in the fused salt was determined by the spectrophotometric $\mathrm{BiI}_{3}$ method, ${ }^{14}$ which permits analysis down to $0.05 \%$.

$\mathrm{U}$ was determined in both $\mathrm{Bi}$ and fused salt by the spectrophotometric dibenzoylmethane method of Yoe et al., ${ }^{16}$ as modified by Stoenner of the Brookhaven Chemistry Department. ${ }^{17}$ The lower limit of detection is $10 \mathrm{ppm}$. 


\section{APPENDIX C}

\section{AXIAL TEMPERATURE PROFILE OF TILTING-FURNACE CAPSULE}

The axial temperature profile of a typical capsule was measured by means of thermocouples inserted into wells adjacent to the two skin thermocouples at either end of the capsule and in wells at 5 intermediate points. The hot and cold end temperatures were controlled as described in the main body of the report. The thermocouples from all 7 thermowells were connected through a selector switch to a Brown strip chart recorder. Figure 26 is a representation of the temperature levels and temperature fluctuations obtained at each point. It may be seen that the hottest part of the capsule was at a temperature of about $525^{\circ} \mathrm{C}-\operatorname{not} 500^{\circ} \mathrm{C}$ as desired - and this was not at the control point but at the midpoint of the capsule. The temperature difference between the hottest and coldest part of the capsule was therefore about $75^{\circ} \mathrm{C}$ rather than $50^{\circ} \mathrm{C}$; however, the temperature difference between the tab and the coldest point was $50^{\circ} \mathrm{C}$.

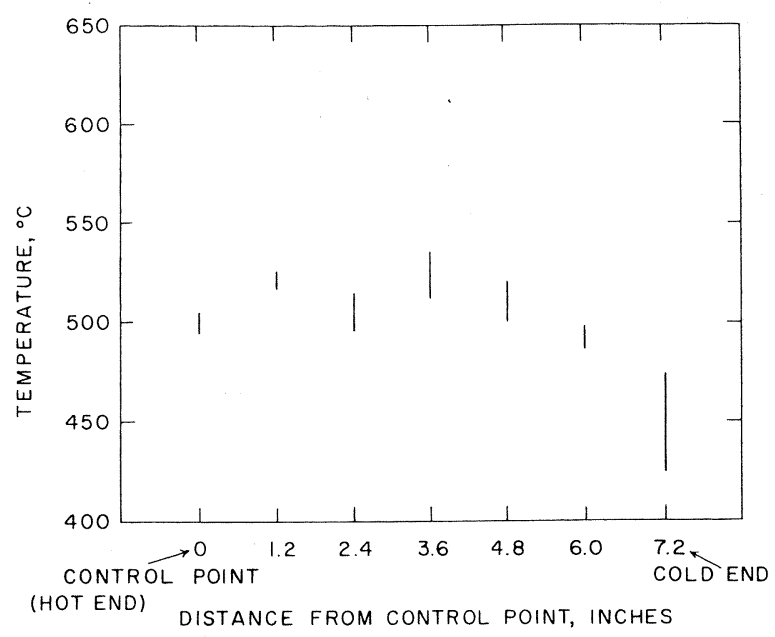

Figure 26. Axial temperature profile of a tilting-furnace capsule. Variation of the temperature at each point of measurement over a complete tilting cycle is indicated. 
APPENDIX D

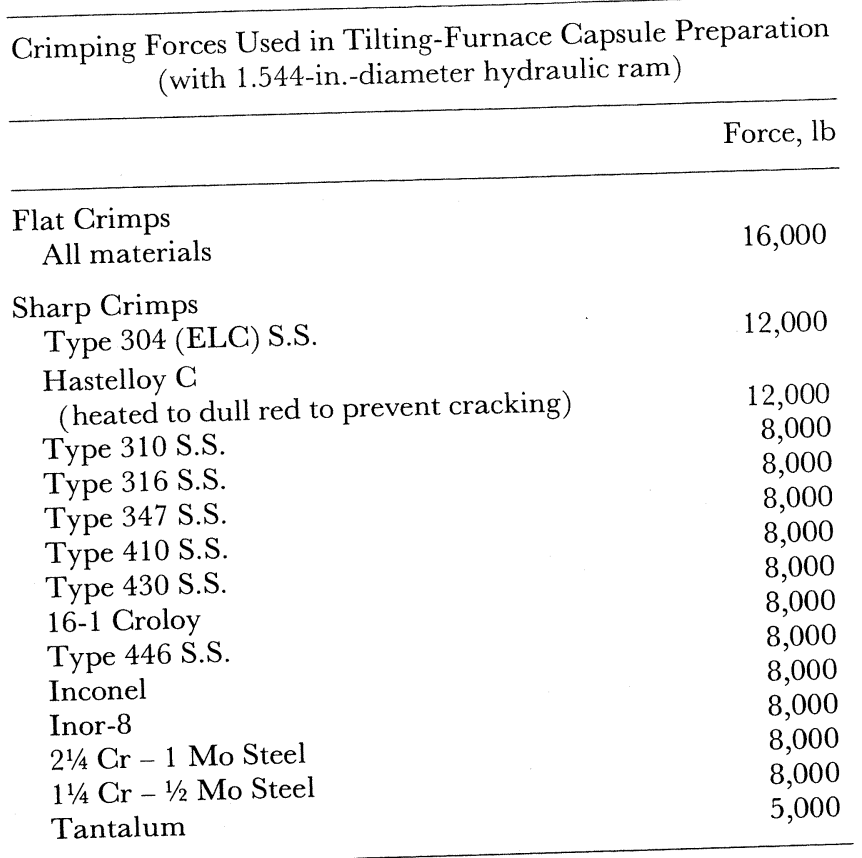


APPENDIX E

TEST DATA AND RESULTS FOR TILTING-FURNACE CAPSULE SCREENING TESTS

\begin{tabular}{|c|c|c|c|c|c|c|c|c|}
\hline \multicolumn{9}{|c|}{ Corrodent: $\mathrm{NaCl}-\mathrm{KCl}-\mathrm{MgCl}_{2}$ Eutectic } \\
\hline \multirow{2}{*}{$\begin{array}{l}\text { Material } \\
\text { Sample No. }\end{array}$} & \multicolumn{2}{|c|}{1020 Mild Steel } & \multicolumn{4}{|c|}{$2 \frac{1}{4} \mathrm{Cr}-1 \mathrm{Mo}$} & \multicolumn{2}{|c|}{304 (ELG) S.S. } \\
\hline & $\mathrm{T}-12^{\mathrm{a}}$ & $\mathrm{T}-13^{\mathrm{a}, \mathrm{b}}$ & $\mathrm{J}-12^{\mathrm{b}}$ & $J-13^{b}$ & $\mathrm{~J}-16^{\mathrm{b}, \mathrm{c}}$ & $\mathrm{J}-17^{\mathrm{b}, \mathrm{c}}$ & A-12 & A-13 \\
\hline Av. hot end $T,{ }^{\circ} \mathrm{C}$ & 500 & 500 & 502 & 502 & 500 & 500 & 501 & 501 \\
\hline Av. $\Delta T,{ }^{\circ} \mathrm{C}$ & 50 & 50 & 50 & 50 & 50 & 50 & 52 & 52 \\
\hline Outgassing $\mathcal{T},{ }^{\circ} \mathrm{C}$ & 550 & 550 & 550 & 550 & 550 & 550 & 550 & 550 \\
\hline Outgassing time, hr & 5 & 5 & 4 & 4 & 17 & 17 & 4 & 4 \\
\hline Length of test, hr & 1000 & 1000 & 1000 & 1000 & 2500 & 2500 & 1000 & 1000 \\
\hline Weight loss of tab, \% & 0.286 & +0.05 & +0.22 & +0.24 & +2.3 & +1.1 & 0.39 & 0.08 \\
\hline Weight loss of tab, $\mathrm{mg} / \mathrm{cm}^{2}$ & 2.9 & +0.49 & +1.34 & +1.46 & +12.3 & +6.0 & 2.27 & 0.49 \\
\hline \multicolumn{9}{|l|}{ Polished side of tab } \\
\hline Type of corrosion & None & None & $\mathrm{I} \& \mathrm{~T}^{*}$ & $\mathrm{I} \& \mathrm{~T}$ & None & None & $\mathrm{I}$ & I \\
\hline Max. penetration, mils & 0 & 0 & 0.38 & 0.30 & 0 & 0 & $<0.05$ & $<0.05$ \\
\hline \multicolumn{9}{|l|}{ Salt analysis, ppm } \\
\hline $\mathrm{Ni}$ & - & - & - & - & - & - & 24 & $<10$ \\
\hline $\mathrm{Cr}$ & - & - & 640 & 790 & 820 & 440 & 600 & 520 \\
\hline $\mathrm{Fe}$ & 130 & 107 & 63 & 265 & 330 & 590 & 163 & 18 \\
\hline $\mathrm{Mn}$ & 183 & 142 & 114 & 122 & 440 & 590 & 147 & 158 \\
\hline Material & \multicolumn{2}{|c|}{310 S.S. } & \multicolumn{2}{|c|}{316 S.S. } & \multicolumn{2}{|c|}{347 S.S. } & \multicolumn{2}{|c|}{410 S.S. } \\
\hline Sample No. & $\mathrm{B}-14^{\mathrm{d}}$ & $B-15^{d}$ & $\mathrm{C}-12$ & $\mathrm{C}-13^{\mathrm{d}}$ & $\mathrm{D}-12^{\mathrm{d}}$ & D- $15^{d}$ & $\mathrm{E}-12^{\mathrm{d}}$ & $\mathrm{E}-13^{\mathrm{e}}$ \\
\hline Av. hot end $T,{ }^{\circ} \mathrm{C}$ & 503 & 501 & 503 & 501 & 501 & 501 & 503 & 501 \\
\hline Av. $\Delta T,{ }^{\circ} \mathrm{C}$ & 52 & 51 & 52 & 51 & 51 & 51 & 52 & 51 \\
\hline Outgassing $\mathcal{T},{ }^{\circ} \mathrm{C}$ & 550 & 550 & 550 & 550 & 550 & 550 & 600 & 550 \\
\hline Outgassing time, $\mathrm{hr}$ & 8 & 4 & 4 & 4 & 4 & 4 & 4 & 4 \\
\hline Length of test, hr & 1000 & 1000 & 1000 & 1000 & 1000 & 1000 & 1000 & 1000 \\
\hline Weight loss of tab, \% & 0.10 & 0.10 & 0.10 & 0.13 & 0.25 & 0.10 & 0.12 & 0.16 \\
\hline Weight loss of tab, $\mathrm{mg} / \mathrm{cm}^{2}$ & 0.32 & 0.32 & 0.29 & 0.36 & 0.75 & 0.29 & 0.35 & 0.6 \\
\hline \multicolumn{9}{|l|}{ Polished side of tab } \\
\hline Type of corrosion & None & None & I & I & I\&T & $\mathrm{I} \& \mathrm{~T}$ & I & I \\
\hline Max. penetration, mils & 0 & 0 & $<0.05$ & $<0.05$ & 0.60 & 0.46 & 0.08 & 0.15 \\
\hline \multicolumn{9}{|l|}{ Salt analysis, ppm } \\
\hline $\mathrm{Ni}$ & $<10$ & $<10$ & $<10$ & 11 & $<10$ & $<10$ & 12 & $<10$ \\
\hline $\mathrm{Cr}$ & $>300$ & 61 & $>250$ & $>250$ & 570 & 173 & $>300$ & $>300$ \\
\hline $\mathrm{Fe}$ & 54 & 33 & 29 & 37 & 21 & 24 & 75 & 42 \\
\hline $\mathrm{Mn}$ & 105 & 56 & 127 & 88 & 141 & 75 & 70 & 85 \\
\hline \multicolumn{9}{|c|}{$\begin{array}{l}{ }^{*} \mathrm{I}=\text { intergranular; } \mathrm{T}=\text { transgranular. } \\
{ }^{\mathrm{a}} \text { Inside surface of capsule showed more corrosion than polished side of tab. } \\
{ }^{\mathrm{b}} \text { Metal deposited on tab. } \\
{ }^{\mathrm{c}} \text { Inside surface of capsule decarburized. } \\
{ }^{\mathrm{d}} \text { Light rusting at cold end of capsule, probably due to Fe deposition. } \\
\text { ePlug at cold end of capsule. }\end{array}$} \\
\hline
\end{tabular}




\begin{tabular}{|c|c|c|c|c|c|c|c|c|}
\hline \multirow{3}{*}{$\frac{\text { Material }}{\text { Sample No. }}$} & \multicolumn{7}{|c|}{ Corrodent: NaCl-KGl- $\mathrm{MgCl}_{2}$ Eutectic (continued) } & \\
\hline & \multicolumn{2}{|c|}{430 S.S. } & \multicolumn{2}{|c|}{ 16-1 Croloy } & \multicolumn{2}{|c|}{446 S.S. } & \multicolumn{2}{|c|}{ Inconel } \\
\hline & $\mathrm{N}-12$ & $\mathrm{~N}-13$ & M-12 & $M-13^{f}$ & $\mathrm{~F}-12^{\mathrm{e}}$ & $\mathrm{F}-13^{\mathrm{e}}$ & G-12 & G-13 \\
\hline Av. hot end $\mathcal{T},{ }^{\circ} \mathrm{C}$ & 501 & 501 & 501 & 501 & 501 & 501 & 503 & 501 \\
\hline Av. $\Delta \mathcal{T},{ }^{\circ} \mathrm{C}$ & 52 & 52 & 52 & 52 & 51 & 51 & 52 & 51 \\
\hline Outgassing $T,{ }^{\circ} \mathrm{C}$ & 550 & 550 & 550 & 550 & 600 & 550 & 550 & 550 \\
\hline Outgassing time, hr & 4 & 4 & 4 & 4 & 4 & 4 & 4 & 4 \\
\hline Length of test, hr & 1000 & 1000 & 1000 & 1000 & 1000 & 1000 & 1000 & 1000 \\
\hline Weight loss of tab, \% & 0.03 & 0.02 & +0.39 & +0.01 & +0.07 & 0.20 & 0.13 & 0.08 \\
\hline Weight loss of $\mathrm{tab}, \mathrm{mg} / \mathrm{cm}^{2}$ & 0.115 & 0.075 & +1.86 & +0.58 & +0.34 & 0.62 & 0.45 & 0.27 \\
\hline \multirow{2}{*}{\multicolumn{9}{|c|}{$\begin{array}{l}\text { Weight loss of } \mathrm{tab}, \mathrm{mg} / \mathrm{cm}^{2} \\
\text { Polished side of tab } \\
\text { Type of corrosion }\end{array}$}} \\
\hline & None & I & I & I & I & I & None & I \\
\hline & 0 & 0.2 & $<0.05$ & $<0.05$ & $<0.05$ & $<0.05$ & 0 & 0.4 \\
\hline \multicolumn{9}{|l|}{$\begin{array}{l}\text { Max. penetration, mils } \\
\text { Salt analysis, ppm }\end{array}$} \\
\hline $\mathrm{Ni}$ & 17 & 60 & - & - & - & - & $\begin{array}{r}26 \\
240\end{array}$ & $\begin{array}{r}25 \\
240\end{array}$ \\
\hline $\mathrm{Cr}$ & 80 & 70 & 153 & 350 & $>1000$ & $>1000$ & 240 & 240 \\
\hline $\mathrm{Fe}$ & 47 & 75 & 24 & 36 & 61 & 33 & 16 & 19 \\
\hline $\mathrm{Mn}$ & 19 & 20 & 88 & 97 & 143 & 48 & 19 & 19 \\
\hline Material & \multicolumn{2}{|c|}{ Inor 8} & \multicolumn{2}{|c|}{ Mo } & \multicolumn{4}{|c|}{$\mathrm{Ta}$} \\
\hline Sample No. & P-12 & $\mathrm{P}-13^{\mathrm{a}, \mathrm{e}}$ & $\mathrm{K}-12$ & $\mathrm{~K}-13$ & L-14 & L-15 & $\mathrm{L}-18^{\mathrm{a}}$ & $\mathrm{L}-19^{\mathrm{a}}$ \\
\hline Av. hot end $T,{ }^{\circ} \mathrm{C}$ & 505 & 505 & 505 & 505 & 504 & 504 & 502 & 502 \\
\hline Av. $\Delta T,{ }^{\circ} \mathrm{C}$ & 53 & 53 & 54 & 54 & 51 & 51 & 48 & 48 \\
\hline Outgassing $T,{ }^{\circ} \mathrm{C}$ & 550 & 550 & 550 & 550 & 550 & 550 & 550 & 550 \\
\hline Outgassing time, hr & 3.5 & 3.5 & 3 & 3 & 4 & 4 & 4.5 & 4.5 \\
\hline Length of test, hr & 1000 & 1000 & 1000 & 1000 & 1000 & 1000 & 1000 & 1000 \\
\hline Weight loss of tab, \% & 0.02 & 0.01 & 0.14 & $\dagger$ & 0.05 & 0.03 & 0.05 & 0 \\
\hline Weight loss of $\mathrm{tab}, \mathrm{mg} / \mathrm{cm}^{2}$ & $\dagger$ & $\dagger$ & 0.32 & $\dagger$ & 0.18 & 0.11 & 0.17 & 0 \\
\hline Polished side of tab & & & & & & & & \\
\hline Type of corrosion & $\mathrm{T}$ & None & None & None & I & I & None & None \\
\hline Max penetration, mils & 0.46 & 0 & 0 & 0 & 1.2 & $<0.05$ & 0 & 0 \\
\hline \multicolumn{9}{|l|}{$\begin{array}{l}\text { Max. penetration, mils } \\
\text { Salt analysis, ppm }\end{array}$} \\
\hline $\mathrm{Ni}$ & 17 & 60 & - & $<10$ & - & - & - & - \\
\hline $\mathrm{Cr}$ & 80 & 70 & - & 17 & - & - & - & - \\
\hline $\mathrm{Fe}$ & 47 & 75 & 14 & 113 & - & - & - & - \\
\hline $\mathrm{Mn}$ & 19 & 20 & - & - & - & - & - & - \\
\hline Mo & - & - & 600 & 600 & - & $\overline{5}$ & $\overline{160}$ & $\overline{150}$ \\
\hline $\mathrm{Ta}$ & - & - & - & - & 32 & 51 & 160 & 150 \\
\hline
\end{tabular}

$\dagger$ Not measured.

${ }^{\text {}}$ Possibility of air contamination during sealing. 


\begin{tabular}{|c|c|c|c|c|c|c|c|c|}
\hline \multicolumn{9}{|c|}{ Welded Tab Specimens; Corrodent: $\mathrm{NaCl}-\mathrm{KCl}-\mathrm{MgCl}_{2}$ Eutectic } \\
\hline \multirow{2}{*}{$\begin{array}{l}\text { Material } \\
\text { Sample No. }\end{array}$} & \multicolumn{2}{|c|}{$2^{1 / 4} \mathrm{Cr}-1 \mathrm{Mo}$} & \multicolumn{2}{|c|}{347 S.S. } & \multicolumn{2}{|c|}{446 S.S. } & \multicolumn{2}{|c|}{ Inconel } \\
\hline & $\mathrm{J}-22^{\mathrm{g}, \mathrm{h}}$ & $\mathrm{J}-23^{\mathrm{g}, \mathrm{h}}$ & $\mathrm{D}-20^{\mathrm{h}, \mathrm{i}}$ & $\mathrm{D}-21^{\mathrm{h}, \mathrm{i}}$ & $F-18^{\mathrm{h}, \mathrm{j}}$ & $\mathrm{F}-19^{\mathrm{h}, \mathrm{j}}$ & $\mathrm{G}-14^{\mathrm{h}, \mathrm{k}}$ & $\mathrm{G}-15^{\mathrm{h}, \mathrm{k}}$ \\
\hline Av. hot end $T,{ }^{\circ} \mathrm{C}$ & 503 & 503 & 503 & 503 & 501 & 501 & 501 & 501 \\
\hline Av. $\Delta T,{ }^{\circ} \mathrm{G}$ & 56 & 56 & 56 & 56 & 50 & 50 & 50 & 50 \\
\hline Outgassing $T,{ }^{\circ} \mathrm{C}$ & 500 & 500 & 500 & 500 & 500 & 500 & 500 & 500 \\
\hline Outgassing time, $\mathrm{hr}$ & 14 & 14 & 8 & 8 & 5 & 5 & 16 & 16 \\
\hline Length of test, hr & 2500 & 2500 & 2500 & 2500 & 2500 & 2500 & 2500 & 2500 \\
\hline Weight loss of tab, \% & +0.94 & +1.79 & 0.16 & 0.07 & +0.2 & 2.76 & 0 & +0.1 \\
\hline \multicolumn{9}{|l|}{ Weld } \\
\hline Type of corrosion & $\mathrm{I} \& \mathrm{~T}$ & $\mathrm{I} \& \mathrm{~T}$ & $\mathrm{~T}$ & None & $\mathrm{I} \& \mathrm{~T}$ & I & $\mathrm{T}$ & $\mathrm{T}$ \\
\hline Max. penetration, mils & $<0.05$ & $<0.05$ & 0.12 & 0 & 0.05 & 0.05 & 0.2 & 0.2 \\
\hline \multicolumn{9}{|l|}{ Polished side of tab } \\
\hline Type of corrosion & $\mathrm{T}$ & $\mathrm{T}$ & $\mathrm{T}$ & $\mathrm{T}$ & $\mathrm{T}$ & $\mathrm{T}$ & $\mathrm{T}$ & $\mathrm{T}$ \\
\hline Max. penetration, mils & $<0.05$ & $<0.05$ & 0.2 & 0.2 & 0.1 & $<0.05$ & 0.1 & 0.2 \\
\hline \multicolumn{9}{|l|}{ Salt analysis, ppm } \\
\hline $\mathrm{Ni}$ & $<10$ & $<10$ & $<10$ & $<10$ & $<10$ & $<10$ & $<10$ & $<10$ \\
\hline $\mathrm{Cr}$ & 391 & $>500$ & 465 & 405 & $>500$ & $>500$ & 350 & 285 \\
\hline $\mathrm{Fe}$ & 130 & 350 & 123 & 59 & 135 & 73 & 33 & 22 \\
\hline $\mathrm{Mn}$ & 173 & 400 & 145 & 123 & 94 & 77 & 12 & $<10$ \\
\hline
\end{tabular}

gTab weld was stress relieved at $725^{\circ} \mathrm{C}$ for $1 \mathrm{hr}$.

${ }^{\mathrm{h}}$ The inside surface of the capsule showed nominal atlack, similar to that indicated in the table for nonwelded tabs.

${ }^{i}$ Tab weld was stress relieved at $825^{\circ} \mathrm{C}$ for $1 / 2 \mathrm{hr}$.

j Tab weld was stress relieved at $750^{\circ} \mathrm{C}$ for $2 \mathrm{hr}$.

kTab weld was stress relieved at $915^{\circ} \mathrm{C}$ for $1 / 2 \mathrm{hr}$. 


\begin{tabular}{|c|c|c|c|c|c|c|c|c|}
\hline \multicolumn{9}{|c|}{ Corrodent: Bi-U Fuel (1000 ppm U, 350 ppm Zr, 350 ppm Mg) and Ternary Eutectic } \\
\hline \multirow{2}{*}{$\begin{array}{l}\text { Material } \\
\text { Sample No. }\end{array}$} & \multicolumn{2}{|c|}{1020 Mild Steel } & \multicolumn{4}{|c|}{$2^{1 / 4} \mathrm{Cr}-1 \mathrm{Mo}$} & \multicolumn{2}{|c|}{304 (ELG) S.S. } \\
\hline & $\mathrm{T}-10$ & $\mathrm{~T}-11$ & $J-10$ & $\mathrm{~J}-11$ & $J-14^{\mathrm{c}}$ & $J-15^{c}$ & A $-10^{1}$ & A- $11^{1}$ \\
\hline Av. hot end $T,{ }^{\circ} \mathrm{C}$ & 502 & 502 & 500 & 500 & 504 & 504 & 500 & 500 \\
\hline Av. $\Delta T,{ }^{\circ} \mathrm{C}$ & 51 & 51 & 54 & 54 & 51 & 51 & 50 & 50 \\
\hline Outgassing $\mathrm{T},{ }^{\circ} \mathrm{C}$ & 550 & 550 & 700 & 700 & 550 & 550 & 850 & 850 \\
\hline Outgassing time, hr & 5 & 5 & 3 & 3 & 17 & 17 & 4 & 4 \\
\hline Length of test, hr & 1000 & 1000 & 1000 & 1000 & 2500 & 2500 & 1000 & 1000 \\
\hline Weight loss of tab, \% & +0.048 & +0.037 & +0.1 & +0.04 & +0.049 & 0 & 0.21 & 0.22 \\
\hline Weight loss of $\mathrm{tab}, \mathrm{mg} / \mathrm{cm}^{2}$ & +0.41 & +0.36 & +0.65 & +0.23 & +0.33 & 0 & 1.16 & 1.07 \\
\hline \multicolumn{9}{|l|}{$\begin{array}{l}\text { Weight loss of tab, } \mathrm{mg} / \mathrm{cm}^{2} \\
\text { Polished side of tab }\end{array}$} \\
\hline Type of corrosion & None & None & None & I & None & None & I & $\mathrm{T}$ \\
\hline Wetting & Yes & No & No & No & Yes & Yes & Yes & Yes \\
\hline Max. penetration, mils & 0 & 0 & 0 & $<0.05$ & 0 & 0 & 1.4 & 2.0 \\
\hline \multicolumn{9}{|l|}{$\begin{array}{l}\text { Max. penetration, mils } \\
\text { Sandblasted side of tab }\end{array}$} \\
\hline Type of corrosion & None & None & None & I & None & None & $\mathrm{T}$ & $\mathrm{T}$ \\
\hline Wetting & Yes & No & No & No & Yes & Yes & Yes & Yes \\
\hline Max. penetration, mils & 0 & 0 & 0 & $<0.05$ & 0 & 0 & 1.1 & 0.80 \\
\hline \multicolumn{9}{|l|}{$\begin{array}{l}\text { Max. penetration, mis } \\
\text { Inside capsule surface }\end{array}$} \\
\hline Type of corrosion & None & None & None & None & None & None & $\dagger$ & $\dagger$ \\
\hline Wetting & No & No & No & No & No & No & Yes & Yes \\
\hline Max. penetration, mils & 0 & 0 & 0 & 0 & 0 & 0 & $\dagger$ & $\dagger$ \\
\hline \multicolumn{9}{|l|}{ Bismuth analysis, ppm } \\
\hline $\mathrm{U}$ & 579 & 157 & 481 & 271 & 546 & 563 & 161 & 247 \\
\hline $\mathrm{Zr}$ & 168 & 0 & 132 & $<50$ & 132 & 138 & 100 & 96 \\
\hline $\mathrm{Mg}$ & 17 & $<10$ & 88 & $<10$ & 55 & 63 & 58 & 11 \\
\hline $\mathrm{Fe}$ & $<10$ & $<10$ & 12 & 12 & 45 & 11 & $<10$ & 11 \\
\hline $\mathrm{Cr}$ & - & - & 10 & 40 & $<10$ & $<10$ & $<10$ & $<10$ \\
\hline $\mathrm{Ni}$ & - & - & 31 & 10 & - & - & 85 & 39 \\
\hline $\mathrm{Mn}$ & - & - & 18 & 18 & - & - & 31 & 34 \\
\hline Mo & - & - & $<5$ & $<5$ & $<10$ & $<10$ & $<5$ & $<5$ \\
\hline \multicolumn{9}{|l|}{$\begin{array}{l}\text { Mo } \\
\text { Salt analysis, ppm }\end{array}$} \\
\hline $\mathrm{U}$ & 568 & 295 & 107 & 115 & 127 & 430 & 5 & 8 \\
\hline $\mathrm{Zr}$ & 31 & 36 & $<20$ & $<20$ & 30 & 17 & $<20$ & $<20$ \\
\hline $\mathrm{Fe}$ & 224 & 730 & 49 & 93 & 330 & 820 & 25 & 62 \\
\hline $\mathrm{Mn}$ & - & 24 & 0 & $<10$ & 0 & 33 & $<10$ & 18 \\
\hline $\mathrm{Cr}$ & - & - & 0 & 0 & 0 & 0 & $<10$ & 18 \\
\hline $\mathrm{Ni}$ & - & - & 0 & $<10$ & - & - & 0 & 0 \\
\hline Mo & - & - & - & - & $<10$ & $<10$ & - & - \\
\hline Approx. wt. of magnetic cold p & lug, g 0 & 0 & 0 & 0 & 0 & 0 & 0.1 & 0.1 \\
\hline
\end{tabular}

${ }^{1}$ Corrosion was found in longitudinal weld of capsule. 


\begin{tabular}{|c|c|c|c|c|c|c|c|c|}
\hline \multicolumn{9}{|c|}{ Corrodent: Bi-U (1000 ppm U, 350 ppm Zr, 350 ppm Mg) and Ternary Eutectic (continued) } \\
\hline \multirow{2}{*}{$\begin{array}{l}\text { Material } \\
\text { Sample No. }\end{array}$} & \multicolumn{2}{|c|}{310 S.S. } & \multicolumn{2}{|c|}{316 S.S. } & \multicolumn{4}{|c|}{347 S.S. } \\
\hline & B-12 & B-13 & $\mathrm{C}-10^{\mathrm{m}}$ & $\mathrm{C}-11^{\mathrm{m}}$ & D-10 & D-11 & $D-13^{\mathrm{n}}$ & D- $14^{\mathrm{n}}$ \\
\hline Av. hot end $T,{ }^{\circ} \mathrm{C}$ & 500 & 500 & 500 & 500 & 500 & 503 & 500 & 500 \\
\hline Av. $\Delta T,{ }^{\circ} \mathrm{C}$ & 53 & 53 & 52 & 52 & 50 & 48 & 52 & 52 \\
\hline Outgassing $T,{ }^{\circ} \mathrm{C}$ & 850 & 850 & 850 & 850 & 900 & 900 & 825 & 825 \\
\hline Outgassing time, $\mathrm{hr}$ & 3 & 3 & 6 & 6 & 4 & 3.5 & 4 & \\
\hline Length of test, hr & 1000 & 1000 & 1000 & 1000 & 1000 & 1000 & 1000 & 1000 \\
\hline Weight loss of tab, \% & 7.35 & 0.36 & 0.1 & 0.46 & $\dagger$ & $\dagger$ & 0.15 & 0.41 \\
\hline Weight loss of tab, $\mathrm{mg} / \mathrm{cm}^{2}$ & 22.3 & 1.07 & 0.28 & 1.34 & $\dagger$ & $\dagger$ & 0.43 & 1.2 \\
\hline \multicolumn{9}{|l|}{ Polished side of tab } \\
\hline Type of corrosion & $\mathrm{I} \& \mathrm{~T}$ & $\mathrm{I} \& \mathrm{~T}$ & $\mathrm{I}$ & I & I & $\mathrm{I}$ & I & \\
\hline Wetting & Yes & No & No & Yes & Yes & Yes & No & Yes \\
\hline Max. penetration, mils & 1.26 & 0.2 & $<0.05$ & 1.3 & 0.5 & 1.7 & $<0.05$ & 0.8 \\
\hline \multicolumn{9}{|l|}{ Sandblasted side of tab } \\
\hline Type of corrosion & $\mathrm{I}$ & I & I & I & I & I & I & \\
\hline Wetting & Yes & Yes & Yes & Yes & Yes & Yes & Yes & Yes \\
\hline Max. penetration, mils & 0.5 & 0.8 & 0.8 & 0.3 & 0.5 & 0.3 & 0.4 & 1.0 \\
\hline \multicolumn{9}{|l|}{ Inside capsule surface } \\
\hline Type of corrosion & I & I & I & I & I & I & I & I \\
\hline Wetting & Yes & Yes & Yes & Yes & Yes & Yes & Yes & Yes \\
\hline Max. penetration, mils & 1.1 & 0.3 & 0.95 & 0.8 & 0.6 & 0.3 & 0.1 & 1.0 \\
\hline \multicolumn{9}{|l|}{ Bismuth analysis, ppm } \\
\hline $\mathrm{U}$ & 18 & 190 & 257 & 271 & 672 & 743 & 269 & 348 \\
\hline $\mathrm{Zr}$ & $<50$ & $<50$ & 84 & 117 & 265 & 230 & 127 & 233 \\
\hline $\mathrm{Mg}$ & 208 & 322 & 138 & $<50$ & 155 & 70 & 215 & 207 \\
\hline $\mathrm{Fe}^{\circ}$ & 11 & 22 & $<10$ & $<10$ & $<10$ & $<10$ & 12 & $<10$ \\
\hline $\mathrm{Cr}$ & 19 & 27 & 10 & 10 & $<10$ & $<10$ & 10 & $<10$ \\
\hline $\mathrm{Ni}$ & 2900 & 1800 & 110 & 190 & 190 & 170 & 32 & 86 \\
\hline $\mathrm{Mn}$ & 110 & 110 & 39 & 59 & 41 & 69 & 28 & 34 \\
\hline Mo & $<5$ & $<10$ & - & - & - & - & - & - \\
\hline \multicolumn{9}{|l|}{ Salt analysis, ppm } \\
\hline $\mathrm{U}$ & 8 & 25 & 89 & 126 & Lost & 2 & 16 & 50 \\
\hline $\mathrm{Zr}$ & $<20$ & $<20$ & $<20$ & $<20$ & $"$ & 25 & $<20$ & 20 \\
\hline $\mathrm{Fe}$ & 12 & 17 & 34 & 43 & $"$ & 65 & 22 & 27 \\
\hline Mn & 20 & $<10$ & $<10$ & 11 & $"$ & $<10$ & $<10$ & $<10$ \\
\hline $\mathrm{Cr}$ & $<10$ & $<10$ & $<10$ & $<10$ & $"$ & $<30$ & $<10$ & $<10$ \\
\hline $\mathrm{Ni}$ & $<10$ & $<10$ & $<10$ & - & $" 1$ & $<25$ & $<10$ & $<10$ \\
\hline Approx. wt. of magnetic cold & g 1.0 & 0.1 & 0 & 0 & 0 & 0 & 0.1 & 0.1 \\
\hline
\end{tabular}

${ }^{\mathrm{m}}$ Capsule was sectioned below the salt-Bi interface. No salt was observed at the $\mathrm{Bi}$ - metal wall interface.

${ }^{n}$ The capsule and one side of the tab were electropolished. The corrosion data for the electropolished side of the tab are listed under the head "Sandblasted side of tab." 


\begin{tabular}{|c|c|c|c|c|c|c|c|c|}
\hline \multicolumn{9}{|c|}{ Corrodent: Bi-U (1000 ppm U, 350 ppm Zr, 350 ppm Mg) and Ternary Eutectic (continued) } \\
\hline \multirow{2}{*}{$\frac{\text { Material }}{\text { Sample No. }}$} & \multicolumn{2}{|c|}{410 S.S. } & \multicolumn{2}{|c|}{430 S.S. } & \multicolumn{2}{|c|}{ 16-1 Croloy } & \multicolumn{2}{|c|}{446 S.S. } \\
\hline & $\mathrm{E}-10$ & E-11 & $\mathrm{N}-10$ & $\mathrm{~N}-11$ & $\mathrm{M}-10^{\circ}$ & $M-11$ & F-10 & F-11 \\
\hline Av. hot end $T,{ }^{\circ} \mathrm{C}$ & 504 & 503 & 504 & 504 & 501 & 501 & 504 & 503 \\
\hline Av. $\Delta T,{ }^{\circ} \mathrm{C}$ & 50 & 48 & 52 & 52 & 52 & 52 & 50 & 48 \\
\hline Outgassing $T,{ }^{\circ} \mathrm{C}$ & 900 & 900 & 550 & 550 & 550 & 550 & 850 & 850 \\
\hline Outgassing time, $\mathrm{hr}$ & 4 & 4 & 4 & 4 & 4 & 4 & 10 & 3.5 \\
\hline Length of test, hr & 1000 & 1000 & 1000 & 1000 & 1000 & 1000 & 1000 & 1000 \\
\hline Weight loss of tab, \% & 1.69 & 2.85 & $\dagger$ & $\dagger$ & 1.5 & 0.76 & $\dagger$ & 0.11 \\
\hline Weight loss of tab, $\mathrm{mg} / \mathrm{cm}^{2}$ & 4.85 & 8.2 & $\dagger$ & $\dagger$ & 6.0 & 3.07 & $\dagger$ & 0.35 \\
\hline \multicolumn{9}{|l|}{ Polished side of $\mathrm{tab}$} \\
\hline Type of corrosion & I & I & I & I & $\mathrm{I}$ & I & None & None \\
\hline Wetting & Yes & Yes & Yes & Yes & Yes & Yes & No & No \\
\hline Max. penetration, mils & 0.8 & 0.6 & 0.3 & 0.9 & 0.5 & 0.5 & 0 & 0 \\
\hline \multicolumn{9}{|l|}{ Sandblasted side of tab } \\
\hline Type of corrosion & I & I & I & I & $\mathrm{I}$ & I & I & I \\
\hline Wetting & Yes & Yes & Yes & Yes & No & No & No & $\mathrm{No}$ \\
\hline Max. penetration, mils & 1.1 & 0.8 & 0.4 & 0.4 & 0.4 & 0.2 & 0.1 & 0.2 \\
\hline \multicolumn{9}{|l|}{ Inside capsule surface } \\
\hline Type of corrosion & I & None & I & I & I & I & $\dagger$ & I \\
\hline Wetting & Yes & No & Yes & Yes & Yes & Yes & No & No \\
\hline Max. penetration, mils & 0.31 & 0 & 0.2 & 0.3 & 0.4 & 0.8 & $\dagger$ & 0.1 \\
\hline \multicolumn{9}{|l|}{ Bismuth analysis, ppm } \\
\hline $\mathrm{U}$ & 387 & 438 & 419 & 519 & 325 & 300 & 672 & 532 \\
\hline $\mathrm{Zr}$ & $<50$ & $<50$ & 138 & 50 & 87 & 62 & 171 & 200 \\
\hline $\mathrm{Mg}$ & $<50$ & 64 & 171 & 207 & 35 & 220 & 101 & 123 \\
\hline $\mathrm{Fe}$ & $<10$ & 10 & 9 & 15 & 13 & 9 & $<10$ & $<10$ \\
\hline $\mathrm{Cr}$ & $<10$ & $<10$ & 16 & 17 & 16 & 13 & 16 & $<10$ \\
\hline $\mathrm{Ni}$ & 25 & 26 & 18 & 13 & 25 & 21 & 20 & $<10$ \\
\hline $\mathrm{Mn}$ & 84 & 38 & 19 & 16 & 39 & 34 & 12 & 40 \\
\hline \multicolumn{9}{|l|}{ Salt analysis, ppm } \\
\hline $\mathrm{U}$ & - & - & 192 & 228 & 88 & 231 & 4 & 18 \\
\hline $\mathrm{Zr}$ & $<20$ & $<20$ & $<20$ & $<20$ & $<20$ & $<20$ & $<10$ & 29 \\
\hline $\mathrm{Fe}$ & 80 & 24 & 67 & 51 & 34 & 35 & 30 & 290 \\
\hline $\mathrm{Mn}$ & 19 & $<10$ & 0 & 0 & 0 & 0 & $<10$ & 19 \\
\hline $\mathrm{Cr}$ & $<30$ & $<20$ & $<10$ & $<10$ & 12 & $<10$ & $<30$ & 115 \\
\hline $\mathrm{Ni}$ & $<25$ & $<25$ & 0 & 0 & 0 & 0 & $<25$ & $<25$ \\
\hline Approx. wt. of magnetic cold plug & g 3 & 1 & 0.75 & 0.3 & 0.5 & 0.5 & 0 & 0.1 \\
\hline
\end{tabular}

${ }^{\circ}$ Cold end of capsule was slightly oxidized before sealing. 
Corrodent: Bi-U Fuel (1000 ppm U, 350 ppm Zr, 350 ppm Mg) and Ternary Eutectic (continued)

\begin{tabular}{|c|c|c|c|c|c|c|c|c|c|c|}
\hline \multirow{2}{*}{$\frac{\text { Material }}{\text { Sample No. }}$} & \multicolumn{2}{|c|}{ Inconel } & \multicolumn{2}{|c|}{ Hastelloy C } & \multicolumn{2}{|c|}{ Inor 8} & \multicolumn{2}{|c|}{ Mo } & \multicolumn{2}{|c|}{$\mathrm{Ta}$} \\
\hline & G-10 & G-11 & $\mathrm{H}-10^{\mathrm{q}}$ & $\mathrm{H}-11^{\mathrm{q}}$ & $\mathrm{P}-10^{\mathrm{r}}$ & $\mathrm{P}-11^{\mathrm{r}}$ & $\mathrm{K}-10$ & $\mathrm{~K}-11$ & $\mathrm{~L}-12$ & L-13 \\
\hline Av. hot end $T,{ }^{\circ} \mathrm{C}$ & 504 & 503 & 503 & 503 & 504 & 504 & 505 & 505 & 501 & 501 \\
\hline Av. $\Delta T,{ }^{\circ} \mathrm{C}$ & 50 & 48 & 53 & 53 & 52 & 52 & 51 & 51 & 49 & 49 \\
\hline Outgassing $\mathcal{T},{ }^{\circ} \mathrm{C}$ & 850 & 850 & 850 & 850 & 550 & 550 & 550 & 550 & 850 & 850 \\
\hline Outgassing time, $\mathrm{hr}$ & 3.5 & 3.5 & 6 & 6 & 4 & 4 & 3 & 3 & 4 & 4 \\
\hline Length of test, hr & 1000 & 1000 & 1000 & 1000 & 1000 & 1000 & 1000 & 1000 & 1000 & 1000 \\
\hline Weight loss of tab, \% & 17.0 & $\dagger$ & 4.3 & 3.2 & 24.0 & 30.0 & +0.02 & $\dagger$ & 0.43 & 0.10 \\
\hline Weight loss of tab, $\mathrm{mg} / \mathrm{cm}^{2}$ & 60 & $\dagger$ & 14.7 & 22.2 & 107 & 121 & +0.05 & $\dagger$ & 1.51 & 0.38 \\
\hline \multicolumn{11}{|l|}{ Polished side of tab } \\
\hline Type of corrosion & $\mathrm{I} \& \mathrm{~T}$ & $\mathrm{I} \& \mathrm{~T}$ & $\mathrm{I} \& \mathrm{~T}$ & $I \& T$ & $\mathrm{I} \& \mathrm{~T}$ & $\mathrm{I} \& \mathrm{~T}$ & None & None & $\mathrm{T}$ & $\mathrm{T}$ \\
\hline Wetting & Yes & Yes & Yes & Yes & Yes & Yes & No & No & Yes & Yes \\
\hline Max. penetration, mils & $\mathrm{p}$ & $\mathrm{p}$ & 3.0 & 4.25 & $\mathrm{p}$ & $\mathrm{p}$ & 0 & 0 & 0.85 & 0.1 \\
\hline \multicolumn{11}{|l|}{$\begin{array}{l}\text { Sandblasted side of tab } \\
\text { Type of corrosion }\end{array}$} \\
\hline Type of corrosion & I & I & I & I & $\mathrm{I} \& \mathrm{~T}$ & $\mathrm{I} \& \mathrm{~T}$ & None & None & I & I \\
\hline Wetting & Yes & Yes & Yes & Yes & Yes & Yes & No & No & Yes & Yes \\
\hline Max. penetration, mils & 1.1 & 0.8 & 1.8 & 1.7 & $\mathrm{p}$ & $\mathrm{p}$ & 0 & 0 & 0.3 & 1.6 \\
\hline \multicolumn{11}{|l|}{ Inside capsule surface } \\
\hline Type of corrosion & I & None & I & I & $\mathrm{I} \& \mathrm{~T}$ & $I \& T$ & None & None & I & I \\
\hline Wetting & Yes & No & Yes & Yes & Yes & Yes & No & No & Yes & Yes \\
\hline Max. penetration, mils & 0.3 & 0 & 0.3 & 0.2 & $\mathrm{p}$ & $\mathrm{p}$ & 0 & 0 & 0.4 & 0.4 \\
\hline \multicolumn{11}{|l|}{$\begin{array}{l}\text { Bismuch analysis, ppm } \\
\text { U }\end{array}$} \\
\hline $\mathrm{U}$ & 61 & 55 & 18 & 41 & 6 & 18 & 570 & 185 & Lost & 1.4 \\
\hline $\mathrm{Zr}$ & 50 & - & $<50$ & $<50$ & $<30$ & $<30$ & 128 & 142 & 141 & $<30$ \\
\hline $\mathrm{Mg}$ & 386 & 354 & 126 & 10 & 397 & 569 & 92 & 192 & 32 & $<10$ \\
\hline $\mathrm{Fe}$ & $<100$ & 400 & 18 & 9 & 28 & 13 & 14 & 57 & - & - \\
\hline $\mathrm{Cr}$ & $<100$ & $<100$ & 15 & 15 & 10 & 32 & - & - & - & - \\
\hline $\mathrm{Ni}$ & $1.6 \%$ & $1.7 \%$ & 4100 & 2800 & 16 & $>1000$ & - & - & - & - \\
\hline $\mathrm{Mn}$ & 90 & 90 & 30 & 40 & 0 & $>250$ & - & - & - & - \\
\hline Mo & - & - & 35 & 7 & - & - & 0 & 0 & - & - \\
\hline $\mathrm{Ta}$ & - & - & - & - & - & - & - & - & Lost & 29 \\
\hline \multicolumn{11}{|l|}{$\begin{array}{l}\text { Salt analysis, ppm } \\
\text { U }\end{array}$} \\
\hline U & 55 & 0.3 & 15 & 8 & 7 & 2 & 2 & 0.3 & 144 & 3076 \\
\hline $\mathrm{Zr}$ & $<20$ & 52 & 20 & $<20$ & $<20$ & $<20$ & $<20$ & $<10$ & 17 & 123 \\
\hline $\mathrm{Fe}$ & 49 & 46 & 16 & 18 & $<10$ & 0 & 0 & $<10$ & - & - \\
\hline $\mathrm{Mn}$ & $<10$ & $<10$ & 0 & $<10$ & 95 & 0 & 0 & 0 & - & - \\
\hline $\mathrm{Cr}$ & $<30$ & $<30$ & $<10$ & $<10$ & $<10$ & $<10$ & 0 & 0 & - & - \\
\hline $\mathrm{Ni}$ & 55 & 38 & $<10$ & $<10$ & 385 & 10 & 0 & 0 & - & - \\
\hline Mo & - & - & - & - & - & - & $<100$ & $<100$ & - & - \\
\hline $\mathrm{Ta}$ & - & - & - & - & - & - & - & - & 29 & 57 \\
\hline Approx. wt. of magnetic co & 12 & 12 & 0.5 & 0.5 & $\dagger$ & $\dagger$ & 0 & 0 & 0 & 0 \\
\hline
\end{tabular}

${ }^{p}$ Corrosion was so extensive that it could not be measured accurately.

${ }^{\mathrm{q}}$ Nonmagnetic cold plug was found.

${ }^{r}$ There was a cold plug in the capsule, but no estimate of its weight was made. 


\begin{tabular}{|c|c|c|c|c|c|c|}
\hline \multicolumn{7}{|c|}{ Corrodent: $\mathrm{NaCl}-\mathrm{KCl}-\mathrm{MgCl}_{2}$ Eutectic Plus $4.76 \% \mathrm{BiCl}_{3}$} \\
\hline \multirow{2}{*}{$\frac{\text { Material }}{\text { Sample No. }}$} & \multicolumn{2}{|c|}{ Mo } & \multicolumn{2}{|c|}{$\mathrm{Ta}$} & \multicolumn{2}{|c|}{ Gold } \\
\hline & $\mathrm{K}-16^{\mathrm{s}, \mathrm{t}}$ & $\mathrm{K}-17^{\mathrm{s}, \mathrm{t}, \mathrm{u}}$ & $\mathrm{L}-22^{\mathrm{s}, \mathrm{t}, \mathrm{u}}$ & $\mathrm{L}-23^{\mathrm{s}, \mathrm{t}, \mathrm{u}}$ & $\mathrm{Au}-1^{\mathrm{v}}$ & $\mathrm{Au}-2^{\mathrm{v}, \mathrm{w}}$ \\
\hline Av. hot end $T,{ }^{\circ} \mathrm{C}$ & 503 & 503 & 503 & 503 & 503 & 503 \\
\hline Av. $\Delta T,{ }^{\circ} \mathrm{C}$ & 50 & 50 & 52 & 52 & 55 & 55 \\
\hline Outgassing $T,{ }^{\circ} \mathrm{C}$ & 550 & 550 & 550 & 550 & - & - \\
\hline Outgassing time, hr & 4 & 4 & 4.5 & 4.5 & - & - \\
\hline Length of test, hr & 600 & 600 & 1600 & 1600 & 1000 & 1000 \\
\hline Weight loss of tab, \% & $\dagger$ & $\dagger$ & 2.5 & 2.2 & 0.131 & 0.116 \\
\hline Weight loss of tab, $\mathrm{mg} / \mathrm{cm}^{2}$ & $\dagger$ & $\dagger$ & 8.7 & 7.8 & 0.33 & 0.3 \\
\hline \multicolumn{7}{|l|}{ Polished side of $\mathrm{tab}$} \\
\hline Type of corrosion & Pitting & Pitting & Pitting & Pitting & None & 1 \\
\hline Max. penetration, mils & 0.1 & 0.2 & 0.1 & 0.4 & 0 & 0.6 \\
\hline \multicolumn{7}{|l|}{ Salt analysis, ppm } \\
\hline Mo & Lost & Lost & - & - & - & - \\
\hline $\mathrm{Ta}$ & - & - & Lost & 130 & - & - \\
\hline $\mathrm{Au}$ & - & - & - & - & 15 & 15 \\
\hline $\mathrm{BiCl}_{3}$ & $<0.05 \%$ & $<0.05 \%$ & Lost & $<0.05 \%$ & $4.54 \%$ & $5.3 \%$ \\
\hline $\begin{array}{l}{ }^{\mathrm{s}} \text { Deposit of metallic Bi fo } \\
{ }^{\mathrm{t}} \text { Run was terminated wh } \\
\text { uInside capsule surface s } \\
{ }^{\mathrm{v}} \text { This was a glass capsule } \\
{ }^{\mathrm{w}} \text { The corrosion was foun }\end{array}$ & $\begin{array}{l}\text { ab and insi } \\
\text { sealing cor } \\
\text { tting and/ } \\
\text { ong Au tak } \\
\text { hot end of }\end{array}$ & $\begin{array}{l}\text { surface of } \\
\text { ner was ac } \\
\text { ntergranul } \\
\text { nning its l } \\
\text { long tab; }\end{array}$ & $\begin{array}{l}\text { le. } \\
\text { tally broke } \\
\text { rosion. } \\
\text { was found }\end{array}$ & he cold er & & \\
\hline
\end{tabular}


Corrodent: Bi-U Fuel/Ternary Eutectic Plus $4.76 \% \mathrm{BiCl}_{3}$

\begin{tabular}{|c|c|c|c|}
\hline \multirow{2}{*}{$\begin{array}{l}\text { Material } \\
\text { Sample No. }\end{array}$} & \multicolumn{2}{|c|}{ Mo } & \multirow{2}{*}{$\frac{\mathrm{Ta}}{\mathrm{L}-20^{\mathrm{x}, \mathrm{y}}}$} \\
\hline & $\mathrm{K}-14$ & $\mathrm{~K}-15$ & \\
\hline Av. hot end $T,{ }^{\circ} \mathrm{C}$ & 502 & 502 & 502 \\
\hline Av. $\Delta T,{ }^{\circ} \mathrm{C}$ & 49 & 49 & 50 \\
\hline Outgassing $T,{ }^{\circ} \mathrm{C}$ & 550 & 550 & 550 \\
\hline Outgassing time, $\mathrm{hr}$ & 4 & 4 & 4.5 \\
\hline Length of test, hr & 2500 & 2500 & 2500 \\
\hline Weight loss of tab, \% & 0.03 & 0.14 & 0.6 \\
\hline Weight loss of $\mathrm{tab}, \mathrm{mg} / \mathrm{cm}^{2}$ & 0.074 & 0.58 & 2.3 \\
\hline \multicolumn{4}{|l|}{ Polished side of tab } \\
\hline Type of corrosion & $\mathrm{T}$ & $\mathrm{T}$ & $\mathrm{T}$ \\
\hline Max. penetration, mils & 0.8 & 0.2 & 0.5 \\
\hline \multicolumn{4}{|l|}{ Bismuth analysis, ppm } \\
\hline $\mathrm{U}$ & 0 & 0 & 0 \\
\hline $\mathrm{Zr}$ & $<50$ & $<50$ & $<50$ \\
\hline $\mathrm{Mg}$ & $<50$ & $<40$ & $<40$ \\
\hline Mo & $<10$ & $<10$ & - \\
\hline $\mathrm{Ta}$ & - & - & 15 \\
\hline \multicolumn{4}{|l|}{ Salt analysis, ppm } \\
\hline $\mathrm{U}$ & 3540 & 3110 & 4150 \\
\hline $\mathrm{Zr}$ & 1020 & 1050 & - \\
\hline Mo & 1250 & 1420 & - \\
\hline $\mathrm{Ta}$ & - & - & 390 \\
\hline $\mathrm{BiCl}_{3}$ & $0.235 \%$ & $0.375 \%$ & $0.15 \%$ \\
\hline
\end{tabular}

${ }^{x}$ L-21, the duplicate of L-20, developed a crack in the glass enevelope and corroded because of air leakage. No results were obtained.

${ }^{y}$ The hot end of the inside capsule surface was corroded transgranularly and intergranularly. The maximum depth of penetration was $1 \mathrm{mil}$. 


\section{APPENDIX F}

\section{RESULTS OF THERMAL CONVECTION AND FORCED CONVECTION LOOP CORROSION PRODUCT ANALYSES}

\begin{tabular}{crrrcc}
\hline Sample & Time, hr & Fe, ppm & Cr, ppm & Mn, ppm & Ni, ppm \\
\hline \multicolumn{5}{c}{ Corrodent: LiCl-KCl Eutectic; Loop L-1 } \\
\hline 1 & 841.5 & 171 & 62 & 63 & ND \\
2 & 865.5 & 49 & 83 & 37 & ND \\
3 & 1343.5 & 69 & 42 & 68 & ND \\
4 & 1511.5 & 99 & 93 & 62 & ND \\
5 & 1871.5 & 146 & 113 & 62 & ND \\
\hline
\end{tabular}

Corrodent: LiCl-KCl Eutectic; Loop L-3

\begin{tabular}{|c|c|c|c|c|c|}
\hline 200 & 213 & $0.11 \%$ & 21 & 95 & ND \\
\hline \multicolumn{6}{|c|}{ Corrodent: NaCl-KCl-MgCl${ }_{2}$ Eutectic; Loop L-5 } \\
\hline 0 & 0 & $<10$ & 12 & ND & $<10$ \\
\hline 1 & 19 & 29 & 68 & $<10$ & ND \\
\hline 2 & 139.2 & 740 & 97 & 10 & $<10$ \\
\hline 3 & 186.5 & 23 & 61 & $<10$ & ND \\
\hline 4 & 305.5 & 101 & 106 & 12 & ND \\
\hline 5 & 358 & 80 & 84 & 10 & ND \\
\hline 6 & 473 & 125 & 104 & 13 & ND \\
\hline 7 & 528.3 & 885 & 108 & 15 & ND \\
\hline $8 \mathrm{~A}$ & 605 & 96 & 119 & 14 & ND \\
\hline $8 B$ & 689.7 & 103 & 131 & 13 & ND \\
\hline 9 & 785.9 & 107 & 123 & 22 & ND \\
\hline 10 & 857.2 & 206 & 150 & 14 & ND \\
\hline 11 & 978 & 181 & 172 & 20 & ND \\
\hline 12 & 1024.7 & 220 & 197 & 17 & ND \\
\hline 13 & 1143.7 & 315 & 209 & 14 & ND \\
\hline 14 & 1192 & 258 & 210 & 25 & ND \\
\hline 15 & 1316.3 & 315 & 213 & 30 & ND \\
\hline 16 & 1360.1 & 300 & 265 & 22 & ND \\
\hline 17 & 1479.2 & 305 & 245 & 28 & ND \\
\hline 18 & 1527.3 & 250 & 238 & 24 & ND \\
\hline 19 & 1702.1 & 240 & 265 & 26 & ND \\
\hline 20 & 1960.2 & 178 & 276 & 28 & ND \\
\hline 21 & 2032.4 & 235 & 328 & 27 & ND \\
\hline 22 & 2203.0 & 224 & 393 & 25 & ND \\
\hline \multicolumn{6}{|c|}{ Corrodent: $\mathrm{NaCl}-\mathrm{KCl}-\mathrm{MgCl}_{2}$ Eutectic; Loop L-6 } \\
\hline 2 & 355.6 & 500 & 205 & $<10$ & $<10$ \\
\hline 3 & 420.4 & 555 & 145 & 13 & $<10$ \\
\hline 4 & 587.7 & 645 & 150 & 19 & 21 \\
\hline 5 & 756.2 & 880 & 196 & 18 & $<10$ \\
\hline 6 & 924.4 & 650 & 287 & 17 & $<10$ \\
\hline 7 & 1092.7 & 465 & 365 & 19 & 10 \\
\hline 8 & 1212.5 & 475 & 246 & 22 & $<10$ \\
\hline 9 & 1212.5 & 445 & 338 & 24 & $<10$ \\
\hline 10 & 1429.3 & 650 & 223 & 33 & $<10$ \\
\hline
\end{tabular}

Sample Time, hr Fe,ppm Cr, ppm $\quad$ Mn, ppm Ni, ppm Corrodent: $\mathrm{NaCl}-\mathrm{KCl}-\mathrm{MgCl}_{2}$ Eutectic; Loop L-6 (continued)

\begin{tabular}{rlrrrr}
\hline 11 & 1601 & $\approx 2000$ & 485 & 32 & 21 \\
12 & 1787 & 980 & 525 & 32 & $<10$ \\
13 & 1908.3 & 710 & 570 & 36 & $<10$ \\
14 & 2102 & 610 & $\approx 600$ & 37 & ND \\
15 & 2268.6 & 680 & 700 & 46 & 34 \\
16 & 2435.3 & 650 & $\approx 630$ & 44 & ND \\
17 & 2603.2 & 760 & $\approx 750$ & 54 & ND \\
18 & 2770.9 & 710 & $\approx 750$ & 60 & ND \\
19 & 2945 & 620 & $\approx 805$ & 65 & ND \\
20 & 3203.5 & 440 & $1000-1500$ & 62 & ND \\
21 & 3276 & 440 & $1000-1500$ & 62 & $<10$ \\
22 & 3446.1 & 415 & $1000-1500$ & 73 & 21 \\
23 & 3900 & 130 & $1000-1500$ & 81 & $<10$ \\
\hline
\end{tabular}

Corrodent: NaCl-KCl-MgCl ${ }_{2}$ Eutectic; Loop L-7

\begin{tabular}{|c|c|c|c|c|c|}
\hline 1 & 19.0 & 84 & ND & ND & ND \\
\hline 2 & 67.5 & 116 & ND & ND & ND \\
\hline 3 & 139.5 & 136 & ND & ND & ND \\
\hline 4 & 210.2 & 194 & ND & ND & ND \\
\hline 5 & 306.3 & 310 & ND & ND & ND \\
\hline 6 & 378.1 & 750 & ND & ND & ND \\
\hline 7 & 474.2 & 193 & ND & ND & ND \\
\hline 8 & 710.9 & 620 & 44 & $<10$ & ND \\
\hline 9 & 779.4 & $\approx 1350$ & 31 & $<10$ & ND \\
\hline 10 & 874.7 & 700 & 35 & $<10$ & ND \\
\hline 11 & 972.5 & 690 & 40 & 10 & ND \\
\hline 12 & 1044.0 & 760 & 51 & 32 & ND \\
\hline 13 & 1211.0 & 640 & $<10$ & $<10$ & ND \\
\hline 14 & 1235.4 & 700 & 34 & 11 & ND \\
\hline 15 & 1282.4 & 570 & 26 & $<10$ & ND \\
\hline 16 & 1456.0 & 1030 & 51 & 16 & ND \\
\hline 17 & 1477.1 & 1300 & 63 & 14 & ND \\
\hline 18 & 1548.0 & 1230 & 66 & 17 & ND \\
\hline 19 & 1619.0 & 1200 & 66 & 15 & $<10$ \\
\hline 20 & 1715.9 & 1350 & 89 & 16 & $<10$ \\
\hline 21 & 1787.7 & 1380 & 90 & 21 & $\mathrm{ND}$ \\
\hline 22 & 1884.9 & 1450 & 100 & 21 & ND \\
\hline 23 & 1960.0 & 1320 & 102 & 19 & ND \\
\hline 24 & 2058.1 & 1530 & 103 & 25 & ND \\
\hline 25 & 2125.5 & 1600 & 137 & 27 & ND \\
\hline 26 & 2218.9 & 1500 & 146 & 30 & ND \\
\hline 27 & 2297.0 & 1300 & 112 & 31 & ND \\
\hline 28 & 2392.2 & 1360 & 134 & 37 & ND \\
\hline 29 & 2463.5 & 1450 & 147 & 36 & ND \\
\hline 30 & 2555.4 & 1590 & 162 & 49 & ND \\
\hline 31 & 2723.6 & 1380 & 223 & 49 & ND \\
\hline 32 & 2893.4 & 2100 & 600 & 84 & $<10$ \\
\hline
\end{tabular}


Sample Time, hr Fe, ppm Cr, ppm $\quad$ Mn, ppm Ni, ppm

Corrodent: $\mathrm{NaCl}-\mathrm{KCl}-\mathrm{MgCl}_{2}$ Eutectic; Loop L-7 (continued)

\begin{tabular}{rrrrrr}
\hline 33 & 2965.0 & 1560 & $>2000$ & 360 & 64 \\
34 & 3060.0 & 1460 & 470 & 94 & 12 \\
35 & 3138.3 & 1310 & 615 & 136 & $<10$ \\
36 & 3269.0 & 1430 & 555 & 132 & $<10$ \\
37 & 3315.3 & 1420 & 510 & 126 & $<10$ \\
38 & 3379.5 & 1500 & 500 & 143 & $<10$ \\
39 & 3449.9 & 1420 & 560 & 146 & $<10$ \\
40 & 3548.2 & 1460 & 565 & 142 & $<10$ \\
41 & 3622.3 & 1490 & 395 & 61 & - \\
42 & 3716.0 & 1340 & 445 & 65 & - \\
43 & 3787.2 & 1490 & 410 & 66 & - \\
44 & 3916.1 & 1460 & 412 & 74 & - \\
45 & 3956.3 & 1470 & 395 & 70 & - \\
46 & 4078.5 & 1460 & 335 & 72 & - \\
47 & 4123.1 & - & - & 72 & $<10$ \\
48 & 4222.9 & 1600 & 357 & 82 & 15 \\
49 & 4290.0 & 1600 & 339 & 78 & $<10$ \\
50 & 4387.2 & & insufficient sample & \\
51 & 4461.9 & 1600 & 402 & 98 & $<10$ \\
52 & 4555.1 & 1700 & 403 & 92 & $<10$ \\
53 & 4627.8 & & insufficient sample & \\
54 & 4723.2 & 1620 & 373 & 89 & $<10$ \\
55 & 4794.8 & 1600 & 378 & 87 & $<10$ \\
56 & 4890.2 & 1700 & 395 & 91 & $<10$ \\
57 & 4977.0 & 1730 & 365 & 86 & $<10$ \\
58 & 5057.8 & 1740 & 383 & 90 & $<10$ \\
59 & 5129.9 & 1770 & 378 & 87 & $<10$ \\
60 & 5225.8 & 1780 & 433 & - & $<10$ \\
61 & 5297.9 & 1750 & 373 & 84 & $<10$ \\
\hline
\end{tabular}

Sample Time, hr Fe, ppm Cr, ppm Mn, ppm Ni, ppm

Corrodent: $\mathrm{NaCl}-\mathrm{KCl}-\mathrm{MgCl}_{2}$ Eutectic; Loop L-7 (continued)

\begin{tabular}{llllrl}
\hline 62 & 5394.0 & 1730 & 403 & 96 & $<10$ \\
63 & 5561.2 & 1730 & 413 & 95 & $<10$ \\
64 & 5632.9 & 1760 & 377 & 94 & $<10$ \\
65 & 5728.9 & 1730 & 413 & 97 & $<10$ \\
66 & 5801.0 & 1770 & 395 & 98 & $<10$ \\
67 & 5897.5 & 1780 & 445 & 92 & $<10$ \\
68 & 5973.4 & 2080 & 411 & 94 & $<10$ \\
69 & 6066.8 & 2040 & 390 & 93 & $<10$ \\
70 & 6140.6 & 2160 & 405 & 95 & $<10$ \\
71 & 6237.0 & 2070 & 419 & 100 & $<10$ \\
72 & 6280.8 & 2120 & 420 & 98 & $<10$
\end{tabular}

Corrodent: NaCl-KCl- $\mathrm{MgCl}_{2}$ Eutectic; Loop M*

\begin{tabular}{crrrrr}
\hline Initial & - & 21 & 23 & 10 & 10 \\
1 & 24.9 & 28 & 69 & 10 & $<10$ \\
2 & 258.7 & 210 & 105 & 10 & 11 \\
3 & 582.4 & 320 & 94 & 18 & 10 \\
4 & 654.3 & 1375 & 180 & 23 & 20 \\
5 & 752.8 & 415 & 122 & 16 & 16 \\
6 & 796.4 & 720 & 180 & 14 & $<10$ \\
10 & 916.9 & 440 & 131 & 18 & $<10$ \\
11 & 1034.0 & 185 & 143 & 20 & $<10$ \\
$12^{* *}$ & 1034.0 & $\approx 1700$ & 135 & 24 & 11 \\
\hline
\end{tabular}

*For Loop M, time represents pump hours. The initial sample was taken from the pretreatment tank, all other samples from the surge tank.

**Filtered sample. 